\title{
Aromatic and heterocyclic perfluoroalkyl sulfides. Methods of preparation
}

\author{
Vladimir N. Boiko
}

\section{Review}

\section{Address:}

Institute of Organic Chemistry, National Academy of Sciences of Ukraine, Murmanskaya St. 5, 02094 Kiev, Ukraine

\section{Email:}

Vladimir N. Boiko - boikovolodymyr@yandex.ru

Keywords:

halex-process; perfluoroalkylation; perfluoroalkyl sulfides;

$\mathrm{SR}_{\mathrm{F}}$-introduction

\author{
Beilstein J. Org. Chem. 2010, 6, 880-921. \\ doi:10.3762/bjoc. 6.88 \\ Received: 09 March 2010 \\ Accepted: 16 July 2010 \\ Published: 18 August 2010 \\ Guest Editor: D. O’Hagan \\ (C) 2010 Boiko; licensee Beilstein-Institut. \\ License and terms: see end of document.
}

\begin{abstract}
This review covers all of the common methods for the syntheses of aromatic and heterocyclic perfluoroalkyl sulfides, a class of compounds which is finding increasing application as starting materials for the preparation of agrochemicals, pharmaceutical products and, more generally, fine chemicals. A systematic approach is taken depending on the mode of incorporation of the $\mathrm{SR}_{\mathrm{F}}$ groups and also on the type of reagents used.
\end{abstract}

\section{Review}

\section{Introduction}

Perfluoroalkyl sulfides of aromatic and heterocyclic compounds have been an important aspect in the general development of organofluorine chemistry over the last twenty years.

Alkyl aryl sulfides containing partly fluorinated aliphatic moieties have been widely used for a number of years. Their methods of preparation, for example, by the reaction of thiols with fluoro-olefins or with chloropolyfluoroalkanes are well known and have been widely used. In contrast, sulfides with fully fluorinated aliphatic chains have been limited to trifluoromethylated compounds. This was due to the unique preparation (at that time) of such compounds by means of two consecutive reaction steps: the chlorination of the side chain followed by replacement of the chlorine atoms by fluorine. This procedure enabled only the preparation of $\mathrm{CF}_{3} \mathrm{~S}$-derivatives because it is

not possible to synthesize perchloroalkylated aromatic sulfides larger than $\mathrm{CCl}_{3} \mathrm{~S}$. This is currently still the case. Iodoperfluoroalkanes as perfluoroalkylating agents have only emerged rather recently.

New synthetic procedures to access this class of compounds have appeared which make use of novel intermediates. Thus, single-electron oxidation or reduction enables the generation of perfluoroalkyl radicals. Two-electron reduction of perfluoroalkyl iodides generates perfluoroalkyl carbanions, which may be stabilized by organophosphorus and organosilicon ligands and even by dimethylformamide.

One of the driving forces for the synthesis of perfluoroalkyl sulphides is the high lipophilic properties of perfluoroalkylthio 
<smiles></smiles>

coccidiostatics $n=0$ Toltrazuril<smiles>N#Cc1nn(-c2c(Cl)cc(C(F)(F)F)cc2Cl)c(N)c1[GeH2]OC(F)(F)F</smiles>

insecticides $n=1$ Fipronil<smiles>CN1Sc2cc(OS(N)(=O)=O)c(Cl)cc2NC1CSCC(F)(F)F</smiles>

Polythyazid

antihypertensive, diuretic

Figure 1: Examples of industrial fluorine-containing bio-active molecules.

groups (the greatest Hansch constant $\pi=1.44$, belongs to $\mathrm{SCF}_{3}$ group [1]), which increases the ability of such molecules to cross lipid membranes and creates opportunities for the modification of known and new drugs. Thus this group is a useful substituent in agrochemicals and pharmaceuticals [2-4]. Examples of bioactive compounds containing $\mathrm{SCF}_{3}, \mathrm{SOCF}_{3}$ and $\mathrm{SO}_{2} \mathrm{CF}_{3}$ groups are shown in Figure 1 and Figure 2.

The synthesis of a large number of potential hypotensive agents containing $\mathrm{SR}_{\mathrm{F}}$ and $\mathrm{SO}_{2} \mathrm{R}_{\mathrm{F}}$ groups of the 1,4-dihydropyridine class and also of Losartan (Dup 753) analogues which are used clinically for the treatment of cardiovascular diseases have also been developed [5,6] (Figure 3).

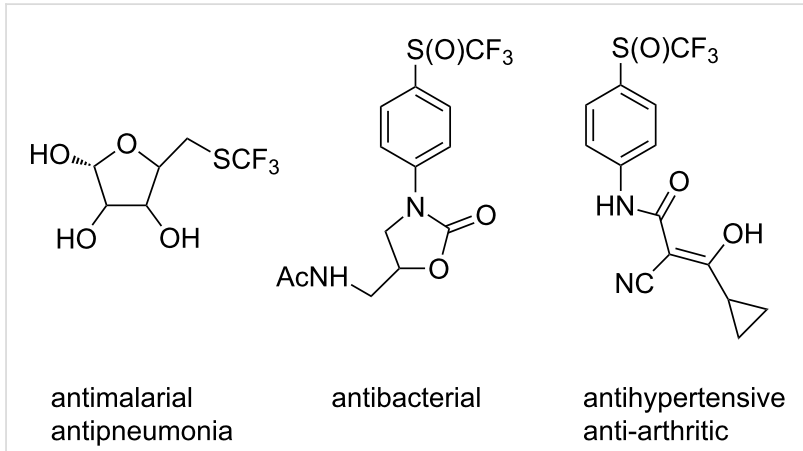

Figure 2: $\mathrm{CF}_{3}(\mathrm{~S})$ - and $\mathrm{CF}_{3}(\mathrm{O})$-containing pharmacologically active compounds.<smiles>[Y][V]=[W]</smiles>

$\mathrm{R}_{\mathrm{F}}=\mathrm{CF}_{3}, \mathrm{CF}_{2} \mathrm{CHF}_{2}$

anti-inflammatory\footnotetext{
<smiles>[R]c1ccc2c(c1)nc([R])n2Cc1ccc(-c2ccccc2-c2nnn[nH]2)cc1</smiles>

Losartan analogues
$\mathrm{R}=\mathrm{C}_{4} \mathrm{H}_{9} ; \mathrm{R}^{\prime}=\mathrm{SCF}_{3}, \mathrm{SC}_{2} \mathrm{~F}_{5}, \mathrm{SC}_{3} \mathrm{~F}_{7}, \mathrm{OC}_{2} \mathrm{~F}_{5}, \mathrm{SO}_{2} \mathrm{C}_{3} \mathrm{~F}_{7}$
$\mathrm{R}=\mathrm{SC}_{2} \mathrm{~F}_{5}, \mathrm{SC}_{3} \mathrm{~F}_{7}, \mathrm{SC}_{4} \mathrm{~F}_{9} ; \mathrm{R}^{\prime}=\mathrm{H}^{2}$

Losartan analogues
$\mathrm{R}=\mathrm{C}_{4} \mathrm{H}_{9} ; \mathrm{R}^{\prime}=\mathrm{SCF}_{3}, \mathrm{SC}_{2} \mathrm{~F}_{5}, \mathrm{SC}_{3} \mathrm{~F}_{7}, \mathrm{OC}_{2} \mathrm{~F}_{5}, \mathrm{SO}_{2} \mathrm{C}_{3} \mathrm{~F}_{7}$
$\mathrm{R}=\mathrm{SC}_{2} \mathrm{~F}_{5}, \mathrm{SC}_{3} \mathrm{~F}_{7}, \mathrm{SC}_{4} \mathrm{~F}_{9} ; \mathrm{R}^{\prime}=\mathrm{H}^{2}$

Losartan analogues
$\mathrm{R}=\mathrm{C}_{4} \mathrm{H}_{9} ; \mathrm{R}^{\prime}=\mathrm{SCF}_{3}, \mathrm{SC}_{2} \mathrm{~F}_{5}, \mathrm{SC}_{3} \mathrm{~F}_{7}, \mathrm{OC}_{2} \mathrm{~F}_{5}, \mathrm{SO}_{2} \mathrm{C}_{3} \mathrm{~F}_{7}$
$\mathrm{R}=\mathrm{SC}_{2} \mathrm{~F}_{5}, \mathrm{SC}_{3} \mathrm{~F}_{7}, \mathrm{SC}_{4} \mathrm{~F}_{9} ; \mathrm{R}^{\prime}=\mathrm{H}^{2}$
} 
Other patented compounds containing perfluoroalkyl thio substituents are illustrated in Figure 4 and Figure 5 along with their pharmacological functions [7-11].

These examples represent only a small number of the vast array of organic compounds with $\mathrm{SR}_{\mathrm{F}}, \mathrm{SOR}_{\mathrm{F}}$ or $\mathrm{SO}_{2} \mathrm{R}_{\mathrm{F}}$ groups which display pharmacological activity and interest in such analogues continues to grow.

Previous reviews in this area are either dated [19] or focus on specialist aspects such as perfluoroalkyl radicals [20-22], fluorinated carbanions [23], organometallic compounds [24,25], per-<smiles>[R]c1ccc(C2CN(C(=O)OC(F)(F)F)CCc3cc([Si](C)(F)F)c(OC)cc32)cc1</smiles>

potential antigastritis facilities<smiles>CC(=O)Nc1ccc(F)cc1</smiles>

$\mathrm{R}_{\mathrm{F}}=\mathrm{CF}_{3}, \mathrm{C}_{3} \mathrm{~F}_{7}$

regulators of plants growth, fungicides, herbicides<smiles>[R7]c1n[nH]c(=O)[nH]c1=O</smiles>

anticoccidial<smiles>COc1ccc2c(C(=S)N(C)CC(C)=O)cccc2c1S(F)(F)(F)(F)F</smiles>

diabetes mellitus treatment

Figure 4: The variety of the pharmacological activity of $\mathrm{R}_{\mathrm{F}} \mathrm{S}$-substituted compounds.

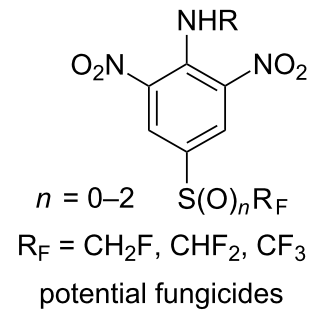<smiles>[R]n1c(=O)sc2ccc(C(=O)NCc3ccccc3)cc2c1=O</smiles>

arthritis treatment<smiles></smiles>

$\mathrm{X}=\mathrm{NH}, \mathrm{O}, \mathrm{S}$

protein vanilloid receptor 1 activity<smiles>O=c1[nH]c(-c2ccc(OCc3sc(-c4ccc([AlH])cc4)nc3C(F)(F)F)cc2)no1</smiles>

agonists of peroxisoma receptor

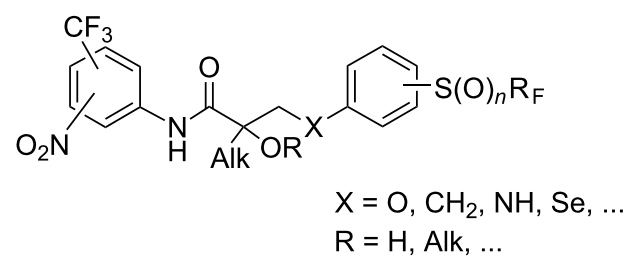

selective modulators of androgenic receptors<smiles>[X][X]c1ccc(C(=O)Nc2ccc(C)c(Nc3nccc(-c4cccnc4)n3)c2)cc1</smiles>

therapy of chronic myeloid leukemia 
fluoroalkyl sulfenyl halides [26], perfluoroalkyl silicon reagents [27-32], the trifluoromethylthio anion [29] or electrophilic perfluoroalkylating agents [33]. Others are devoted to particular methods such as trifluoromethylation initiated by sodium dithionite [34] or the electrochemical introduction of fluoroalkyl groups in organic molecules [35]. Moreover, many of the reviews on the subject are very general $[28,30,32,36]$.

The present work reviews synthetic methods employed to prepare aromatic and heterocyclic perfluoroalkyl sulfides and is systematized depending on the mode of constructing the $\mathrm{SR}_{\mathrm{F}}$ groups and also on the nature of the starting materials.

1. The halogenation of SAlk-derivatives with subsequent replacement of the halogen atoms by fluorine.

2. The introduction of $\mathrm{SR}_{\mathrm{F}}$-moieties into aromatic compounds by both electrophilic and nucleophilic reagents.

3. Various modes of perfluoroalkylation of organosulfur compounds including cationic, anionic, radical and ionradical variants.

\section{Substitution of halogen atoms by fluorine in aryl-a-polyhalogenoalkyl sulfides}

Substitution of the halogen atoms in $\mathrm{SAlk}_{\mathrm{Hlg}}$ groups (mainly chlorine) using antimony trifluoride [37], is the oldest method of perfluoroalkylsulfide preparation and is still commercially significant.

The reaction is carried out by heating a mixture of aryl trichloromethyl sulfide with an excess of $\mathrm{SbF}_{3}$ in the absence of a solvent. For industrial processes, dry hydrogen fluoride is used as the fluorinating agent (Scheme 1).

The presence of halogen atoms and electron-withdrawing groups such as $\mathrm{NO}_{2}, \mathrm{CF}_{3}$ or $\mathrm{COCl}$ in the aromatic ring of trichlorothioanisole does not influence the fluorination and the reaction is not hindered by bulky ortho-substituents e.g., phthalic acid imide [53] or $N$-substituted anilines [54]. Other reactive substituents, for example $3-\mathrm{SCCl}_{3}$ or $4-\mathrm{COCl}$ are also fluorinated and form 1,3-bis $\left(\mathrm{SCF}_{3}\right)$ benzene [38-40] and 4- $\mathrm{SCF}_{3}$-benzoic acid fluoride, respectively [55].

The use of hydrogen fluoride has some advantages. Due to its low boiling point $\left(+19.4{ }^{\circ} \mathrm{C}\right)$ and good solubility in water,

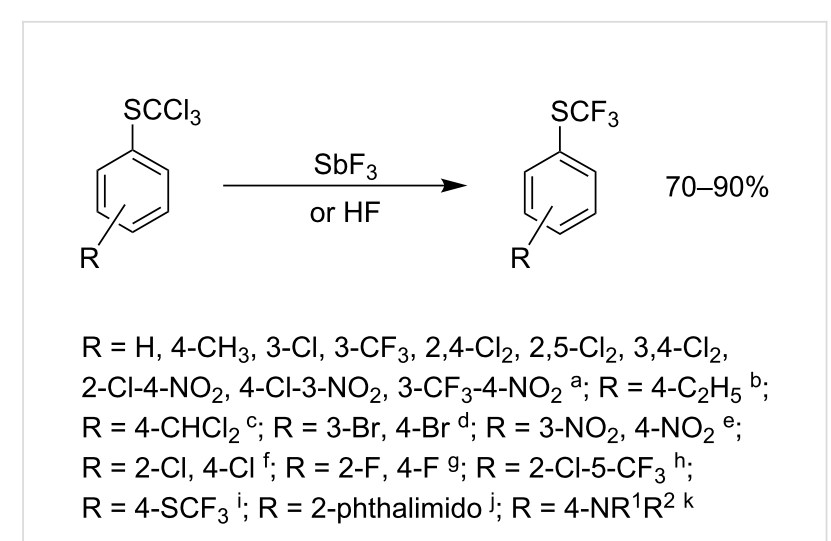

Scheme 1: Fluorination of $\mathrm{ArSCCl}_{3}$ to corresponding $\mathrm{ArSCF}_{3}$ derivatives. For references see: a[38-43]; b $[41,42]$; ' $[43]$; ${ }^{d}[44]$; e[38-43,45-

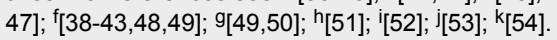

excess $\mathrm{HF}$ is easily removed from the reaction mixture. Unlike $\mathrm{HF}$, reactions with $\mathrm{SbF}_{3}$ can be carried out in glass. The $\mathrm{SbF}_{3}$ must be freshly sublimed and used in a corrosion-proof vessel. Attempts to use less aggressive fluoride ion sources, e.g., $\mathrm{KF} /$ 18-Crown-6 in $\mathrm{CH}_{3} \mathrm{CN}$ or $\mathrm{KF} / \mathrm{Bu}_{4} \mathrm{~N}^{+} \mathrm{Cl}^{-}$under phase-transfer conditions, have been unsuccessful [56].

The method does not give access to longer perfluoroalkyl sulfides because the required aryl perchloroalkyl sulfide precursors are not easily accessible [57,58]. However, pentafluoroethyl ethers of various thiophenols (or phenols) can be obtained by the more sequential process as shown in Scheme 2 [59].

Use of mixed $(\mathrm{Cl} / \mathrm{F})$ polyhalogenofluoro alkanes as partial fluorinated alkylating agents generates the corresponding sulfides which are appropriate precursors for subsequent conversion to perfluoroalkyl thioethers. For example, $\alpha, \alpha-$ difluoro polyhalogenoalkyl sulfides and $\alpha, \alpha$-dichlorotrifluoroethyl sulfide can be obtained by reaction of thiophenols with dihalogenodifluoro methanes [60-62], per(halogenofluoro) ethanes $[60,63,64]$ and 2,2,2-trifluorotrichloroethane.

The Cl- and Br-substituents can then be replaced by fluorine without use of $\mathrm{HF}$ or $\mathrm{SbF}_{3}$ [61]. As shown in Scheme 3 [65], bromine to fluorine exchange is possible by the use of other heavy metal fluorides, and even by silver tetrafluoroborate under mild conditions.

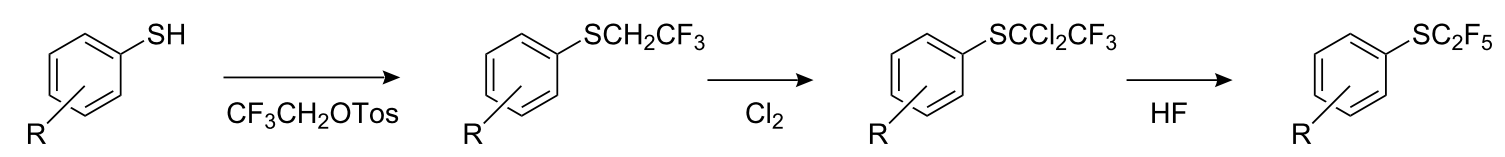




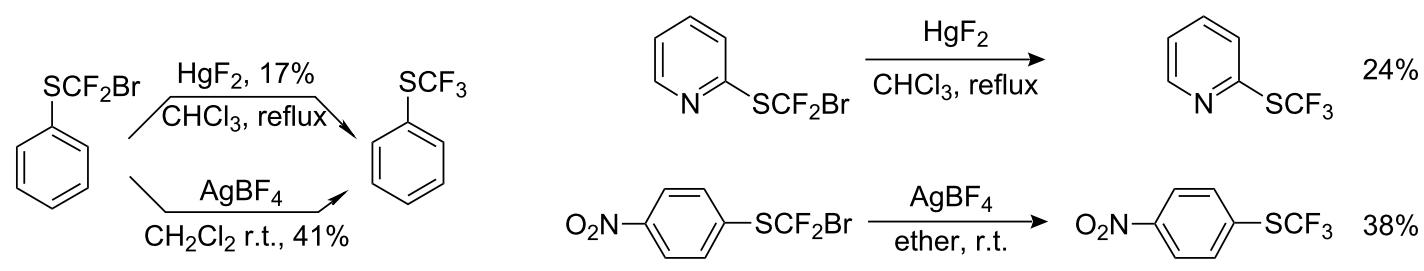

Scheme 3: Mild fluorination of the aryl $\mathrm{SCF}_{2} \mathrm{Br}$ derivatives.

The halex-method allows the selective preparation of $\alpha, \alpha$-difluoroalkyl aryl sulfides (and also ethers, sulfoxides and sulfones) as intermediate products in the synthesis of herbicides $[66,67]$. Interestingly, the reaction of anhydrous hydrogen fluoride with aryl $\alpha, \alpha, \beta$-trichloroisobutyl sulfide at $20{ }^{\circ} \mathrm{C}$ leads only to substitution of the $\alpha$-chlorine atoms, whilst at a higher temperature and pressure a more complete fluorination with rearrangement is observed [67] (Scheme 4).

Hydrogen fluoride/fluoride complexes such as $\mathrm{H}_{2} \mathrm{~F}_{3}$ stabilized on a polymer [68] show even greater selectivity. For example, only one chlorine atom of the $\alpha, \alpha$-dichloromethylene group of benzyl alkyl sulfide is substituted by the reagent (Scheme 5).

\section{$\mathrm{PhCH}_{2} \mathrm{SCCl}_{2} \mathrm{COOMe} \stackrel{\mathrm{H}_{2} \mathrm{~F}_{3} \text { /polymer }}{\longrightarrow} \mathrm{PhCH}_{2} \mathrm{SCFCICOOMe}$}

Scheme 5: Monofluorination of a,a-dichloromethylene group.

Thus, halogen atoms replacement by fluorine is an effective and cheap method for preparing aromatic and heterocyclic perfluoroalkyl sulfides. Application of the appropriate conditions allows control and a degree of selectivity thus making this method an important industrial process.

\section{Introduction of the aryl $\mathrm{SR}_{\mathrm{F}}$ moiety}

\subsection{Electrophilic introduction of $\mathrm{SR}_{\mathrm{F}}$ groups}

Perfluoroalkyl sulfenyl chlorides react with electron rich aromatic and heterocyclic compounds, to give $\mathrm{SR}_{\mathrm{F}}$ derivatives.
Thus, phenol, $o$-hydroquinone and their derivatives react with $\mathrm{CF}_{3} \mathrm{SCl}$ to yield $p$-hydroxyaryl trifluoromethyl sulfides (Scheme 6).

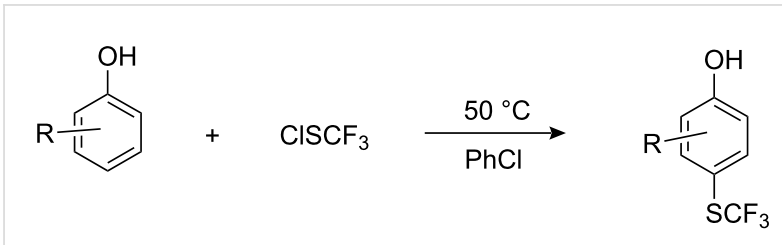

$\mathrm{R}=\mathrm{H}(26 \%), 2-\mathrm{OH}(54 \%), 2-\mathrm{Me}(53 \%), 3-\mathrm{Me}(67 \%), 3-\mathrm{Cl}(42 \%)$

Scheme 6: Electrophilic substitution of phenols with $\mathrm{CF}_{3} \mathrm{SCl}$ [69].

The best yields are achieved when electron-donating substituents are present on the ring. In the case of $m$-cresol and $m$-chlorophenol a small degree of $o$-substitution was observed. Phenol is a poor substrate in the reaction (Scheme 6) however, when $\mathrm{FeCl}_{3}$ was used as a catalyst the yield of $p-\mathrm{HOC}_{6} \mathrm{H}_{4} \mathrm{SCF}_{3}$ was increased, albeit only slightly (30\%). A significant improvement in yield occurs $(72 \%)$ when the reaction is conducted with pyridine in chloroform and at ambient temperatures $\left(0-20^{\circ} \mathrm{C}\right)[70,71]$. Under these conditions and with electron-donating substituents in the phenol, two and even three perfluoroalkylthio groups can be introduced (Scheme 7).

Forcing conditions are required for the introduction of three $\mathrm{CF}_{3} \mathrm{~S}$-groups. This can be achieved either by activation with iron powder under pressure (or by conduction the reaction in a<smiles>CC(C)(Cl)c1ccc(Cl)cc1</smiles><smiles>CCCCCC</smiles><smiles>CC(C)(Cl)[GeH2]c1ccc(Cl)cc1</smiles><smiles>CC(C)(C)Sc1ccc(Cl)cc1</smiles> 


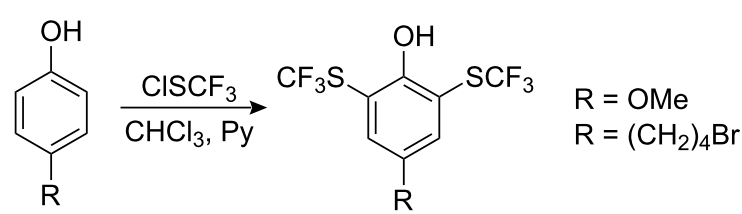

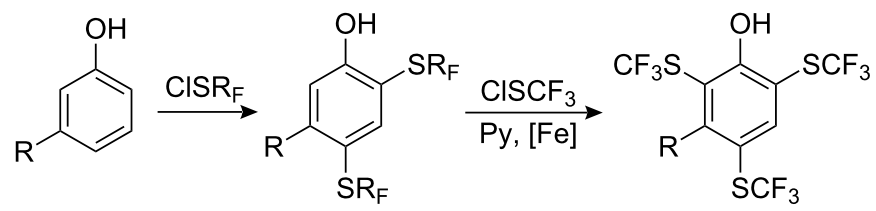

$$
\begin{aligned}
& \mathrm{R}=\mathrm{OH}, \mathrm{OCH}_{3} \\
& \mathrm{R}_{\mathrm{F}}=\mathrm{CF}_{3}, \mathrm{C}_{7} \mathrm{~F}_{15}
\end{aligned}
$$<smiles>[R]c1cc([R])cc(O)c1</smiles>

$\mathrm{R}^{\prime}=\mathrm{OH}, \mathrm{OCH}_{3}, \mathrm{CH}_{3}$

Scheme 7: Introduction of $\mathrm{SCF}_{3}$ groups into activated phenols [71-74].

steel autoclave) or by the presence of two donor groups in metapositions [71].

For $p$-hydroquinone, reaction with $\mathrm{CF}_{3} \mathrm{SCl}$ in the presence of pyridine results only in the formation of a chlorohydroquinone pyridinium species [72], and neutral conditions are required in this case [69]. For the synthesis of poly $\left(\mathrm{SCF}_{3}\right)$ substituted $p$-hydroquinones, Scribner oxidized 2,6-bis $\left(\mathrm{SCF}_{3}\right)$-4methoxyphenol to generate 2,6-bis $\left(\mathrm{SCF}_{3}\right)$-1,4-benzoquinone. The addition of $\mathrm{CF}_{3} \mathrm{SH}$ in the presence of pyridine to the biscompound gave 2,3,5-tris $\left(\mathrm{SCF}_{3}\right)$ hydroquinone [72] which could be subsequently converted into tetrakis $\left(\mathrm{SCF}_{3}\right)$-1,4-hydroquinone (Scheme 8).

Unlike $p$-hydroquinone, resorcinols and phloroglucinols perhaps surprisingly react with $\mathrm{R}_{\mathrm{F}} \mathrm{SCl}$ [75] to generate monoperfluoroalkyl thio derivatives. With iron powder as a catalyst bis $\left(\mathrm{SR}_{\mathrm{F}}\right)$-derivatives can be obtained (Scheme 9).
Similarly, methyl benzoates and benzaldehydes with two and especially three hydroxyl groups form bis $\left(\mathrm{CF}_{3} \mathrm{~S}\right)$-substituted derivatives without of catalyst.

Analogous reactions are observed with aniline. However, since reaction takes place in the first instance on the amino group $[74,76]$, for the introduction of $\mathrm{SCF}_{3}$ group into the aromatic ring the amino function must be protected. Mono- $N$-substitution is insufficient: $N$-methyl aniline, $N$-( $\left.\mathrm{SCF}_{3}\right)$ aniline and $N(\mathrm{Ac})$ - $m$-toluidine all yield mainly $N$-( $\left.\mathrm{SCF}_{3}\right)$-derivatives, and only a small amount of aromatic $\mathrm{CF}_{3} \mathrm{~S}$-substitution is observed [74]. The best results are achieved [70,74] with $N, N$-bis-substituted aniline (Scheme 10).

The introduction of strong electron-donating meta groups significantly activates the aromatic nuclei not only for $N, N$-bissubstituted anilines but also for $\mathrm{N}$-monosubstituted substrates and even those with a free $\mathrm{NH}_{2}$ group (Scheme 11).

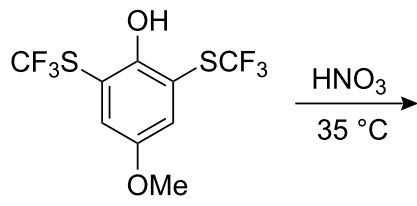<smiles></smiles>

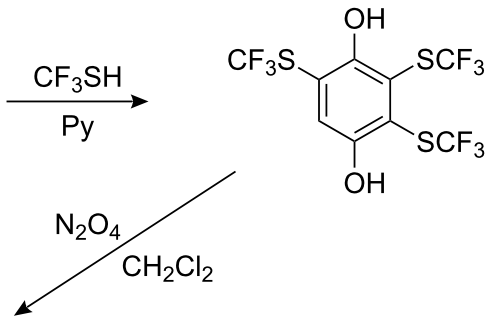<smiles>O=C1C=C(SC(F)(F)F)C(=O)C([As]C(F)(F)F)=C1C(F)(F)F</smiles>

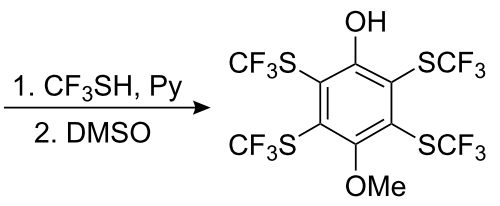




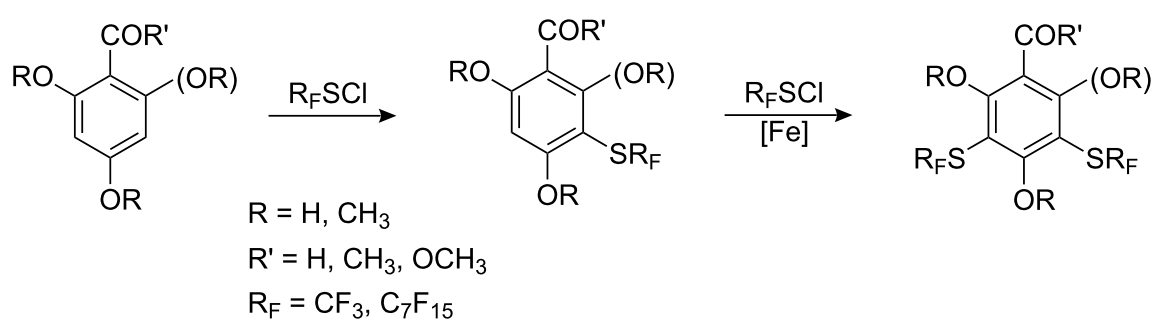

Scheme 9: The interactions of resorcinol and phloroglucinol derivatives with $\mathrm{R}_{\mathrm{F}} \mathrm{SCl}$.

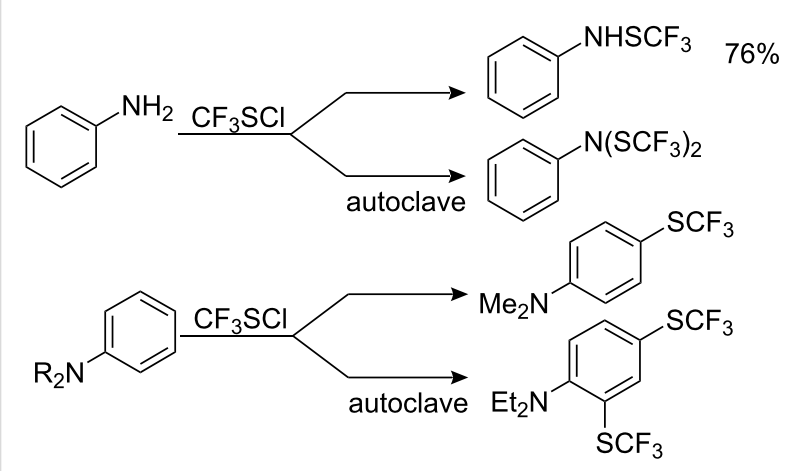

Scheme 10: Reactions of anilines with $\mathrm{CF}_{3} \mathrm{SCl}$

In naphthalene and benzophenone derivatives only those rings containing hydroxy or amino groups undergo perfluoroalkylsulfanylation $[74,75]$. Other electron-donating substituents on the aromatic ring are not so activating for reaction with $\mathrm{CF}_{3} \mathrm{SCl}$. For example, thiophenol [76] forms only phenyltrifluoromethyl disulfide [70]. The presence of a methyl group and halogens requires high temperatures $\left(100-200{ }^{\circ} \mathrm{C}\right)$ and the presence of catalysts $\left(\mathrm{HF}\right.$ or $\left.\mathrm{BF}_{3}\right)$ for reaction and yields of the corres- ponding aryltrifluoromethyl sulfides are only $25-60 \%$. Both toluene and halobenzenes lead to mixtures of isomers [70].

Benzene undergoes trifluoromethylsulfanylation with trifluoromethanesulfonic acid as a catalyst even at $20{ }^{\circ} \mathrm{C}$. However, further reaction of the resultant phenyltrifluoromethyl sulfide leads mainly to chlorination with only minor amounts of bis$\left(\mathrm{CF}_{3} \mathrm{~S}\right)$ products (Scheme 12).

Aryl magnesium [78] and -mercury [79] compounds have been employed for the introduction of $\mathrm{CF}_{3} \mathrm{~S}$ groups. Such reactions proceed in ether or THF at low temperatures; however, the yields of aryltrifluoromethyl sulfides do not exceed 50-60\% and are accompanied with halogenated side-products (Scheme 13).

Among heterocyclic systems, pyrroles are the best substrates for reaction with trifluoromethyl-, difluorochloro- and dichlorofluoromethyl sulfenyl chlorides. Their reactivity exceeds that of benzene and its organometallic derivatives [80]. An excess of reagent gives bis- $\left(\mathrm{SCF}_{3}\right)$ pyrrole derivatives as shown in Scheme 14.<smiles>CN(C)c1cccc(O)c1</smiles><smiles>[R]Nc1cccc([X])c1</smiles><smiles>Cc1cccc(N)c1</smiles>

$\mathrm{R}=\mathrm{CH}_{2} \mathrm{CF}_{3}, \mathrm{COCH}_{3}, \mathrm{SO}_{2} \mathrm{CF}_{3}$ $\mathrm{Z}=\mathrm{S}, \mathrm{O}$

$\mathrm{X}=\mathrm{OH}, \mathrm{OMe}, \mathrm{OCH}_{2} \mathrm{CF}_{3}, \mathrm{NHCH}_{2} \mathrm{CF}_{3}$ 


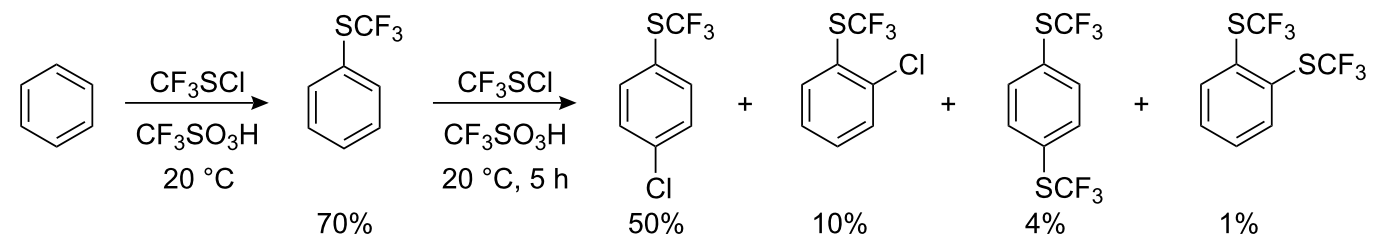

Scheme 12: Reaction of benzene with $\mathrm{CF}_{3} \mathrm{SCl}_{/} \mathrm{CF}_{3} \mathrm{SO}_{3} \mathrm{H}$ [77]

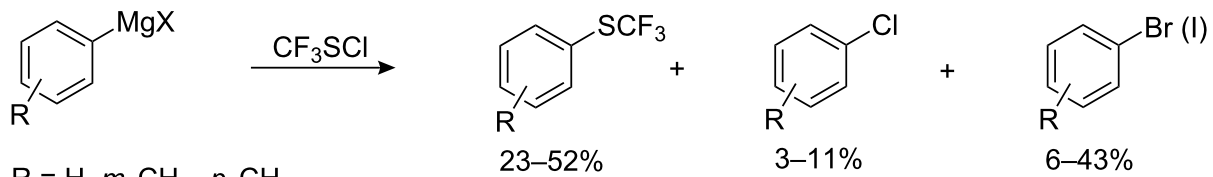

$\mathrm{R}=\mathrm{H}, m-\mathrm{CH}_{3}, p-\mathrm{CH}_{3}$

$\mathrm{X}=\mathrm{Cl}, \mathrm{Br}, \mathrm{I}$

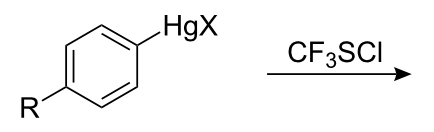

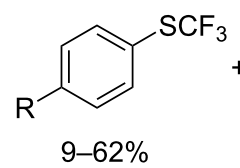<smiles>[R]c1ccc(Cl)cc1</smiles><smiles>[R]c1ccccc1</smiles>

$\mathrm{R}=\mathrm{H}, \mathrm{CH}_{3}, \mathrm{OCH}_{3}, \mathrm{Cl}, \mathrm{NO}_{2}$

$\mathrm{X}=\mathrm{Cl}, \mathrm{OCOCH}_{3}, \mathrm{OCOCF}_{3}$

Scheme 13: Reactions of trifluoromethyl sulfenyl chloride with aryl magnesium and -mercury substrates.

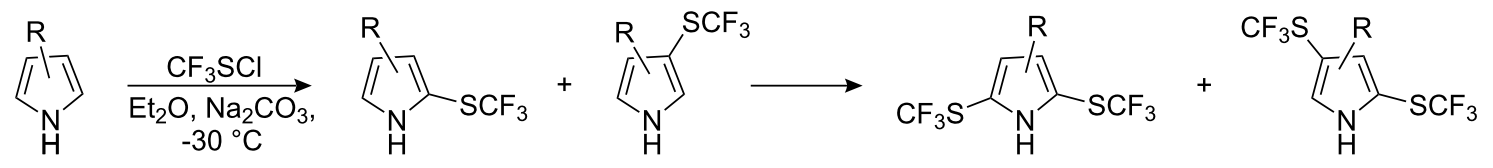

$\mathrm{R}=\mathrm{H}, 2-\mathrm{COOH}, 2-\mathrm{COMe}, 2,4-$ and $2,5-\mathrm{Me}_{2}$

Scheme 14: Reactions of pyrroles with $\mathrm{CF}_{3} \mathrm{SCl}$.

Condensed pyrroles also react readily with $\mathrm{CF}_{3} \mathrm{SCl}$. Indole undergoes substitution, as expected, at the 3-position [80], while indolizine and some of its derivatives give 1,3-bis $\left(\mathrm{SCF}_{3}\right)$-substituted products, in some cases, in quantitative yield [81]. It is interesting to note that not only hydrogen, but also an acetyl group in the 1-position is substituted (Scheme 15).

However, no reaction occurs when there are two electron-withdrawing groups in the five-membered indolizine ring (e.g. $\mathrm{R}=\mathrm{Ph}$, and $\mathrm{X}=\mathrm{COPh}$ or $\mathrm{NO}_{2}$ ). By contrast, in the case of 1-benzyl-2-methyl indolizine [81] both the pyrrole and the aromatic ring of the benzyl group undergo trifluoromethylsulfanylation. Only $\mathrm{N}$-substitution occurs in the case of carbazole [80].
$N$-Methylpyrrole can be variously substituted depending on the conditions as illustrated in Scheme 16.

Heating $\mathrm{N}$-methylpyrrole in $\mathrm{CHCl}_{3} / \mathrm{Py}$ affords the $2-\mathrm{SCF}_{3}$ derivative along with a small amount of $3-\mathrm{SCF}_{3}-N$-methylpyrrole [83]. Attempted selective introduction of the second $\mathrm{SCF}_{3}$ group at $-30{ }^{\circ} \mathrm{C}$ with $\mathrm{C}_{4} \mathrm{~F}_{9} \mathrm{SO}_{3} \mathrm{H}$ to 2-trifluoromethylsulfanylpyrrole was unsuccessful and gave a mixture of 2,4- and 2,5-isomers [87].

Unlike pyrroles, furan, thiophene and selenophene react with $\mathrm{CF}_{3} \mathrm{SCl}$ only in the presence of catalysts. For selenophene [84] and thiophenes [85] $\mathrm{SnCl}_{4}$ is sufficient, whilst furans require more forcing conditions usually involving prolonged heating 

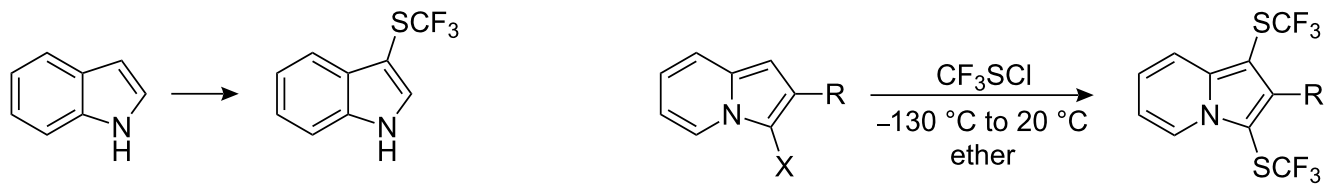

$\mathrm{R}=\mathrm{H}, \mathrm{Me}, \mathrm{Ph} ; \mathrm{X}=\mathrm{H}, \mathrm{COCH}_{3}$

Scheme 15: Trifluoromethylsulfanylation of indole and indolizines.
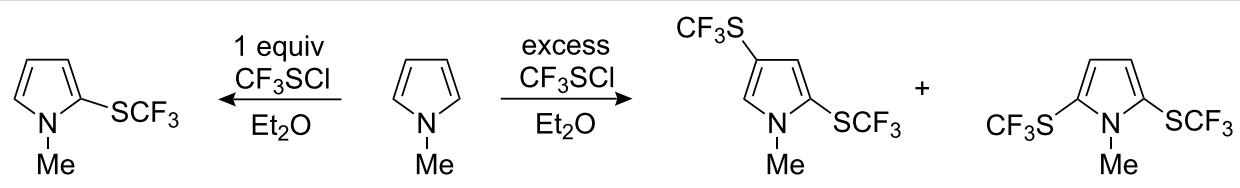

Scheme 16: Reactions of $\mathrm{N}$-methylpyrrole with $\mathrm{CF}_{3} \mathrm{SCl}[80,82]$.

$\left(20 \mathrm{~h}\right.$ at $\left.60{ }^{\circ} \mathrm{C}\right)$ and in pyridine for activation [83,84] (Scheme 17).

Similarly, some five membered heterocycles with two heteroatoms $\left[N\right.$-Ac- and $N$ - $\left(\mathrm{SO}_{2} \mathrm{Alk}\right)$-thiazoles, 1-Me-2$\mathrm{SCH}_{2} \mathrm{CF}_{3}$ - and 1,2- $\mathrm{Me}_{2}$-imidazoles] undergo single trifluoromethylsulfanylation on heating $\left(60{ }^{\circ} \mathrm{C}\right)$ with $\mathrm{CF}_{3} \mathrm{SCl}$ in a pyridine-chloroform mixture [83]. Interestingly, unlike 1,2dimethylimidazole, the sulfanylation of 2,4-dimethylthiazole under the same conditions occurs twice on the same 2-methyl group (Scheme 18).

Pyridine is too deactivated for trifluoromethylsulfanylation under classical conditions and to achieve substitution it is first of all necessary to convert pyridine to an anionic hydride $\sigma$-complex by reduction with $\mathrm{LiAlH}_{4}$ [86]. The reaction with $\mathrm{CF}_{3} \mathrm{SCl}$ then proceeds with difficulty [84] and mono-substituted 3-trifluoromethylsulfanyl pyridine is formed in low yield along with small amounts of the 3,5-bis $\left(\mathrm{SCF}_{3}\right)$ derivative $(\sim 1 \%)$ (Scheme 19).

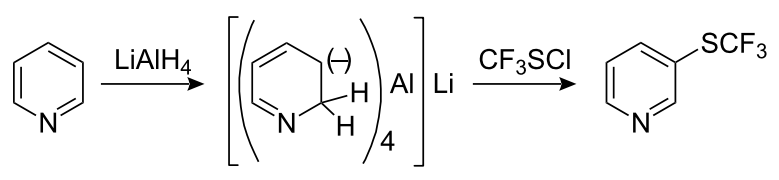

Scheme 19: Trifluoromethylsulfanylation of pyridine requires initia hydride reduction.

Introduction of additional $\mathrm{R}_{\mathrm{F}} \mathrm{S}$-groups into heterocyclic compounds (except for pyrrole and its derivatives) occurs in the presence of perfluoroalkanesulfonic acids (Scheme 20). Incorporation of the second fluoroalkylsulfanyl group into thiophenes [85] and selenophene [84] is possible in the presence of $\mathrm{CF}_{3} \mathrm{SO}_{3} \mathrm{H}$. However, reaction of $\mathrm{CF}_{3} \mathrm{SCl}$ with 2,5-bis $\left(\mathrm{SCF}_{3}\right)$ thiophene in presence of $\mathrm{CF}_{3} \mathrm{SO}_{3} \mathrm{H}$ gives the 3-chloro-derivative as the major product. 2,3,5-Tris $\left(\mathrm{SCF}_{3}\right)$ thiophene is accessible if $\mathrm{CF}_{3} \mathrm{SO}_{3} \mathrm{H}$ is added as its Ag-salt [77]. Such reactions can also be successfully carried out on pyrroles (Scheme 21).
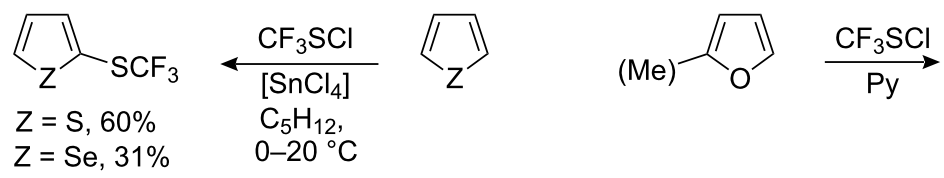

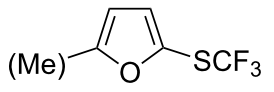

Scheme 17: Reactions of furan, thiophene and selenophene with $\mathrm{CF}_{3} \mathrm{SCl}$.

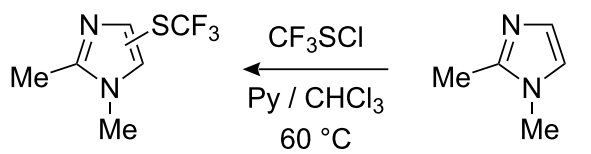<smiles>Cc1cnc(C)s1</smiles>

$\underset{\mathrm{Py} / \mathrm{CHCl}_{3}}{\stackrel{\mathrm{CF}_{3} \mathrm{SCl}}{\longrightarrow}}$

$60^{\circ} \mathrm{C}$

Scheme 18: Trifluoromethylsulfanylation of imidazole and thiazole derivatives [83]. 


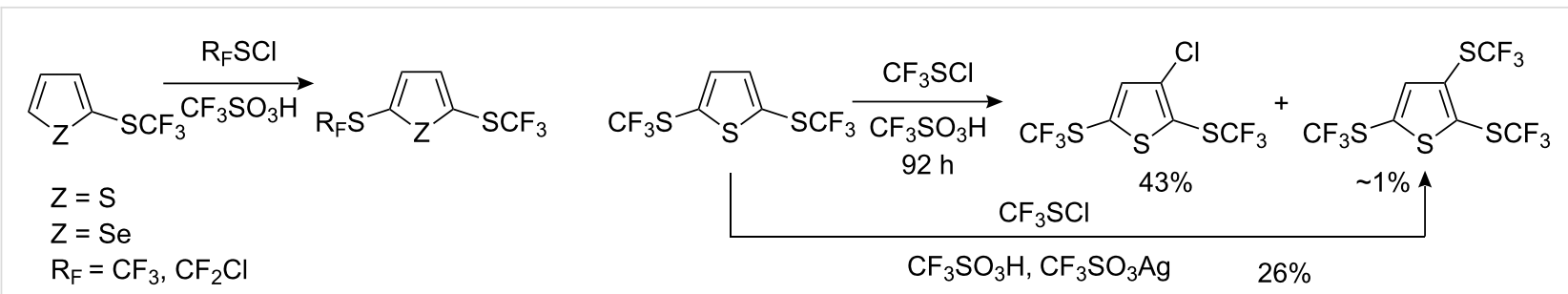

Scheme 20: Introduction of additional $\mathrm{R}_{\mathrm{F}} \mathrm{S}$-groups into heterocyclic compounds in the presence of $\mathrm{CF}_{3} \mathrm{SO}_{3} \mathrm{H}$.

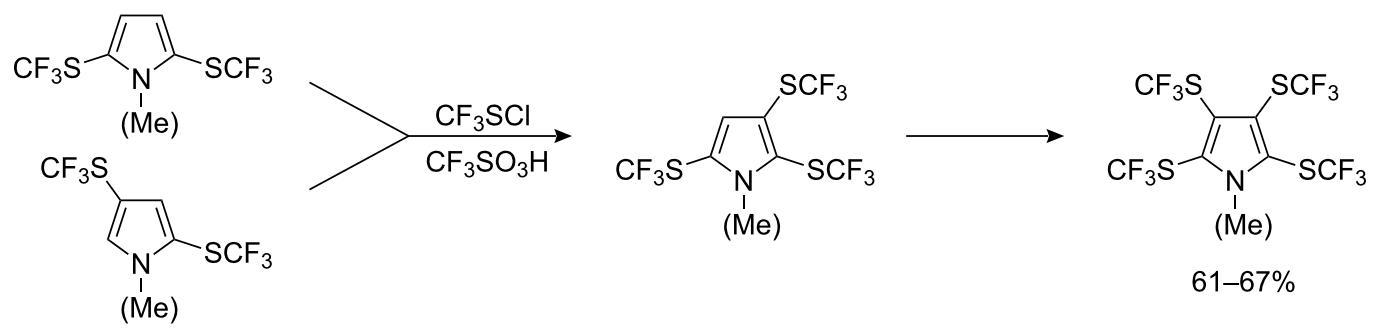

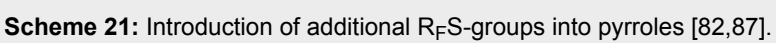

Prolonged reaction times lead to chlorinated products as well as products that arise from migration of the $\mathrm{CF}_{3} \mathrm{~S}$-groups (Scheme 22).

Thus, the reaction of perfluoroalkanesulfenyl chlorides with electron-rich aromatic and heterocyclic compounds offers an effective and comparatively straightforward method for the introduction of one or more $\mathrm{SR}_{\mathrm{F}}$ groups. The reactions are more problematic however, for electron deficient substrates where competing halogenation, reduction and isomerization products often result from perfluoroalkylthiolation reactions.

\subsection{Nucleophilic introduction of $\mathrm{SR}_{\mathrm{F}}$ groups}

Anionic salts of type $\mathrm{R}_{\mathrm{F}} \mathrm{S}^{-} \mathrm{M}^{+}$and their heavy metal complexes have been known for many years [88], however their application to the synthesis of aromatic perfluoroalkyl sulfides is comparatively recent. For example, trifluoromethylthiomercury and trifluoromethylthiosilver react with aliphatic halogenides to generate aliphatic and benzylic trifluoromethyl sulfides [89-92]
It is well known that the reaction of non-activated aryl halides with phenols, thiophenols and amines are catalyzed effectively by copper (Ullmann reaction). L. M. Yagupol'skii [93-97] developed a related protocol for trifluoromethylsulfanylation of aromatic and heterocyclic compounds using trifluoromethylthiocopper (Scheme 23).

$$
\begin{aligned}
& \text { 2-CHO-3,5-( }\left(\mathrm{SCF}_{3}\right)_{2} ; 2,3-\text { and } 3,4-(\mathrm{COOEt})_{2} \\
& \mathrm{DMF}, 150-165{ }^{\circ} \mathrm{C}
\end{aligned}
$$

Scheme 23: Reaction of aromatic iodides with $\mathrm{CuSCF}_{3}[93,95]$.

The reaction is carried out by heating in a polar solvent (e.g. DMF, quinoline or $N$-methyl pyrrolidone) and the substrate can

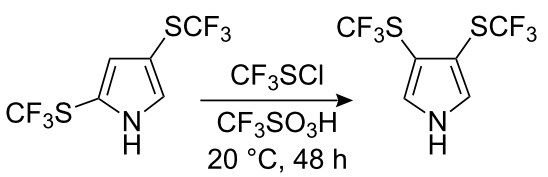
$20{ }^{\circ} \mathrm{C}, 48 \mathrm{~h}$<smiles>Cn1c(SC(F)(F)F)cc(SC(F)(F)F)c1SC(F)(F)F</smiles>

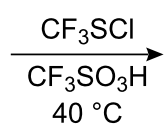<smiles>Cn1c(SC(F)(F)F)c(Cl)c(SC(F)(F)F)c1SC(F)(F)F</smiles>

$9 \%$<smiles>Cn1c(SC(F)(F)F)c(SC(F)(F)F)c(SC(F)(F)F)c1C(F)(F)F</smiles> 
contain electron-donating or electron-withdrawing groups. Electron-withdrawing groups activate the iodo atom and consequently, give better yields (70-75\%). 2-Trifluoromethylsulfanylpyridine, 6-trifluoromethylsulfanylquinoline [93] and 1-trifluoromethylsulfanylnaphthalene [97] are obtained in good yields $(60-70 \%)$ by this method. Multiple aromatic iodine substituents result in multiple substitution by $\mathrm{SCF}_{3}$ (Scheme 24).

In the cases of triiodo derivatives, the yields generally do not exceed $30 \%$. Thus, the synthesis of $1,3,5$-tris $\left(\mathrm{SCF}_{3}\right)$ benzene is more efficient via 3,5-bis $\left(\mathrm{SCF}_{3}\right)$-iodobenzene [93]. Hexaiodobenzene reacts with $\mathrm{CuSCF}_{3}$ to form hexakis(trifluoromethylsulfanyl)benzene in modest yield (41\%). However, with $\mathrm{CuSC}_{6} \mathrm{~F}_{5}$ and $\mathrm{CuSeCF}_{3}$ the corresponding hexa-substituted thio- and seleno-derivatives are obtained in yields of 70-90\% [96].

It should be noted that the interaction of $\mathrm{CuSCF}_{3}$ with aromatic iodides is sometimes accompanied by side-reactions. For example, the introduction of $\mathrm{CF}_{3} \mathrm{~S}$ groups into 2,6-diiodo-4nitrochlorobenzene and 2,6-diiodo-4-nitroanisole involve simultaneous reduction and substitution (Scheme 25).

Trifluoromethylthiocopper is obtained by reaction of $\mathrm{CuBr}$ with $\mathrm{AgSCF}_{3}[93,99]$, the latter is generated from silver fluoride and carbon disulfide $[90,100]$.

To simplify the process, Remy [101,102] suggested carrying out the synthesis of aryltrifluoromethyl sulfides by generation $\mathrm{CuSCF}_{3}$ (from trifluoromethylthio mercury and -copper) in situ with the aryl halides. This not only reduces the number of steps but also increases the overall efficiency (Scheme 26).

Aryl bromides can also be used but require higher temperatures $\left(150-190{ }^{\circ} \mathrm{C}\right)$ and more polar solvents. Under such forcing conditions compounds containing both electron-withdrawing and electron-donating groups can now be used effectively. In the case of $p$-bromo- $N, N$-dimethylaniline an excess ( 3 equiv) of the reagent was used. Aromatic chlorides do not react under<smiles>FC(F)(F)c1ccc(S(=S)(=S)c2ccc(I)cc2)cc1</smiles><smiles>O=[N+]([O-])c1cc(I)cc(I)c1</smiles>

$75 \%$<smiles></smiles>

3,6- and 4,5-isomers<smiles>[R]c1c(I)cc(I)cc1I</smiles>

$\mathrm{R}=\mathrm{H}, \mathrm{Cl}$<smiles>Ic1c(I)c(I)c(I)c(I)c1I</smiles>

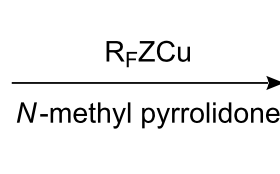<smiles>[R7]Cc1c([R7])c([R7])c([R7])c([R7])c1[R7]</smiles>

$\begin{array}{lr}\mathrm{ZR}_{\mathrm{F}} & \text { Yields } \\ \mathrm{SCF}_{3} & 41 \% \\ \mathrm{SC}_{6} \mathrm{~F}_{5} & 70 \% \\ \mathrm{SeCF}_{3} & 87 \%\end{array}$

Scheme 24: Reaction of aromatic iodides with $R_{F} Z C u(Z=S, S e), R_{F}=C F_{3}, C_{6} F_{5}[93,95,96]$.<smiles></smiles><smiles>COc1c(I)cc([N+](=O)[O-])cc1I</smiles><smiles>COc1c([N+](=O)[O-])cc([N+](=O)[O-])cc1S(F)(F)F</smiles><smiles>O=[N+]([O-])c1cc([As](F)(F)F)c(O)c(S(F)(F)(F)(F)F)c1</smiles> 


$$
\text { (7), }
$$

Scheme 26: Reactions with in situ generated $\mathrm{CuSCF}_{3}$.

these conditions. Thus, this method allows the selective substitution of different halogens by varying the temperature.

Since the original work on trifluoromethylthiocopper and trifluoromethylthiomercury $[93,95,96,101,102]$, other nucleophilic reagents and new methods have been developed. For example, Clark et al. have used $\mathrm{CuSCF}_{3}$ adsorbed onto $\mathrm{Al}_{2} \mathrm{O}_{3}$ [100], whilst Munavalli et al. have employed the acetonitrile adduct $\mathrm{CF}_{3} \mathrm{SCu} \cdot \mathrm{CH}_{3} \mathrm{CN}$ [103] for the reaction with $m$-iodobenzoic acid and its methyl ester [104].

Bulky perfluoroalkylthiocopper reagents, derived from 2,2,4,4tetrakis $\left(\mathrm{CF}_{3}\right)$-1,3-dithietane, hexafluoropropene and alcohols in the presence of $\mathrm{KF}$ or $\mathrm{CuBr}$, have been also used for reaction with substituted iodobenzenes (Scheme 27).
A variety of perfluoroalkyl- and perfluoroarylcopper mercaptides and selenides have become more accessible, prepared by cleavage of the corresponding disulfides and diselenides with copper powder [94]. The resultant $\mathrm{R}_{\mathrm{F}} \mathrm{ZCu}$ reagents complexed with DMF or $N$-methylpyrrolidone, are quite stable and can be stored without decomposition, can be used for the production of aryltrifluoromethyl-, arylpentafluorophenyl sulfides and -selenides from the corresponding iodobenzenes (Scheme 28) [94].

$$
\begin{aligned}
& \mathrm{R}_{\mathrm{F}} \mathrm{Z}-\mathrm{ZR}_{\mathrm{F}} \stackrel{\mathrm{Cu}}{\longrightarrow} \mathrm{R}_{\mathrm{F}} \mathrm{ZCu} \\
& \mathrm{R}_{\mathrm{F}}=\mathrm{CF}_{3}, \mathrm{C}_{6} \mathrm{~F}_{5} \\
& \mathrm{Z}=\mathrm{S}, \mathrm{Se} \\
& \mathrm{R}=4-\mathrm{NO}_{2}, 2,4-\left(\mathrm{NO}_{2}\right)_{2}
\end{aligned}
$$

Scheme 28: In situ formation and reaction of $\mathrm{R}_{\mathrm{F}} \mathrm{ZCu}$ with aryl iodides.

The compounds shown in Figure 6 have been synthesized by this method.

An alternative approach for the generation of $\mathrm{CF}_{3} \mathrm{SCu}$ involves heating of methyl fluorosulfonyl difluoroacetate in polar aprotic solvents to generate difluorocarbene, which in the presence of $\mathrm{CuI}$ and sulfur, forms trifluoromethylthiocopper [106]. Subsequent reaction with aryl halides results in the corresponding trifluoromethylsulfanyl derivatives (Scheme 29).

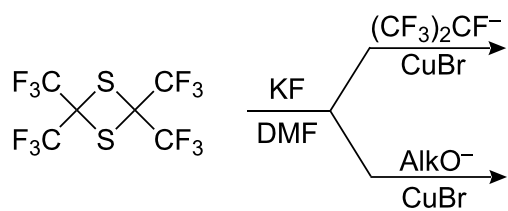<smiles>FC(F)(F)C(F)(F)C(F)(F)[Ge](F)(F)C(F)(F)F</smiles>

$\mathrm{R}=\mathrm{H}, o-, m-, p-\mathrm{CH}_{3}, o-, m-, p-\mathrm{NO}_{2}, p-\mathrm{F}, o-\mathrm{COOH}, o-\mathrm{COOMe}$

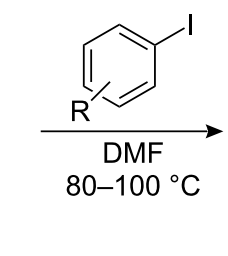

$80-100{ }^{\circ} \mathrm{C}$<smiles>OC(C(F)(F)F)(C(F)(F)F)C(F)(F)C(F)(F)F</smiles>

\section{-COOMe}<smiles>[R]c1ccc(SC([Y])([3H])C([3H])([3H])[3H])cc1</smiles>

$\mathrm{X}=\mathrm{CF}\left(\mathrm{CF}_{3}\right)_{2}, \mathrm{OCH}_{3}$

Scheme 27: Perfluoroalkylthiolation of aryl iodides with bulky $\mathrm{R}_{\mathrm{F}} \mathrm{SCu}$ [105]<smiles>FC(F)(F)c1ccccn1</smiles>

$75 \%$<smiles>FC(F)(F)[Se]c1cc([Se]C(F)(F)F)cc(C(F)(F)F)c1</smiles>

$74 \%$<smiles>CC(C)(C)O[AsH2]C(C)(C)C</smiles>

$Z_{\mathrm{F}} \quad$ Yields

$\mathrm{SCF}_{3} \quad 41 \%$

$\mathrm{SC}_{6} \mathrm{~F}_{5} \quad 70 \%$

$\mathrm{SeCF}_{3} \quad 87 \%$

$\mathrm{SeC}_{6} \mathrm{~F}_{5} 75 \%$ 


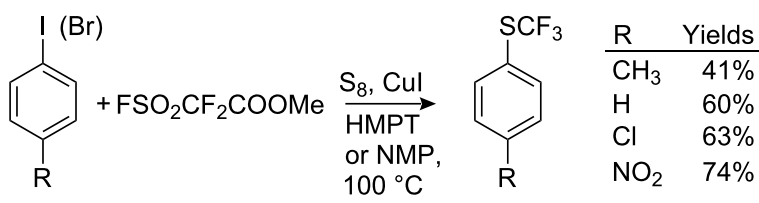

Scheme 29: Introduction of $\mathrm{SCF}_{3}$ group into aromatics via difluorocarbene.

Reduction of bis(perfluoroalkyl)disulfides with tetrakis(dimethylamino)ethylene produces tetrakis(dimethylamino)ethylene dication stabilized perfluoroalkyl thiolates. In contrast to the corresponding potassium and tetramethylammonium salts [29], this compound is stable and can be isolated in a pure state [107], and reacts with activated aryl halides to form the corresponding trifluoromethyl sulfides often in quantitative yields (Scheme 30).
Dmowski and Haas used the reaction of thiocarbonyl difluoride with metal fluorides, to generate the trifluoromethylthiolate anion [108] for introduction into activated perfluoroheterocyclic compounds. Thus, reaction of $\mathrm{CF}_{2} \mathrm{~S} / \mathrm{CsF}$ with pentafluoropyridine under mild conditions gave the 4-substituted product [109]. However, for the subsequent introduction of additional $\mathrm{SCF}_{3}$ groups this system is not suitable due to effective selfcondensation of thiocarbonyl difluoride $\left(\mathrm{CF}_{2}=\mathrm{S}\right)$ at higher concentrations. For this purpose the trimer of thiocarbonyl difluoride, bis(trifluoromethyl)trithiocarbonate $\left(\mathrm{CF}_{3} \mathrm{~S}\right)_{2} \mathrm{C}=\mathrm{S}$, is more stable and reacts with $\mathrm{CsF}$ in sulfolane to generate $\mathrm{CF}_{3} \mathrm{~S}^{-}$ anions [110]. However, the use of this reagent leads to mixtures of products (Scheme 31).

Whilst reaction of $\mathrm{CF}_{2}=\mathrm{S} / \mathrm{CsF}$ (or its trimer) with tetrafluoropyridazine allows for the selective formation of mono-, di- and tri$\left(\mathrm{SCF}_{3}\right)$ substituted products, the analogous reaction with tetra-

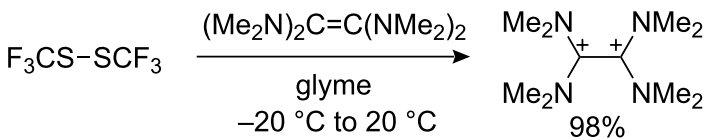

$$
\begin{aligned}
& \mathrm{ArX}=\mathrm{N} \mathrm{F}-\mathrm{F}(80 \%), 2,4-\left(\mathrm{NO}_{2}\right)_{2} \mathrm{C}_{6} \mathrm{H}_{3} \mathrm{Cl}(95 \%)
\end{aligned}
$$
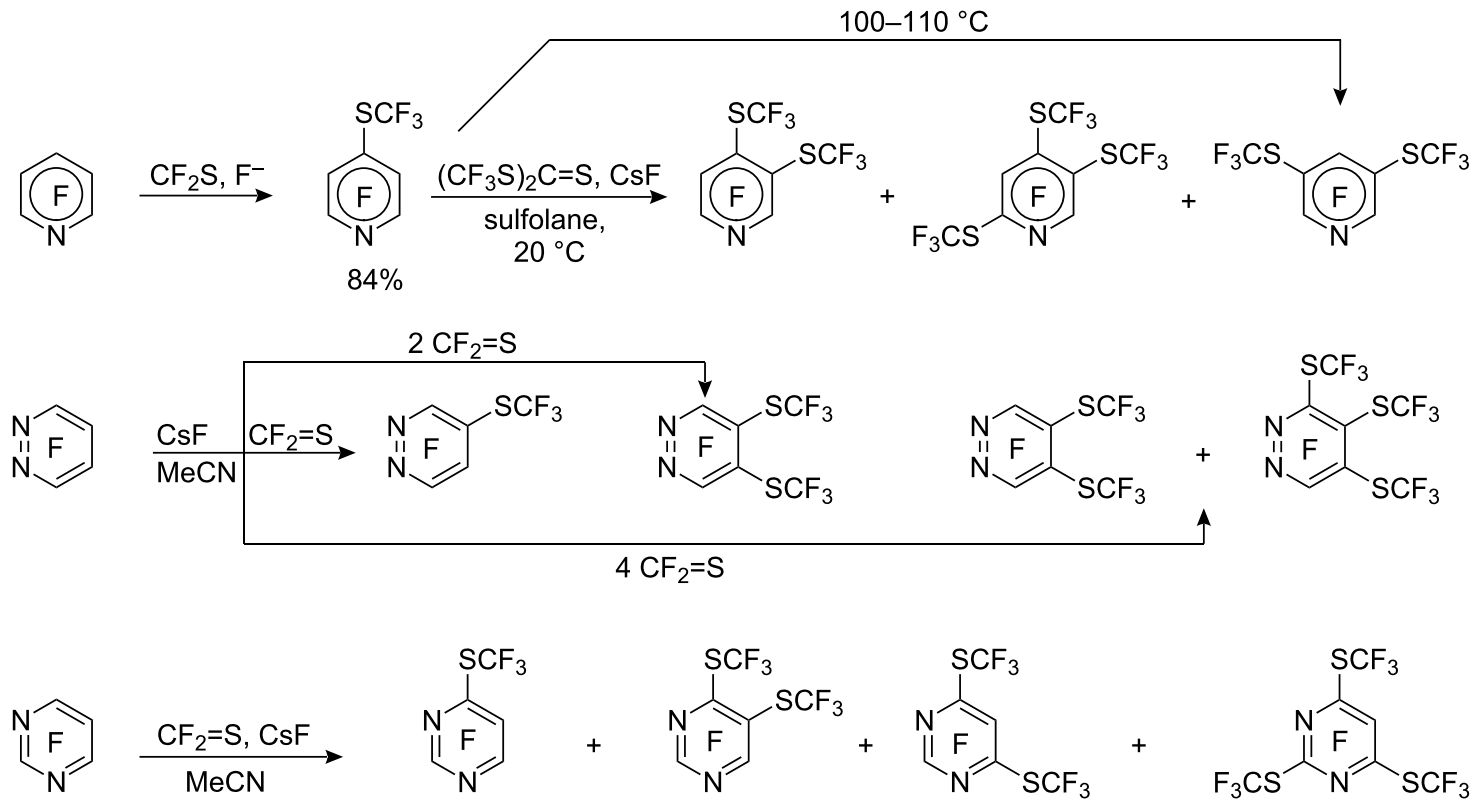


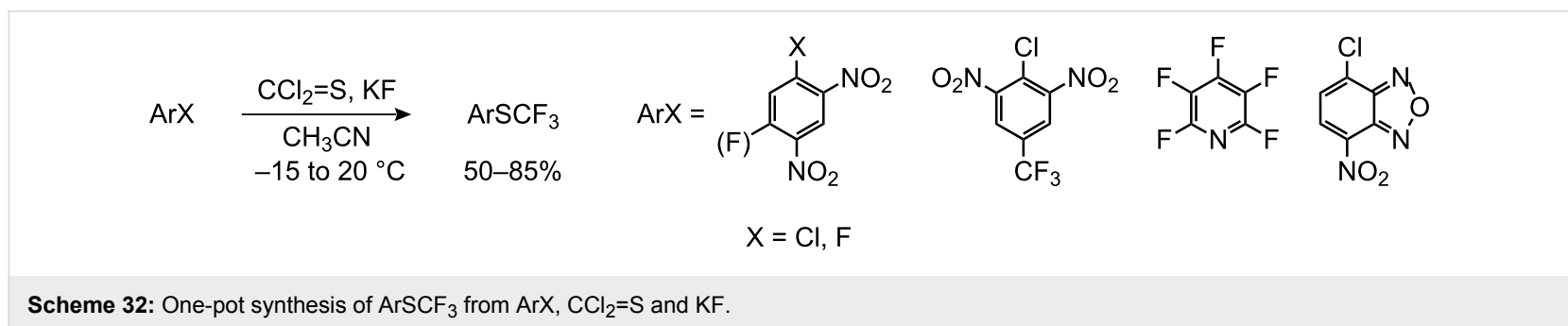

fluoropyrimidine results in a mixture of polyfluoropyrimidine derivatives [111] (Scheme 31). Interestingly, the reaction of $\left(\mathrm{CF}_{3} \mathrm{~S}\right)_{2} \mathrm{C}=\mathrm{S} / \mathrm{CsF}$ with $\mathrm{C}, \mathrm{N}$-bis(pentafluorophenyl) imidoyl chloride leads to introduction of the $\mathrm{SCF}_{3}$ group into the pentafluorophenyl ring along with substitution of the imidoylic chlorine atom [112].

A considerable improvement of this method was developed by Clark et al. [113]: No preliminary preparation of difluorothiophosgene or its trimer is necessary, the required reagents being generated in situ (from thiophosgene and KF). The reaction with activated aromatic compounds is shown in Scheme 32.

The less reactive 2-Cl-5- $\mathrm{NO}_{2}$ benzonitrile forms the $\mathrm{CF}_{3} \mathrm{~S}$ derivative in only $49 \%$ yield after many hours reflux and 2-F-5$\mathrm{NO}_{2}$ benzonitrile is a by-product despite the use of a $100 \%$ excess of thiophosgene.

The use of $\mathrm{Me}_{4} \mathrm{NF}$ in place of $\mathrm{KF}$ for the generation of the $\mathrm{CF}_{3} \mathrm{~S}^{-}$anion in reactions with 2,4-dinitrofluorobenzene and pentafluoropyridine increases the yields of the corresponding trifluoromethyl sulfides to $90-96 \%[29,114]$. However, with other substrates this method can be problematic due to competing side reactions.

A new method for the preparation of trifluoromethylthiolate anion involves the reaction of $\mathrm{Me}_{3} \mathrm{SiCF}_{3}$ with sulfur in the presence of a fluoride ion source [115]. The salts obtained by this method are considerably more thermally stable than those previously reported $[29,110,114]$. They can be treated with boiling ether or $\mathrm{CS}_{2}$ to remove excess sulfur and readily react at room temperature with inorganic, aliphatic and activated aromatic halides with the formation of trifluoromethyl sulfides (Scheme 33).

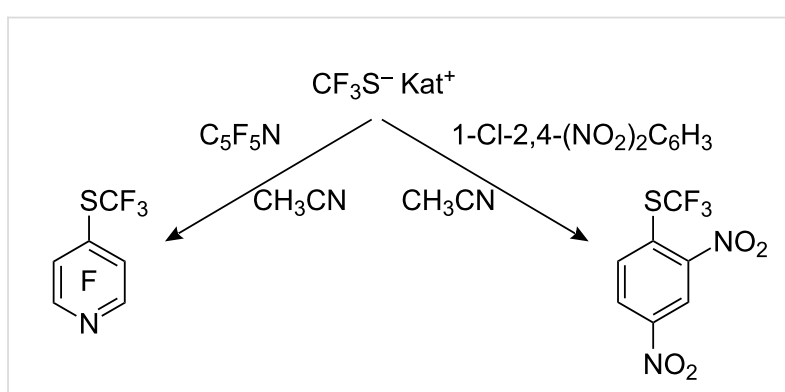

Scheme 33: Reaction of aromatics with $\mathrm{CF}_{3} \mathrm{~S}^{-} \mathrm{Kat}^{+}$[115].

It has already been noted that trifluoromethylthiomercury and trifluoromethylthiosilver cannot be used for the preparation of aryltrifluoromethyl sulfides, as they react only with aliphatic halides [89-92]. However, it is known [116,117], that $\mathrm{Hg}\left(\mathrm{SCF}_{3}\right)_{2}$ forms a complex with $\mathrm{KI}$ which decomposes with the formation of an unstable anion "- $\mathrm{SCF}_{3}$ ". Based on this observation, Adams and Clark used a mixture of trifluoromethylthiosilver and $\mathrm{KI}$ (or $\mathrm{Bu}_{4} \mathrm{NI}$ ) as a source of trifluoromethylthiolate anion for nucleophilic introduction of the trifluoromethylsulfanyl moiety into aromatic molecules [118]. Of the metal halides investigated for this reaction, the best results were obtained with $\mathrm{KI}$ and $\mathrm{Bu}_{4} \mathrm{NI}$, whilst $\mathrm{NaI}, \mathrm{NaBr}$, and $\mathrm{KF}$ were ineffective. Some of these reactions are illustrated in Scheme 34.

This reagent can displace a range of activated halides, particularly bromides and iodides. For the reaction of 2,4-<smiles></smiles><smiles>[R]c1ccc(Cl)c([R])c1</smiles>

\begin{tabular}{llr}
$\mathrm{R}$ & $\mathrm{R}^{\prime}$ & Yield \\
\hline $\mathrm{NO}_{2}$ & $\mathrm{NO}_{2}$ & $64 \%$ \\
$\mathrm{NO}_{2}$ & $\mathrm{CN}$ & $25 \%$ \\
$\mathrm{CN}$ & $\mathrm{NO}_{2}$ & $16 \%$
\end{tabular}

$100 \%$ 


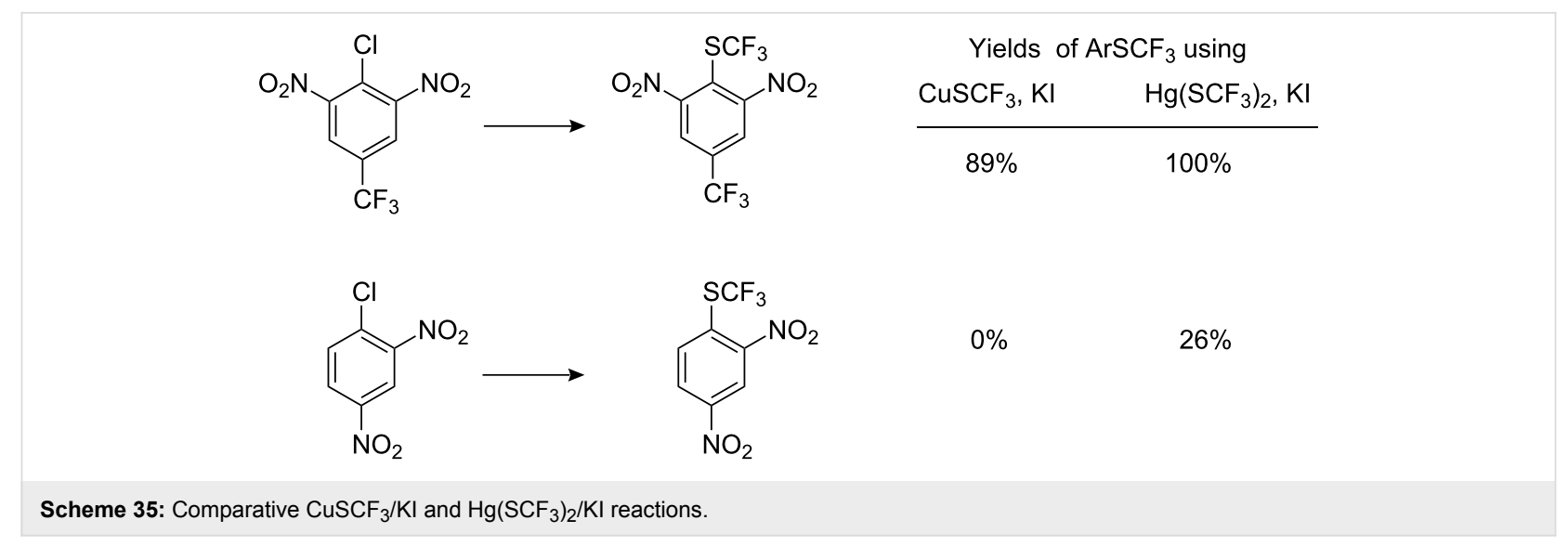

$\left(\mathrm{NO}_{2}\right)_{2} \mathrm{C}_{6} \mathrm{H}_{3} \mathrm{X}$ with $\mathrm{AgSCF}_{3} / \mathrm{KI}$, the reactivity of the halogens occurs in the reverse sequence: $\mathrm{F}(26 \%)<\mathrm{Cl}(52 \%)<\mathrm{Br}(85 \%)$ $<$ I (97\%) [118]. Presumably, coordination of the complex anionic nucleophile $\mathrm{K}^{+}\left[\mathrm{Ag}\left(\mathrm{SCF}_{3}\right) \mathrm{I}^{-}\right.$with aryl halide accelerates the reaction.

Trifluoromethylthiocopper and trifluoromethylthiomercury also participate in analogous reactions, $\mathrm{CuSCF}_{3}$ is less active than $\mathrm{AgSCF}_{3}$ whilst $\mathrm{Hg}\left(\mathrm{SCF}_{3}\right)_{2}$ displays increased reactivity as indicated in Scheme 35 [118].

It should be noted that the tellurium reagent, $\mathrm{Me}_{3} \mathrm{SnTeCF}_{3}$, is capable of introducing the $\mathrm{TeCF}_{3}$ group into activated heteroaromatics [119]. In the reaction shown (Scheme 36) the use of three equivalents resulted in the introduction of only two $\mathrm{TeCF}_{3}$ groups.

The Sandmeyer reaction is used widely to introduce functionality into aromatic compounds. However, early attempts using trifluoromethylthiosilver as the nucleophile were not encouraging [120] with yields below $30 \%$ accompanied with deaminated side products (up to $38 \%$ ). The use of trifluoromethylthiocopper was rather unsuccessful. However, with diazonium salts generated with tert-butyl nitrite in acetonitrile in the presence of $\mathrm{CuSCF}_{3}$ and $\mathrm{BF}_{3}$ better results were obtained [121]. Yields of the resulting aryltrifluoromethyl sulfides improved ( $40-70 \%)$. The best results were observed with isolated tetrafluoroborate

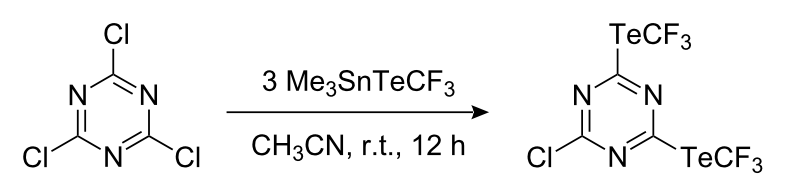

Scheme 36: $\mathrm{Me}_{3} \mathrm{SnTeCF}_{3}$ - a reagent for the introduction of the $\mathrm{TeCF}_{3}$ group.

diazonium salts (Scheme 37), although the presence of electrondonating and bulky ortho-substituents in the aromatic ring led to reduced yields.

\section{Perfluoroalkylation of aromatic sulfur com- pounds}

Perfluoroalkyl iodides have not generally been considered as alkylating agents. Unlike R-X they show anomalous behavior in their reactions with nucleophiles. For example, the reaction of $\mathrm{CF}_{3} \mathrm{I}$ with alkali gives fluoroform $\left(\mathrm{CHF}_{3}\right)$ and potassium hypoiodide (KIO) [122]. The interaction of organolithium compounds with perfluoroalkyl iodides [123-126] does not result in combination of the two alkyl species $\left(\mathrm{R}_{\mathrm{F}}\right.$ and $\left.\mathrm{R}\right)$, but in transmetallation (Scheme 38).

Such reactivity has been explained by the reverse polarization of the $\mathrm{C}-\mathrm{I}$ bond in the fluorinated substrates. Because of the greater electronegativity of $\mathrm{CF}_{3}$ over iodine (3.3 for $\mathrm{CF}_{3}$ and

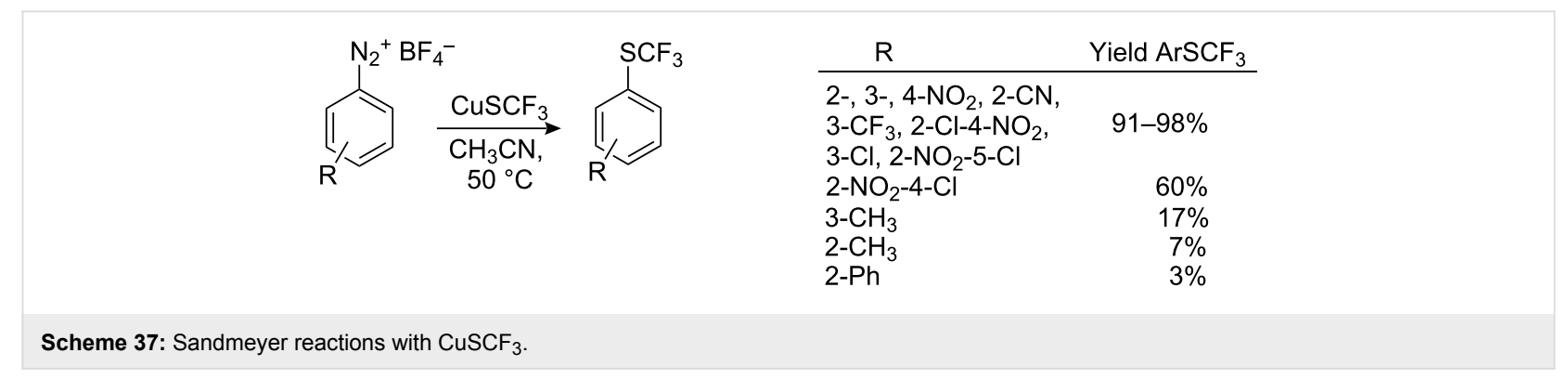




$$
\begin{aligned}
& \mathrm{CF}_{3} \mathrm{I}+\mathrm{KOH} \longrightarrow \mathrm{CHF}_{3}+\mathrm{KOI} \\
& \mathrm{R}_{\mathrm{F}}+\mathrm{RLi} \longrightarrow \mathrm{R}_{\mathrm{F}} \mathrm{Li}+\mathrm{RI} \\
& \mathrm{R}_{\mathrm{F}}=\mathrm{C}_{n} \mathrm{~F}_{2 n+1}(n=1-8), \mathrm{CF}\left(\mathrm{CF}_{3}\right)_{2} \\
& \mathrm{R}=\mathrm{Me}, \mathrm{Bu}, \mathrm{Ph}
\end{aligned}
$$

Scheme 38: Reactions of perfluoroalkyl iodides with alkali and organolithium reagents.

2.5 for the atom of iodine $[127,128])$, the iodine acquires a partial positive charge:

$$
\begin{array}{cc}
\delta-\delta^{+} & \delta+\delta- \\
\mathrm{F}_{3} \mathrm{C}-\mathrm{I} & \mathrm{H}_{3} \mathrm{C}-\mathrm{I}
\end{array}
$$

Nevertheless, Haszeldine et al., were able to carry out the perfluoroalkylations of alkylthiols. Prolonged heating of polyfluoroalkyl iodides with the sodium methylthiolate at $100-110{ }^{\circ} \mathrm{C}$ in DMSO lead to the formation of methyl polyfluoroalkyl sulfides [129]. The halophilic generated carbanion $\left(\mathrm{R}_{\mathrm{F}}{ }^{-}\right)$in turn reacted with the sulfenyl iodide to generate a thioether. However, $\mathrm{R}_{\mathrm{F}} \mathrm{CH}_{3}$ and $\mathrm{R}_{\mathrm{F}} \mathrm{H}$, are also obtained as by-products, which may be a result of homolytic decomposition of the perfluoroalkyl iodides at high temperature $[130,131]$ Similarly, reactions of $\mathrm{R}_{\mathrm{F}} \mathrm{I}$ with sodium thiophenoxide (like other aromatics such as halogenated benzenes [132] or aromatic heterocycles [133]) resulted in the introduction of the perfluoroalkyl radical into aromatic rings with the formation of a mixture of isomeric $\mathrm{R}_{\mathrm{F}}$-compounds.

\subsection{Ion-radical perfluoroalkylation}

4.1.1. Interaction of S-, Se- and Te-phenols, and diaryl disulfides with perfluoroalkyl iodides in liquid ammonia under UV irradiation

Kornblum's work on nucleophilic substitution in alkyl halides [134-137] and Bunnett's reactions with non-activated aromatic substrates [138-142] (under UV irradiation) introduced the concept of the nucleophilic radical substitution mechanism $\left(\mathrm{S}_{\mathrm{RN}} 1\right)$. The essence of this approach consists of the generation of the anionic radical $\mathrm{RHlg}^{-\bullet}$, its decomposition to a radical $\mathrm{R}^{\bullet}$ (Alk ${ }^{\bullet}$ or $\mathrm{Ar}^{*}$ ) followed by reaction with a nucleophile.

Although perfluoroalkyl iodides have a reversed polarity, and in spite of their tendency to undergo homolytic decomposition under UV irradiation, it is probable that they are also able to react with thiolate anions by a similar mechanism. Indeed, they react readily with aliphatic, aromatic and heterocyclic thiols [143-146], and with seleno- [147] and tellurophenols [148] under UV irradiation with formation of corresponding perfluoroalkyl sulfides, -selenides and -tellurides. The original method required liquid ammonia as the solvent and Pyrex glassware. Thiophenol and its derivatives containing both, electrondonating and electron-withdrawing substituents are easily transformed to the corresponding arylperfluoroalkyl sulfides in high yields (Table 1).

$\alpha, \omega$-Diiodoperfluoroalkanes react at both reaction centers with the formation of bis(SAr)-derivatives containing perfluoroalkylene bridges $[144,146]$ in yields of $80-96 \%$.

With the exception of 4-nitrothiophenol, the reactions are independent of the type of substituents. Unlike many thiophenoxides which bear electron-withdrawing substituents $(p-\mathrm{Cl}, 2,4-$ $\mathrm{Cl}_{2}, o-\mathrm{SO}_{2} \mathrm{CHF}_{2}$ and even $p-\mathrm{SO}_{2} \mathrm{CF}_{3}$ ), sodium 4-nitrothiophenoxide affords $4,4^{\prime}$-dinitrodiphenyl disulfide under these conditions. Conversion to 4-nitrophenyl trifluoromethyl sulfide (60\% yield) requires prolonged irradiation in a quartz ampoule at $30-45^{\circ} \mathrm{C}$ [143]. The length of the perfluoroalkyl iodide chain has no influence, although lower yields were observed using $\mathrm{CF}_{3} \mathrm{I}$ in comparison with other iodoperfluoroalkanes. A branching $\mathrm{R}_{\mathrm{F}} \mathrm{I}$ chain results in lower yields of the corresponding sulfides (10-15\%). In the case of tertiary perfluorobutyl iodide, thiophenols are quantitatively transformed into diaryl disulfides. Such behavior of branched perfluoroalkyl iodides can be explained by the facile generation of the $\mathrm{I}^{\bullet}$ radical both as a consequence of their homolytic decomposition [155] and the decomposition of in situ generated radical anions [156]: $i-\mathrm{R}_{\mathrm{F}} \mathrm{I}^{-\bullet} \rightarrow i-\mathrm{R}_{\mathrm{F}}^{-}+\mathrm{I}^{\bullet}$. The radical $\mathrm{I}^{\bullet}$ (or $\mathrm{I}_{2}$ ) oxidizes the $\mathrm{ArS}^{-}$anion to disulfide.

Diaryl disulfides may also be used as substrates. Although they can be trifluoromethylated directly [157], unlike dialkyl disulfides $[130,131]$ the yields generally do not exceed $40 \%$ (except for nitro derivatives $4-\mathrm{NO}_{2}-58 \%, 2-\mathrm{NO}_{2}-72 \%$ ). The preliminary breaking of the $\mathrm{S}-\mathrm{S}$ bond can be carried out very mildly and selectively [9], without affecting other functional groups (Scheme 39).

Perfluoroalkylthioanilines are accessible in a one-pot perfluoroalkylation reaction of dinitrodiphenyl disulfides [158,159] (Scheme 40). This method gives good yields of the desired products, higher than those from the perfluoroalkylation of amino thiophenols.

Seleno- [147] and telluro phenols [148] also react with perfluoroalkyl iodides under UV irradiation. Subsequently, it was shown that $\mathrm{ArSeNa}$ and ArTeNa react with perfluoroalkyl halides without irradiation to generate $\mathrm{R}_{\mathrm{F}}{ }^{\bullet}$ radicals which react with olefins $[160,161]$. Irradiation of polymercapto derivatives of benzene and $\mathrm{CF}_{3} \mathrm{I}$ in liquid ammonia gives poly(trifluoromethylsulfanyl) compounds in high yields (Table 2). 
Table 1: Interaction of thiophenols with perfluoroalkyl iodides in liquid ammonia under UV irradiation.

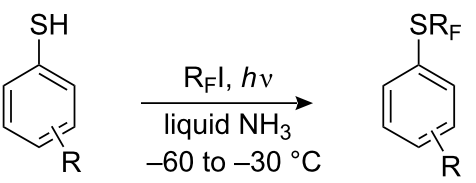

$70-90 \%$

\begin{tabular}{|c|c|c|c|}
\hline $\mathrm{R}$ & $\mathrm{R}_{\mathrm{F}}$ & Yields of $\mathrm{ArSR}_{\mathrm{F}}, \%$ & Ref. \\
\hline \multirow[t]{2}{*}{$\mathrm{H}$} & $\mathrm{CF}_{3}$ & 76 & [143] \\
\hline & $\mathrm{C}_{2} \mathrm{~F}_{5}, n-\mathrm{C}_{3} \mathrm{~F}_{7}$, iso- $\mathrm{C}_{3} \mathrm{~F}_{7}$ & $84,81,76$ & [144] \\
\hline $4-\mathrm{NH}_{2}$ & $\mathrm{CF}_{3}$ & 87 & {$[146]$} \\
\hline 2- $\mathrm{NH}_{2}$ & $\mathrm{CF}_{3}$ & 71 & [143] \\
\hline $4-\mathrm{OH}$ & $\mathrm{CF}_{3}$ & 69.5 & [143] \\
\hline $2-\mathrm{OCH}_{3}$ & $\mathrm{CF}_{3}$ & 86 & [98] \\
\hline \multirow[t]{2}{*}{$4-\mathrm{Cl}$} & $\mathrm{CF}_{3}$ & 72 & {$[146]$} \\
\hline & $\mathrm{C}_{2} \mathrm{~F}_{5}, n-\mathrm{C}_{3} \mathrm{~F}_{7}$, iso- $\mathrm{C}_{3} \mathrm{~F}_{7}$ & $84,83,65$ & {$[144]$} \\
\hline $2-\mathrm{SO}_{2} \mathrm{CHF}_{2}$ & $\mathrm{CF}_{3}$ & 69 & {$[143,146]$} \\
\hline $4-\mathrm{SO}_{2} \mathrm{CF}_{3}$ & $\mathrm{CF}_{3}$ & 78 & {$[143,146]$} \\
\hline \multirow[t]{2}{*}{$4-\mathrm{NO}_{2}$} & $\mathrm{CF}_{3}$ & $2.7^{\mathrm{a}}$ & {$[143,146]$} \\
\hline & & $63^{b}$ & {$[143,146]$} \\
\hline \multirow[t]{2}{*}{$2,4-\mathrm{Cl}_{2}$} & $\mathrm{CF}_{3}$ & 87 & {$[149]$} \\
\hline & $\mathrm{C}_{3} \mathrm{~F}_{7}$ & 89 & [149] \\
\hline $2-\mathrm{COOH}$ & $\mathrm{CF}_{3}$ & 90 & [150] \\
\hline 3- and 4- $\mathrm{COOCH}_{3}$ & $\mathrm{CF}_{3}, n-\mathrm{C}_{3} \mathrm{~F}_{7}$, iso- $\mathrm{C}_{3} \mathrm{~F}_{7}$ & $70-80$ & [151] \\
\hline \multirow[t]{2}{*}{ 3- and 4-F } & $\mathrm{CF}_{3}, n-\mathrm{C}_{3} \mathrm{~F}_{7}$ & $80-90$ & [152] \\
\hline & iso- $\mathrm{C}_{3} \mathrm{~F}_{7}$ & $72-75$ & [152] \\
\hline $4-\mathrm{NHCOCH}_{3}$ & $\mathrm{CF}_{3}$ & 96 & [153] \\
\hline \multirow{2}{*}{$4-\mathrm{NHCOOCH}_{3}$} & $\mathrm{CF}_{3}, n-\mathrm{C}_{3} \mathrm{~F}_{7}$ & $88\left(92^{\mathrm{C}}\right), 82\left(93^{\mathrm{C}}\right)$ & [9] \\
\hline & $\mathrm{C}_{2} \mathrm{~F}_{5}, \mathrm{C}_{4} \mathrm{~F}_{9}$ & 62,55 & [154] \\
\hline
\end{tabular}

an a quartz flask.

bIn a quartz ampoule at $30-45^{\circ} \mathrm{C}$.

'With preliminary reduction of 4,4'-bis(MeOCONH)diaryl disulfide and without the isolation of corresponding thiophenol.

However, the reaction of 2,4,6-trimercaptochlorobenzene with $\mathrm{CF}_{3}$ I generates a mixture of compounds A, B, C and D as illustrated in Scheme 41. Reducing the irradiation time from 30 to 5 min does not change the product composition.

Control experiments indicate that aniline (B) is not derived from either chloro- (A) and iodo- (C)-sulfides, and iodo-product $(\mathrm{C})$ is not formed from chlorosulfide (A). It is known [164] that photochemical nucleophilic aromatic substitution is promoted by electron-donating groups. Therefore, it appears most likely that the sulfides (B), (C) and (D) are produced as a consequence of loss of chloride from the intermediate radical anion as shown in Scheme 42.

Such side reactions explain the decrease of trifluoromethylation efficiency with the number of thiol groups present in a series of thiolated chlorobenzenes. The yields are $72 \%$ for $4-\mathrm{SH}-[146]$, $64 \%$ for $2,4-(\mathrm{SH})_{2}-[143]$ and $37 \%$ for $2,4,6-(\mathrm{SH})_{3}-[163]$.<smiles>CCOC(=O)Nc1ccc(SSc2ccc(NC(=O)OC(C)=O)cc2)cc1</smiles> 
<smiles>O=[N+]([O-])c1ccc(SSc2cccc([N+](=O)[O-])c2)cc1</smiles>

\begin{tabular}{ccc} 
Position of $\mathrm{NH}_{2}$ & $\mathrm{R}_{\mathrm{F}}$ & Yield \\
\hline$o-$ & $\mathrm{CF}_{3}$ & $85 \%$ \\
$m-$ & $\mathrm{CF}_{3}$ & $85 \%$ \\
$p-$ & $\mathrm{CF}_{3}$ & $75 \%$ \\
$p-$ & $\mathrm{C}_{3} \mathrm{~F}_{7}$ & $75 \%$
\end{tabular}

Scheme 40: Preparation of $\mathrm{R}_{\mathrm{F}} \mathrm{S}$-substituted anilines from dinitrodiphenyl disulfides.

Table 2: UV irradiation of polymercapto benzenes with $\mathrm{CF}_{3}$ I in liquid $\mathrm{NH}_{3}$.<smiles>[R]c1cccc([C+])c1</smiles>

$(\mathrm{SH})_{n}$<smiles>[R]c1ccccc1</smiles>

$\left(\mathrm{SCF}_{3}\right)_{n}$

\begin{tabular}{llll}
\hline $\mathrm{R}$ & Position of $(\mathrm{SH})_{n}$ and $\left(\mathrm{SCF}_{3}\right)_{n}$ & Yield & Ref. \\
\hline $\mathrm{Cl}$ & $2,4-$ & $64 \%$ & {$[143]$} \\
$\mathrm{COOH}$ & $3,5-$ & $89 \%$ & {$[162]$} \\
$\mathrm{CH}_{3}$ & $2,4,6-$ & $90 \%$ & {$[163]$} \\
$\mathrm{NH}_{2}$ & $2,4,6-$ & $88 \%$ & {$[163]$} \\
$\mathrm{OH}$ & $2,4,6-$ & $69 \%$ & {$[163]$}
\end{tabular}

\subsubsection{Perfluoroalkylation of heterocyclic thiols}

Heterocyclic thiol form $S$-perfluoroalkyl derivatives when irradiated in liquid ammonia in the presence of iodoperfluoroalkanes. The type of heterocyclic ring and the position of the thiol group influences the reaction. More electron-deficient heterocycles require longer irradiation times (Table 3 ).

It appears that 4-hydroxypyrimidine-2-thiol does not react with $\mathrm{CF}_{3} \mathrm{I}$ under standard conditions. Similar to the reaction of 4-nitrothiophenol noted above [143,146], this reaction requires more forcing conditions. Other 4-hydroxypyrimidine-2-thiols behave similarly. The irradiation of an ammoniacal solution of 2-mercapto-4-oxy-6-trifluoromethylyrimidine with $\mathrm{CF}_{3} \mathrm{I}$ must be conducted in a Pyrex ampoule at $30-45{ }^{\circ} \mathrm{C}$ to produce the $S$-trifluoromethyl derivative (Scheme 43).

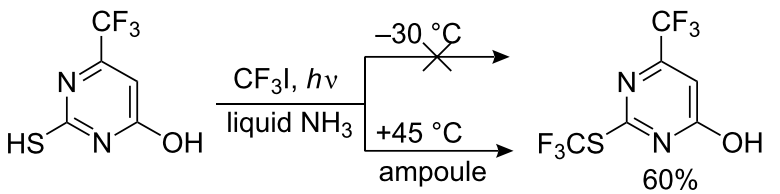

Scheme 43: Trifluoromethylation of 2-mercapto-4-hydroxy-6-trifluoromethylyrimidine [145].

Apparently, the reaction of these hydroxymercapto heterocyclic derivatives is complicated by stabilization of sulfur centred radicals as illustrated in Scheme 44.

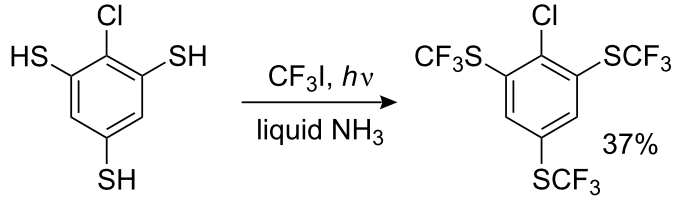

A<smiles>Nc1c(C(F)(F)F)cc(S(F)(F)(F)(F)F)cc1[Si](F)(F)C(F)(F)F</smiles><smiles>FC(F)(F)c1cc(S(F)(F)(F)(F)F)c(I)c([As](F)(F)(F)(F)F)c1</smiles>

C<smiles>FC(F)(F)c1cc(C(F)(F)F)cc([As](F)(F)F)c1</smiles>

D

Scheme 41: Photochemical trifluoromethylation of 2,4,6-trimercaptochlorobenzene [163]

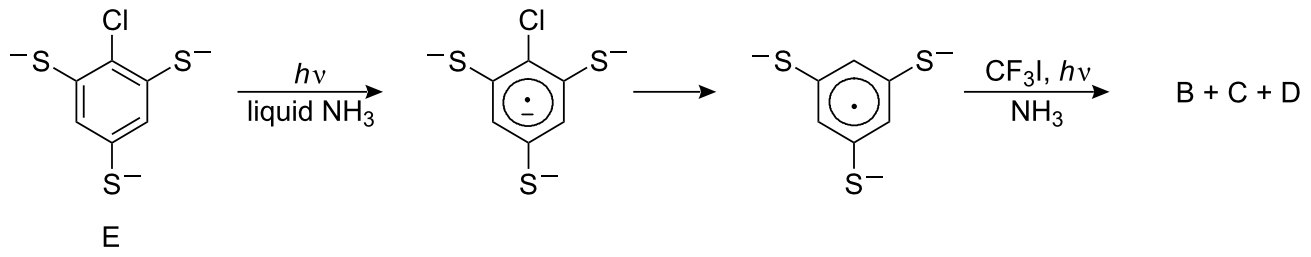

Scheme 42: Putative process for the formation of $B, C$ and D. 


\begin{tabular}{|c|c|c|c|c|}
\hline $\mathrm{R}$ & $\mathrm{R}_{\mathrm{F}}$ & Reaction conditions & Yield of products, $\%$ & Ref. \\
\hline \multicolumn{5}{|c|}{ 2-(SCF$\left.)_{3}\right)$-Benzothiazole } \\
\hline $\mathrm{H}$ & $\mathrm{CF}_{3}$ & -60 to $-33^{\circ} \mathrm{C}, 90 \mathrm{~min}$ & 87.5 & [143] \\
\hline \multicolumn{5}{|c|}{ 2-(SR $\left.{ }_{\mathrm{F}}\right)$-Benzimidazoles } \\
\hline \multirow[t]{2}{*}{$\mathrm{H}$} & $\mathrm{CF}_{3}$ & -50 to $-33^{\circ} \mathrm{C}, 4 \mathrm{~h}$ & 51 & [165] \\
\hline & $\mathrm{C}_{1}-\mathrm{C}_{4}$ & Pyrex ampoule, $30^{\circ} \mathrm{C}, 5 \mathrm{~h}$ & $63-80$ & [154] \\
\hline $5-\mathrm{Cl}$ & $\mathrm{C}_{2} \mathrm{~F}_{5}$ & liquid $\mathrm{NH}_{3}, \mathrm{THF}, 10 \mathrm{~h}$ & 56 & [166] \\
\hline \multicolumn{5}{|c|}{ 5-(SR $\mathrm{S}_{\mathrm{F}}$-Benzimidazoles ${ }^{\mathrm{a}}$} \\
\hline \multirow[t]{2}{*}{ 2-Bu } & $\mathrm{CF}_{3}$ & liquid $\mathrm{NH}_{3}$, ampoule, $25-40{ }^{\circ} \mathrm{C}, 10 \mathrm{~h}$ & 20-39 & [154] \\
\hline & $\mathrm{C}_{3} \mathrm{~F}_{7}$ & & & \\
\hline \multicolumn{5}{|c|}{ 5-(SR $\left.{ }_{\mathrm{F}}\right)-6$-Azauracil } \\
\hline \multirow[t]{2}{*}{$\mathrm{H}$} & $\mathrm{CF}_{3}$ & $-33^{\circ} \mathrm{C}, 45 \mathrm{~min}$ & 77 & {$[10]$} \\
\hline & $\mathrm{C}_{3} \mathrm{~F}_{7}$ & & 76 & \\
\hline \multicolumn{5}{|c|}{ 2-( $\left(\mathrm{SCF}_{3}\right)$-Pyrimidines } \\
\hline $4,6-\left(\mathrm{CH}_{3}\right)_{2}$ & $\mathrm{CF}_{3}$ & $-33^{\circ} \mathrm{C}, 60 \mathrm{~min}$ & 82 & [154] \\
\hline $4-\mathrm{SH}$ & $\mathrm{CF}_{3}$ & & $61^{b}$ & [154] \\
\hline 4-SH-6-CH 3 & $\mathrm{CF}_{3}$ & & $58^{b}$ & [154] \\
\hline $4-\mathrm{OH}-6-\mathrm{CF}_{3}$ & $\mathrm{CF}_{3}$ & Pyrex ampoule, $30-45^{\circ} \mathrm{C}, 5 \mathrm{~h}$ & 59 & [154] \\
\hline $4,6-\mathrm{Me}_{2}-5-\mathrm{OH}$ & $\mathrm{CF}_{3}$ & $-30^{\circ} \mathrm{C}, 4 \mathrm{~h}$ & 89 & [154] \\
\hline
\end{tabular}

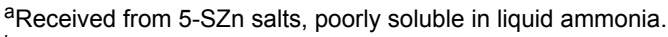

bThe 2,4-bis $\left(\mathrm{SCF}_{3}\right)$-derivatives.<smiles>O=c1ccnc(Sc2ccccc2)[nH]1</smiles>

Scheme 44: Deactivation of 2-mercapto-4-hydroxypyrimidines S-centered radicals.

In the case of 2-mercapto-5-hydroxypyrimidines, no tautomeric keto form such as that shown in Scheme 44 is possible and consequently, are perfluoroalkylated without any problems, e.g., 2-mercapto-5-hydroxy-4,6-dimethyl pyrimidine [145].

In summary, heterocyclic thiols react with perfluoroalkyl iodides with considerably more difficultly than aromatic thiols.

\subsubsection{Photochemical perfluoroalkylation in organic solvents under phase transfer conditions}

Liquid $\mathrm{NH}_{3}$ is a key reaction medium for the reaction of organic thiols with perfluoroalkyl iodides under UV irradiation. However, other solvents have been investigated including alco- hols, acetone, acetonitrile, dioxane, THF, DMF, DMSO, HMPA and so on. Polar aprotic solvents emerge as the best. Biphasic reactions with water work well, particularly with diethyl ether and benzene (Table 4).

Heterocyclic thiolates react more slowly with perfluoroalkyl iodides than thiophenoxides both in liquid ammonia and in organic solvents. Besides, in reactions with heterocyclic thiolates, as well as with thiophenoxides, $\mathrm{CF}_{3} \mathrm{I}$ is a poorer electrophile than $\mathrm{C}_{3} \mathrm{~F}_{7} \mathrm{I}$ - even under biphasic conditions.

\subsubsection{Interaction of thiols with perfluoroalkyl bromides}

Although brominated perfluoroalkanes are cheaper and more readily available than the corresponding iodides, they react more slowly in thioether forming reactions. In general, monobrominated perfluoroalkanes do not react. However, dibromodifluoromethane, bromochlorodifluoromethane as well as 1,2dibromotetrafluoroethane $[170,171]$ do react with metal phenoxides and thiophenoxides via halophilic mechanisms [64], and almost always lead to mixtures of bromo and chloro containing products of mono- and di-substitution. 
Table 4: Reaction of thiophenols $\mathrm{RC}_{6} \mathrm{H}_{4} \mathrm{SH}$ and mercapto heterocycles with $\mathrm{R}_{\mathrm{F}} \mathrm{I}$ under $\mathrm{UV}$ irradiation in organic solvents and biphasic conditions.

\begin{tabular}{|c|c|c|c|c|c|c|}
\hline $\mathrm{R}$ & $\mathrm{R}_{\mathrm{F}}$ & Base & Solvent & Conditions & Yields of $\mathrm{ArSR}_{\mathrm{F}}, \%$ & Ref. \\
\hline \multicolumn{7}{|c|}{ Thiophenols } \\
\hline \multirow[t]{7}{*}{$\mathrm{H}$} & $\mathrm{CF}_{3}$ & $\mathrm{PhSNa}$ & $\mathrm{CH}_{3} \mathrm{OH}$ or acetone & $0-5{ }^{\circ} \mathrm{C}, 30 \mathrm{~min}$ & 57.5 or 79 & [143] \\
\hline & & & $\mathrm{CH}_{3} \mathrm{CN}$ & & 89 & [143] \\
\hline & & $\mathrm{NaOH}$ & $\mathrm{CH}_{3} \mathrm{OH}$ or acetone & $0-5^{\circ} \mathrm{C}, 30 \mathrm{~min}$ & 43 or 49 & [143] \\
\hline & & & $\mathrm{CH}_{3} \mathrm{CN}$ & & 72 & [143] \\
\hline & $\mathrm{CF}\left(\mathrm{CF}_{3}\right)_{2}$ & $\mathrm{Et}_{3} \mathrm{~N}$ & $\mathrm{CH}_{3} \mathrm{CN}$ & $0^{\circ} \mathrm{C}, 30 \mathrm{~min}$ & 88 & [104] \\
\hline & $\mathrm{CF}_{3}$ & $\mathrm{NaOH}$ & $\mathrm{Et}_{2} \mathrm{O} / \mathrm{H}_{2} \mathrm{O}$ & $(\mathrm{Et})_{3} \mathrm{BzN}^{+} \mathrm{Cl}^{-}, 20-25^{\circ} \mathrm{C}, 30 \mathrm{~min}$ & 54 & [167] \\
\hline & $\mathrm{C}_{3} \mathrm{~F}_{7}$ & & & & 78 & [167] \\
\hline \multirow[t]{6}{*}{$4-\mathrm{Cl}$} & $\mathrm{C}_{3} \mathrm{~F}_{7}$ & $\mathrm{ArSNa}^{\mathrm{a}}$ & $\mathrm{CH}_{3} \mathrm{OH}$ or $\mathrm{CH}_{3} \mathrm{CN}$ & $20^{\circ} \mathrm{C}, 30 \mathrm{~min}$ & 61 or 81 & [144] \\
\hline & $\mathrm{CF}_{3}$ & $\mathrm{NaOH}$ & $\mathrm{Et}_{2} \mathrm{O} / \mathrm{H}_{2} \mathrm{O}$ & $(\mathrm{Et})_{3} \mathrm{BzN}^{+} \mathrm{Cl}^{-}, 20-25^{\circ} \mathrm{C}, 30 \mathrm{~min}$ & 61 & [167] \\
\hline & $\mathrm{C}_{3} \mathrm{~F}_{7}$ & & & & 85 & \\
\hline & $i-\mathrm{C}_{3} \mathrm{~F}_{7}$ & & & & 60 & \\
\hline & $\mathrm{C}_{6} \mathrm{~F}_{13}$ & & & & 71 & \\
\hline & $\mathrm{C}_{3} \mathrm{~F}_{7}$ & & $\mathrm{C}_{6} \mathrm{H}_{6} / \mathrm{H}_{2} \mathrm{O}$ & & 68 & [167] \\
\hline \multirow[t]{2}{*}{$4-\mathrm{CH}_{3}$} & $\mathrm{CF}_{3}, \mathrm{C}_{3} \mathrm{~F}_{7}$ & $\mathrm{NaOH}$ & $\mathrm{Et}_{2} \mathrm{O} / \mathrm{H}_{2} \mathrm{O}$ & $(\mathrm{Et})_{3} \mathrm{BzN}^{+} \mathrm{Cl}^{-}, 20-25^{\circ} \mathrm{C}, 30 \mathrm{~min}$ & 58,83 & [167] \\
\hline & $\mathrm{C}_{3} \mathrm{~F}_{7}$ & & $\mathrm{C}_{6} \mathrm{H}_{6} / \mathrm{H}_{2} \mathrm{O}^{\mathrm{b}}$ & & 67 & [167] \\
\hline $4-\mathrm{OCH}_{3}$ & $\mathrm{CF}_{3}$ & $\mathrm{NaOH}$ & $\mathrm{Et}_{2} \mathrm{O} / \mathrm{H}_{2} \mathrm{O}$ & & 52 & [167] \\
\hline $4-\mathrm{CO}_{2} \mathrm{CH}_{3}$ & $\mathrm{C}_{3} \mathrm{~F}_{7}$ & $\mathrm{NaOH}$ & $\mathrm{Et}_{2} \mathrm{O} / \mathrm{H}_{2} \mathrm{O}$ & & 71 & [167] \\
\hline $4-\mathrm{NH}_{2}$ & $\mathrm{CF}_{3}$ & $\mathrm{NH}_{4} \mathrm{OH}$ & $\mathrm{NH}_{4} \mathrm{OH}$ & -60 to $25^{\circ} \mathrm{C}$ & 95 & [168] \\
\hline
\end{tabular}

\begin{tabular}{|c|c|c|c|c|c|c|}
\hline \multicolumn{7}{|c|}{ 2-Mercapto heterocycles ${ }^{c}$} \\
\hline Heterocycle & $\mathrm{R}_{\mathrm{F}}$ & Base & Solvent & Conditions & Yield & Ref. \\
\hline \multirow[t]{4}{*}{ Benzothiazole } & $\mathrm{Cl}\left(\mathrm{CF}_{2}\right)_{4}$ & $\mathrm{NaH}$ & DMF & $70^{\circ} \mathrm{C}, 10 \mathrm{~h}$ & 41.2 & [169] \\
\hline & $\mathrm{Cl}\left(\mathrm{CF}_{2}\right)_{6}$ & $\mathrm{NaH}$ & DMF & $70^{\circ} \mathrm{C}, 10 \mathrm{~h}$ & $61.6^{d}$ & [169] \\
\hline & $\mathrm{C}_{6} \mathrm{~F}_{13}$ & $\mathrm{NaH}$ & DMF & $70^{\circ} \mathrm{C}, 10 \mathrm{~h}$ & 53.6 & [169] \\
\hline & $\mathrm{C}_{8} \mathrm{~F}_{17}$ & & & & 71.6 & \\
\hline \multirow[t]{3}{*}{ Benzimidazole } & $\mathrm{Cl}\left(\mathrm{CF}_{2}\right)_{4}$ & $\mathrm{NaH}$ & DMF & $70^{\circ} \mathrm{C}, 10 \mathrm{~h}$ & $40.6^{\mathrm{e}}$ & [169] \\
\hline & $\mathrm{Cl}\left(\mathrm{CF}_{2}\right)_{6}$ & $\mathrm{NaH}$ & DMF & $70^{\circ} \mathrm{C}, 10 \mathrm{~h}$ & 38.2 & [169] \\
\hline & $\mathrm{C}_{6} \mathrm{~F}_{13}, \mathrm{C}_{8} \mathrm{~F}_{17}$ & $\mathrm{NaH}$ & DMF & $70^{\circ} \mathrm{C}, 10 \mathrm{~h}$ & $77.6,78.2$ & [169] \\
\hline Benzoxazole & $\mathrm{Cl}\left(\mathrm{CF}_{2}\right)_{6}$ & $\mathrm{NaH}$ & DMF & $70^{\circ} \mathrm{C}, 10 \mathrm{~h}$ & 15.0 & [169] \\
\hline
\end{tabular}

${ }^{\mathrm{a}} \mathrm{At} \mathrm{ArSH}+\mathrm{Et}_{2} \mathrm{NH}$ or $\mathrm{Et}_{3} \mathrm{~N}$ for $3 \mathrm{~h}$, the yields are $37 \%$ and $28 \%$, respectively.

bIn $\mathrm{CH}_{2} \mathrm{Cl}_{2} / \mathrm{H}_{2} \mathrm{O}$ or $\mathrm{CHCl}_{3} / \mathrm{H}_{2} \mathrm{O}$ the yields are $50 \%$ and $55 \%$, respectively.

cYields of products are resulted taking into account a conversion of $\mathrm{R}_{\mathrm{F}} \mathrm{I}$.

${ }^{\mathrm{d}}$ In presence of $(t-\mathrm{Bu})_{2} \mathrm{~N}-\mathrm{O}^{\circ}$ the yield is $18.6 \%$.

en presence of $(t-\mathrm{Bu})_{2} \mathrm{~N}-\mathrm{O}^{\circ}$ the yield is $8.6 \%$.

Their lower reactivity [88] is largely due to the greater dissociation energy of the $\mathrm{C}-\mathrm{Br}$ bond $\left(55 \mathrm{kcal} / \mathrm{mol}\right.$ for $\mathrm{CF}_{3} \mathrm{Br}$ ) compared to $\mathrm{C}-\mathrm{I}\left(28 \mathrm{kcal} / \mathrm{mol}\right.$ for $\left.\mathrm{CF}_{3} \mathrm{I}\right)$ [172]. In addition, $\mathrm{CF}_{3} \mathrm{Br}$ has a higher reduction potential than $\mathrm{CF}_{3} \mathrm{I}$ and prefers to receive two rather than one electron on reduction [173].

Nevertheless, it was found [174] that UV irradiation of thiolates in liquid ammonia or dimethylformamide with perfluoroalkyl bromides does result in the formation of the corresponding perfluoroalkyl sulfides as shown in Scheme 45.
Thiols with electron-donating substituents give reasonable yields, whilst $p$-chlorothiophenol produces the corresponding trifluoromethyl sulfide in low yield $(\sim 3-5 \%)$, although better yields are obtained when iodide salts are used as catalysts [175].

Wakselman et al., have shown [176] that liquid $\mathrm{C}_{6} \mathrm{~F}_{13} \mathrm{Br}$ reacts with thiolates without any irradiation, whereas bubbling gaseous $\mathrm{CF}_{3} \mathrm{Br}$ through a DMF solutions of thiolates at $20^{\circ} \mathrm{C}$ or heating such mixtures in an autoclave $\left(80^{\circ} \mathrm{C}\right)$ does not produce trifluoromethyl sulfides. Reactions between thiophenoxides and 


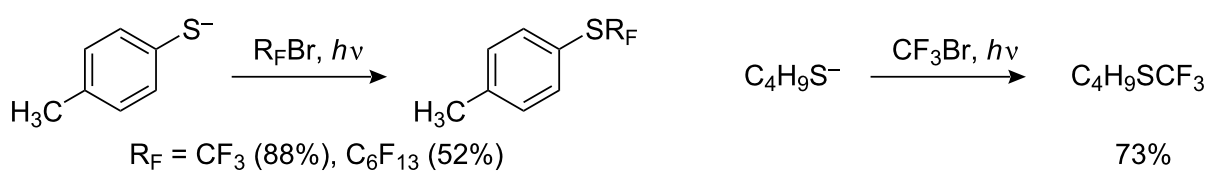

Scheme 45: Perfluoroalkylation of thiolates with $\mathrm{CF}_{3} \mathrm{Br}$ under UV irradiation.

$\mathrm{CF}_{3} \mathrm{Br}$ are successful if carried out under pressure $\left(\mathrm{CF}_{3} \mathrm{Br}\right.$ 2-3 atm) in DMF at $20^{\circ} \mathrm{C}$ [176-178]. However, even under these conditions only thiols containing electron-donating groups in the para-position give high yields. All ethers (Table 5), even those with electron-donating groups in the ortho- and metapositions show very poor reactivity.

The best results arise from a combination of two factors - a pressure of $\mathrm{CF}_{3} \mathrm{Br}$ and $\mathrm{UV}$ irradiation $[158,179]$. Results are given in Tables 6-8. In these cases the influence of the solvent is obvious. For example, $p$-chlorothiophenol reacts poorly with $\mathrm{CF}_{3} \mathrm{Br}$ and 4-chloro-4'-trifluoromethylsulfanyldiphenyl sulfide is obtained as a byproduct presumably as the result of photo- substitution of chlorine in 4-trifluoromethylsulfanylchorobenzene by an $\mathrm{S}_{\mathrm{RN}} 1$ mechanism. HMPA suppressed this side-reaction (similar to iodobenzene with potassium diethyl phosphite [180]) and promoted trifluoromethylation (Table 6).

The reaction solvent is important and the yield of the trifluoromethylated product decreases in the following sequence: HMPA $>$ DMF $>\mathrm{CH}_{3} \mathrm{CN}>\mathrm{N}$-methyl pyrrolidone $>$ sulfolane [179] (Table 6). The efficiency of the combined influence of irradiation and pressure of $\mathrm{CF}_{3} \mathrm{Br}$ is presented in Table 7 .

As can be seen from the data in (Table 6 and Table 7), in spite of increased product yields in general, the selectivity remains

Table 5: Yields of $\mathrm{CF}_{3} \mathrm{Br}$ reaction with thiophenoxides in DMF at $20{ }^{\circ} \mathrm{C}$ under pressure (2-3 atm) [178].

\begin{tabular}{llllllllll} 
Substituents in thiophenols & $\mathrm{H}$ & $4-\mathrm{CH}_{3}$ & $4-\mathrm{OCH}_{3}$ & $3-\mathrm{OCH}_{3}$ & 2- $-\mathrm{OCH}_{3}$ & 3- $-\mathrm{NH}_{2}$ & 4-Cl & 3-CF & 4- $-\mathrm{NHAc}_{3}$ \\
\hline Yields of $\mathrm{ArSCF}_{3}, \%$ & 62 & 75 & 83 & 40 & 7 & 23 & 34 & 13 & 9
\end{tabular}

Table 6: Reactions of thiophenoxides with $\mathrm{CF}_{3} \mathrm{Br}$ under UV irradiation and pressure of reaction gas [179].

\begin{tabular}{|c|c|c|c|c|c|c|c|}
\hline $\mathrm{R}$ & Solvent & Base & $p($ atm $)$ & $T\left({ }^{\circ} \mathrm{C}\right)$ & $\begin{array}{l}\text { Irradiation } \\
\text { time, }(\mathrm{h})\end{array}$ & $\begin{array}{l}\text { Conversion of } \\
\mathrm{ArSH},(\%)\end{array}$ & $\begin{array}{l}\text { Isolated yields of } \\
\text { ArSCF }_{3}(\%)\end{array}$ \\
\hline $4-\mathrm{CH}_{3}$ & DMF & $\mathrm{Et}_{3} \mathrm{~N}$ & $4-5$ & $10-13$ & 1.5 & & 82 \\
\hline $4-\mathrm{NH}_{2}$ & DMF & $\mathrm{Et}_{3} \mathrm{~N}$ & $4.5-6$ & $10-20$ & 2 & & 76.4 \\
\hline $3-\mathrm{NH}_{2}$ & HMPA & morpholine & $3-4$ & $17-19$ & 3.25 & & $63.5^{a}$ \\
\hline 4-NHCOMe & DMF & $\mathrm{Et}_{3} \mathrm{~N}$ & 3.5 & 19 & 2.7 & & 69 \\
\hline \multirow[t]{2}{*}{$4-\mathrm{NHCO}_{2} \mathrm{Me}$} & DMF & $\mathrm{Et}_{3} \mathrm{~N}$ & $4.5-5$ & $15-25$ & 1.2 & 63 & 55.5 \\
\hline & HMPA & morpholine & $2-5$ & $8-10$ & 2.5 & 73 & 83.6 \\
\hline \multirow[t]{7}{*}{$4-\mathrm{Cl}$} & $\mathrm{CH}_{3} \mathrm{CN}$ & $\mathrm{Et}_{3} \mathrm{~N}$ & $3-3.5$ & $15-18$ & 2.8 & 53 & $43^{a}$ \\
\hline & DMF & $\mathrm{Et}_{3} \mathrm{~N}$ & $3-3.5$ & 14 & 1.2 & 100 & $48^{a}$ \\
\hline & HMPA & $\mathrm{Et}_{3} \mathrm{~N}$ & 4 & $8-10$ & 1 & 100 & 69 \\
\hline & HMPA & morpholine & $3-4$ & $14-16$ & 3.5 & 97 & 62.5 \\
\hline & HMPA & morpholine & $3-4.5$ & $29-30$ & 3 & 36 & 46 \\
\hline & Sulfolane & morpholine & 3.5 & 23 & 2 & 19.5 & 5.4 \\
\hline & N-Methyl pyrrolidone & morpholine & 3.5 & 17 & 2.2 & 35.5 & 14.3 \\
\hline
\end{tabular}

aDetermined by GLC. 
Table 7: Comparison of $\mathrm{RC}_{6} \mathrm{H}_{4} \mathrm{SCF}_{3}$ yields, obtained under a pressure of $\mathrm{CF}_{3} \mathrm{Br}$ with and without UV irradiation (DMF, $p=3-5 \mathrm{~atm}, T=$ $\left.10-20{ }^{\circ} \mathrm{C}\right)$.

\begin{tabular}{llll} 
& \multicolumn{1}{c}{$\begin{array}{l}\text { Irradiation } \\
\text { time, } \mathrm{h}\end{array}$} & \multicolumn{2}{c}{ Yields of $\mathrm{RC}_{6} \mathrm{H}_{4} \mathrm{SCF}_{3}, \%$} \\
\cline { 3 - 4 } & & Irradiation & $\begin{array}{l}\text { Without } \\
\text { irradiation }\end{array}$ \\
& 1.5 & 82 & 75 \\
$4-\mathrm{CH}_{3}$ & 2.2 & 56 & 23 \\
$3-\mathrm{NH}_{2}$ & 4 & 72.5 & \\
$4-\mathrm{NHCOCH}$ & 2.7 & 69 & 9 \\
$4-\mathrm{Cl}$ & 1.2 & 48 & 34 \\
\hline
\end{tabular}

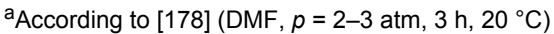

about the same. The best results are found with thiophenols, containing electron-donating substituents in the para-position. It is possible to increase the effectiveness of the $p$-chlorothiophenol reaction to $\sim 70 \%$ by suppression of by-product formation (4-Cl- $\left.\mathrm{C}_{6} \mathrm{H}_{4} \mathrm{SC}_{6} \mathrm{H}_{4} \mathrm{SCF}_{3}-4\right)$ and by using HMPA as solvent.

Trifluoromethylation of easily oxidizable aminothiophenols can be conducted by a modified procedure. The required thiophenoxides are prepared directly prior to irradiation by reduction of the corresponding dinitrophenyl disulfides with $\mathrm{Li} /$ liquid $\mathrm{NH}_{3}$ (Table 8), in much the same way as the described above for $\mathrm{R}_{\mathrm{F}} \mathrm{I}$ $[158,159]$.

Table 8: Preparation of aminophenyl trifluoromethyl sulfides with $\mathrm{CF}_{3} \mathrm{Br}$ (3-7 atm) and UV irradiation with preliminary reduction of dinitrodiphenyl disulfides [179].

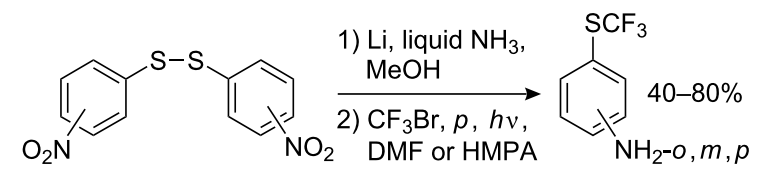

\begin{tabular}{llllll}
\hline $\begin{array}{l}\text { Location } \\
\text { of } \mathrm{NO}_{2} \\
\left(\mathrm{NH}_{2}\right)\end{array}$ & Solvents & $p(\mathrm{~atm})$ & $T\left({ }^{\circ} \mathrm{C}\right)$ & $\begin{array}{l}\text { Irradiation } \\
\text { time, } \mathrm{h}\end{array}$ & $\begin{array}{l}\text { Yields of } \\
\text { products, } \\
\%\end{array}$ \\
\hline$o-$ & DMF & $4.6-6$ & $10-13$ & 7.75 & 40.9 \\
$m-$ & DMF & $3-3.5$ & $8-10$ & 2.2 & $56^{\mathrm{a}}$ \\
& DMF & $3-6$ & $10-14$ & 4 & $72.5^{\mathrm{a}}$ \\
& DMF & $4-6$ & $12-19$ & 6.8 & 80.8 \\
& HMPA & $3-5$ & $8-10$ & 3 & $71.8^{\mathrm{a}}$ \\
\hline- & DMF & $5-6$ & $15-20$ & 5 & 80.3 \\
\hline
\end{tabular}

asolated as the acetyl derivative.

Due to greater UV stability of $\mathrm{CF}_{3} \mathrm{Br}$ compared to $\mathrm{CF}_{3} \mathrm{I}$, it is possible to increase the irradiation time, with a beneficial effect on the product yield.

\subsubsection{Other methods of initiating}

From the knowledge that the reaction mechanism is a singleelectron transfer process involving $\mathrm{R}_{\mathrm{F}} \cdot$ radicals, alternative methods to photochemical initiation have been developed (see sections 4.1.1.-4.1.4.), e.g., the electrochemical reduction of perfluoroalkyl halogenides $[173,181]$. In the presence of thiolate anions the resulting electrophilic radicals react $[182,183]$ to give aryl perfluoroalkyl sulfides (Table 9).

Table 9: Formation of aryl perfluoroalkyl sulfides by electrochemical initiated reactions of $\mathrm{ArS}^{-}$with $\mathrm{R}_{\mathrm{F}} \mathrm{Hlg}$.

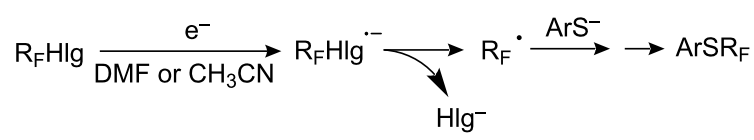

\begin{tabular}{|c|c|c|c|c|}
\hline \multicolumn{2}{|l|}{ Reagents } & \multicolumn{2}{|c|}{ Yield of $\mathrm{ArSR}_{\mathrm{F}}, \%$} & \multirow[t]{2}{*}{ Ref. } \\
\hline $\mathrm{ArS}^{-}$ & $\mathrm{R}_{\mathrm{F}} \mathrm{Hlg}$ & $\begin{array}{l}\text { On } \\
\text { substrate }\end{array}$ & $\begin{array}{l}\text { On } \\
\text { current }\end{array}$ & \\
\hline$p-\mathrm{CH}_{3} \mathrm{C}_{6} \mathrm{H}_{4} \mathrm{~S}^{-}$ & $\mathrm{CF}_{3} \mathrm{I}$ & 55 & 300 & [182] \\
\hline$p-\mathrm{CH}_{3} \mathrm{C}_{6} \mathrm{H}_{4} \mathrm{~S}^{-}$ & $\mathrm{C}_{3} \mathrm{~F}_{7} \mathrm{I}$ & 77 & 270 & [182] \\
\hline$p-\mathrm{CH}_{3} \mathrm{C}_{6} \mathrm{H}_{4} \mathrm{~S}^{-}$ & $\mathrm{CF}_{3} \mathrm{Br}$ & $40^{\mathrm{a}}$ & 200 & [182] \\
\hline$p-\mathrm{CH}_{3} \mathrm{C}_{6} \mathrm{H}_{4} \mathrm{~S}^{-}$ & $\mathrm{C}_{8} \mathrm{~F}_{17} \mathrm{Br}$ & 63 & 360 & [182] \\
\hline$p-\mathrm{ClC}_{6} \mathrm{H}_{4} \mathrm{~S}^{-}$ & $\mathrm{CF}_{3} \mathrm{I}$ & 75 & 250 & [182] \\
\hline$p-\mathrm{ClC}_{6} \mathrm{H}_{4} \mathrm{~S}^{-}$ & $\mathrm{CF}_{3} \mathrm{Br}$ & $61^{b}$ & 98 & [182] \\
\hline$p-\mathrm{ClC}_{6} \mathrm{H}_{4} \mathrm{~S}^{-}$ & $\mathrm{C}_{3} \mathrm{~F}_{7} \mathrm{I}$ & 82 & 450 & [182] \\
\hline$p-\mathrm{ClC}_{6} \mathrm{H}_{4} \mathrm{~S}^{-}$ & $\mathrm{CF}_{3} \mathrm{I}$ & 60 & 300 & [181] \\
\hline$p-\mathrm{CH}_{3} \mathrm{OCONHC}{ }_{6} \mathrm{H}_{4} \mathrm{~S}^{-}$ & $\mathrm{CF}_{3} \mathrm{I}$ & 33 & 160 & [181] \\
\hline Thiazole-2-S- & $\mathrm{C}_{6} \mathrm{~F}_{13} \mathrm{I}$ & $64^{c}$ & & [184] \\
\hline
\end{tabular}

aWith a carbon-glass electrode a yield is $77 \%$.

bWith a carbon-glass electrode.

In the presence of $p-\mathrm{O}_{2} \mathrm{NC}_{6} \mathrm{H}_{4} \mathrm{CN}$.

The good yields for electrochemical perfluoroalkylation (especially $>100 \%$ electrochemical yield) are consistent with a radical-chain process.

Perfluoroalkyl iodides are better substrates than the bromides which give lower yields in these electrochemical reactions (Table 9). Such electrochemically initiated reactions are described in detail in a review [35].

Another method of catalytic generation of $\mathrm{R}_{\mathrm{F}}{ }^{\cdot}$ radicals involves electron-transfer from a nucleophile to a perfluoroalkyl halide, in this case using the dimethyl dipyridinium salt (methylviologen, $\mathrm{MV}^{2+}$ ) as a catalyst. This dication is initially reduced to a radical cation, which then transfers an electron to a perfluoroalkyl iodide [185] to generate $\mathrm{R}_{\mathrm{F}}{ }^{\bullet}$ (Scheme 46). A small amount of $\mathrm{MV}^{2+}$ (7\% relative to $\left.\mathrm{ArSH}\right)$ is sufficient for quantitative transformation of thiols into aryl perfluoroalkyl sulfides (Table 10). 


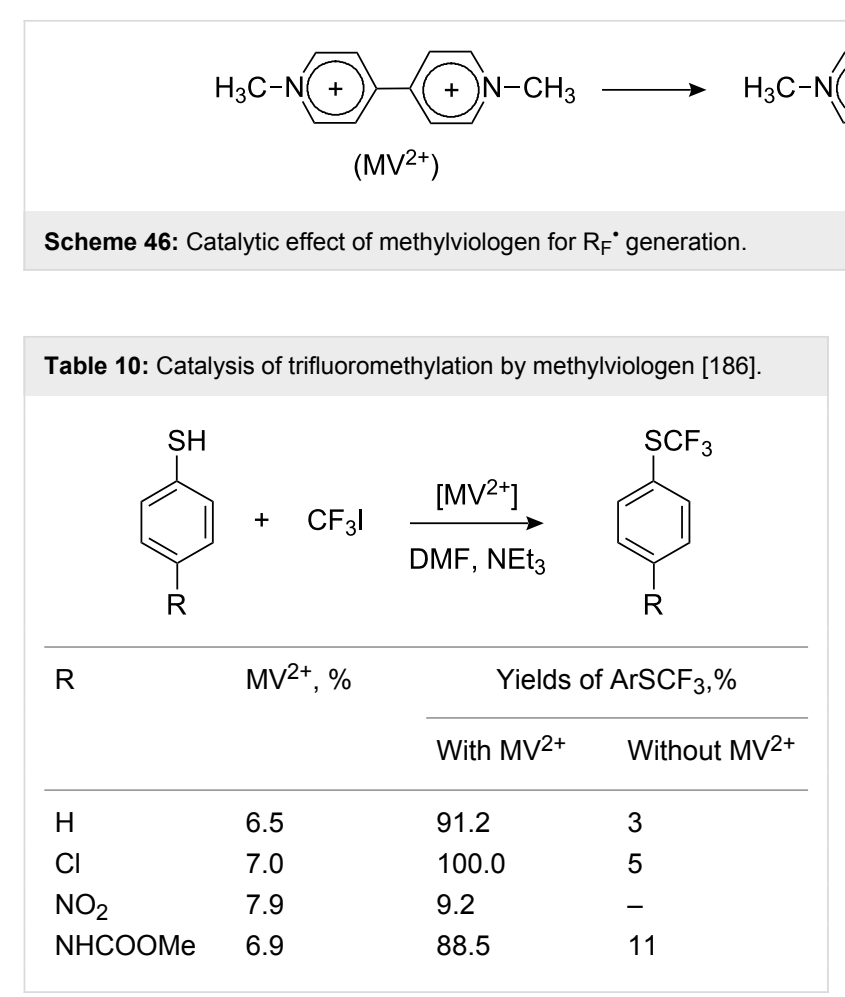

It should be noted that over-reduction of such halides will generate $\mathrm{R}_{\mathrm{F}}^{-}$anions rather than the desired $\mathrm{R}_{\mathrm{F}}{ }^{-}$radicals. For example, tetrakis(dimethylamino)ethylene reacts with $\mathrm{R}_{\mathrm{F}} \mathrm{I}$ to form the perfluoroalkyl anion which acts as a nucleophilic $\mathrm{R}_{\mathrm{F}}$-alkylation agent for organic and inorganic substrates [187].

The use of any catalyst in the case of perfluoroalkyl iodides is of more theoretical interest, although the method can be applied in the case of poorly reactive thiophenols. In general these reactions work well (see section 4.1.6.) in common organic solvents or under biphasic conditions $[188,189]$. Reactions with perfluoroalkyl bromides are more sluggish. Only compounds with long perfluoroalkyl chains such as $\mathrm{C}_{6} \mathrm{~F}_{13} \mathrm{Br}$ [178] react readily with thiolates. In the reaction of gaseous $\mathrm{CF}_{3} \mathrm{Br}$ with thiophenols special procedures are required (see section 4.1.4.): UV irradiation [174], pressure [178] and electrochemical stimulation [182]. Moreover, thiophenols with electron-donating substituents in the para-position give the best results. Combined pressure and irradiation $[158,179]$ improved yields only slightly and requires special equipment. A detailed study of catalytic stimulation in reactions of bromo- and chloro-containing freons $\mathrm{R}_{\mathrm{F}} \mathrm{X}$ with thiols is necessary.

The decreased reactivity of $\mathrm{CF}_{3} \mathrm{Br}$ as compared to $\mathrm{CF}_{3} \mathrm{I}$ can be explained, first of all, by the higher reduction potential $(-2.07 \mathrm{~V}$ against $-1.52 \mathrm{~V}$ for $\mathrm{CF}_{3} \mathrm{I}$ on a glass-carbon cathode), and secondly, by the fact that the $\mathrm{CF}_{3} \cdot$ radical has a reduction potential $(-1.80 \mathrm{~V})$ close to that of $\mathrm{CF}_{3} \mathrm{Br}$ [173]. Thus trifluoro- methyl bromide in reactions with nucleophiles or on a cathode surface accepts two electrons and is transformed to $\mathrm{CF}_{3}{ }^{-}$and therefore does not react with thiolates. The $\mathrm{SO}_{2}{ }^{-\bullet}$ radical anion can act as an electron mediator in such reactions. This radical anion, generated by chemical [190-193] or electrochemical $[194,195]$ methods, causes a single-electron reduction of $\mathrm{CF}_{3} \mathrm{Br}$ with the formation of the necessary trifluoromethyl radical. Thus, the influence of $\mathrm{SO}_{2}{ }^{-\bullet}$ sources $\left(\mathrm{Na}_{2} \mathrm{~S}_{2} \mathrm{O}_{4}, \mathrm{HOCH}_{2} \mathrm{SO}_{2} \mathrm{Na}\right.$ or $\mathrm{SO}_{2}$ in presence $\mathrm{Zn}$ and $\mathrm{Na}_{2} \mathrm{HPO}_{4}$ or $\mathrm{HCOONa}$ ) on trifluoromethyl bromide in DMF in the presence of diaryl disulfides $[193,196]$ leads to the formation of the corresponding trifluoromethyl sulfides, often in high yields (Scheme 47).

$$
\mathrm{RS}-\mathrm{SR}+\mathrm{CF}_{3} \mathrm{Br} \underset{\mathrm{DMF}}{\stackrel{\left[\mathrm{SO}_{2}^{-\cdot}\right]}{\longrightarrow}} \mathrm{RSCF}_{3} \quad 65-90 \%
$$

$\mathrm{R}=\mathrm{Ph}, \mathrm{Bu}, \mathrm{CH}_{2} \mathrm{COOEt}, 2-\mathrm{NH}_{2}-3-\left(2,4,6-\mathrm{Cl}_{3} \mathrm{C}_{6} \mathrm{H}_{2}\right)^{-5}-\mathrm{CN}-$ pyrazolyl

Scheme 47: $\mathrm{SO}_{2}^{-\bullet}$ catalyzed trifluoromethylation.

Related transformations with various $\mathrm{SO}_{2}{ }^{-\bullet}$ sources involving $\mathrm{R}_{\mathrm{F}} \mathrm{I}$ and $\mathrm{CF}_{2} \mathrm{ClBr}, \mathrm{CFCl}_{2}-\mathrm{CF}_{2} \mathrm{Cl}$ in the reactions with diaryl disulfides [197] and diselenides have been reported [198]. Electrochemical studies involving the $\mathrm{SO}_{2}{ }^{-\bullet}$ radical anion prove that the electron transfer to $\mathrm{CF}_{3} \mathrm{Br}$ takes place at a reduction potential of the mediator between -0.9 and $-1.0 \mathrm{~V}$ which prevents the transfer of a second electron to $\mathrm{CF}_{3}{ }^{\bullet}$ and the generation of $\mathrm{CF}_{3}{ }^{-}$[199]. Therefore electrochemical reduction in the presence of sulfur dioxide allows the trifluoromethylation of thiophenols with the less reactive, but more readily available trifluoromethyl bromide (Scheme 48).

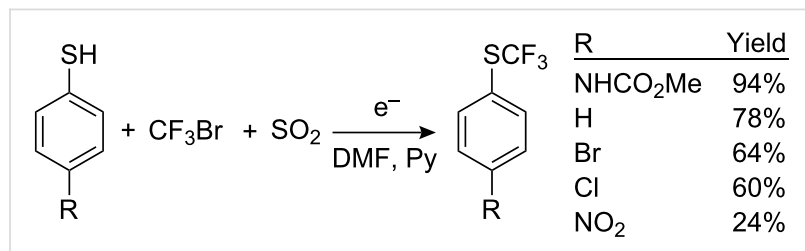

Scheme 48: Electrochemical reduction of $\mathrm{CF}_{3} \mathrm{Br}$ in the presence of $\mathrm{SO}_{2}[199,200]$.

Although 4-nitrothiophenol is a very poor substrate (see section 4.1.1. and Table 11), it reacts with perfluoroalkyl iodides to afford 4-perfluoroalkylsulfanylnitrobenzenes in presence of 
$\mathrm{NaH}$ in DMF in almost quantitative yields [201], presumably via "hydride" catalysis.

The catalytic influence of $\mathrm{SO}_{2}$ on the reaction of $\mathrm{ArS}^{-}$with $\mathrm{CF}_{3} \mathrm{Br}$ is not limited to the activation of the initial bromide. Sulfur dioxide can oxidize the radical anion $\mathrm{ArSCF}_{3}{ }^{-}$, i.e., it can affect the rate determining step of the process [189] (Scheme 49).

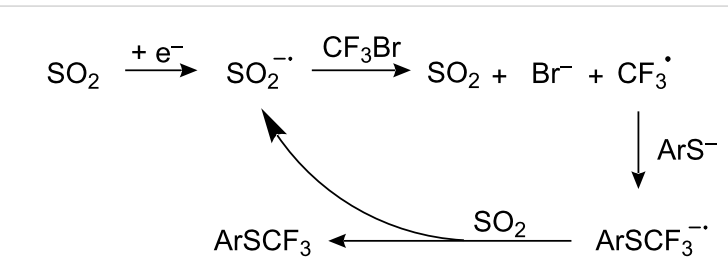

Scheme 49: Participation of $\mathrm{SO}_{2}$ in the oxidation of $\mathrm{ArSCF}_{3}{ }^{-*}$.

This dual influence of sulfur dioxide contributes to the overall efficiency of these reactions.

By comparing the possibility of two mediators $\left(\mathrm{SO}_{2}\right.$ and $\left.\mathrm{MV}\right)$, Koshechko et al., [202] have shown that the radical cation $\mathrm{MV}^{+\bullet}\left(\mathrm{E}_{\mathrm{p}}=-0.4 \mathrm{~V}\right)$ easily reduces $\mathrm{SO}_{2}\left(\mathrm{E}_{\mathrm{p}}=-0.9 \mathrm{~V}\right)$ to its radical anion which in turn activates $\mathrm{CF}_{3} \mathrm{Br}$. Thus, a combination of both mediators generates an electron transfer cascade (Scheme 50).

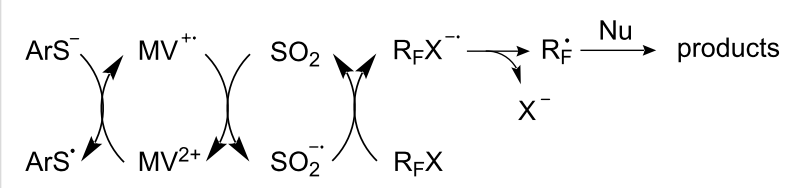

Scheme 50: Electron transfer cascade involving $\mathrm{SO}_{2}$ and $\mathrm{MV}$.

Thus, bubbling $\mathrm{CF}_{3} \mathrm{Br}$ into a solution of thiophenol or thiocresol in DMF containing pyridine, $\mathrm{SO}_{2}$ and a catalytic amount of $\mathrm{MV}^{2+} 2 \mathrm{I}^{-}$, results in the formation of the corresponding aryl trifluoromethyl sulfides in moderate to good yields $(40-70 \%)[202]$.

Similar reactions with $\mathrm{SO}_{2}$, where $\mathrm{KI}$ or $\mathrm{I}_{2}$ were used instead of $\mathrm{MV}^{2+}$ have been carried out [202], however, the yields of $\mathrm{PhSCF}_{3}$ were reduced. The catalytic effect of iodide ion was discovered from UV irradiation of a reaction mixture of p-chlorothiophenol with $\mathrm{CF}_{3} \mathrm{Br}$ in different solvents [175].

The $\mathrm{MV}^{2+} / \mathrm{SO}_{2}$ system is effective for reactions with Freons, particularly those with $\mathrm{C}-\mathrm{Cl}$ bonds such as Freon-113 $\left(\mathrm{CF}_{2} \mathrm{Cl}-\right.$ $\mathrm{CFCl}_{2}$ ) [202].
A good example of the catalytic properties of $\mathrm{SO}_{2}$ has recently been shown in the reaction of 1,2-dibromotetrafluoroethane with thiophenoxides [203]. It is known that these reactions $\mathrm{ArSCF}_{2} \mathrm{CF}_{2} \mathrm{Br}$ and a significant amount of $\mathrm{ArSCF}_{2} \mathrm{CF}_{2} \mathrm{H}$ are produced. The presence of $\mathrm{SO}_{2}$ in the reaction promotes a $\mathrm{S}_{\mathrm{RN}} 1$ process which results in quantitative yields of $\mathrm{ArSCF}_{2} \mathrm{CF}_{2} \mathrm{Br}$ without the byproduct $\mathrm{ArSCF}_{2} \mathrm{CF}_{2} \mathrm{H}$.

\subsubsection{Spontaneous perfluoroalkylation of thiols without initiators}

Since Feiring reported in 1984 that reactions of thiolate anions and perfluoroalkyl iodides can occur spontaneously without any initiator [188], the method has been extensively investigated and the reaction conditions optimized (Table 11 and Table 12). Reactions times, for example, are shortened with heating $\left(60-70{ }^{\circ} \mathrm{C}\right)[204]$.

Later it was found that these types of reaction can be made to proceed considerably easier and quicker (Table 12). In acetonitrile or DMF the majority of thiophenolates react rapidly with $\mathrm{C}_{3} \mathrm{~F}_{7} \mathrm{I}$ at room temperature (from $10-15 \mathrm{~min}$ to $2-3 \mathrm{~h}$ ). However, for spontaneous reaction many factors are involved such as carrying out the reaction in the dark, temperature, solvent etc. This is discussed in more detail in section 4.1.7.

\subsubsection{Reaction mechanism}

The stages of $S$-perfluoroakylation [22,35,143,188,208] can be represented as follows (Scheme 51):

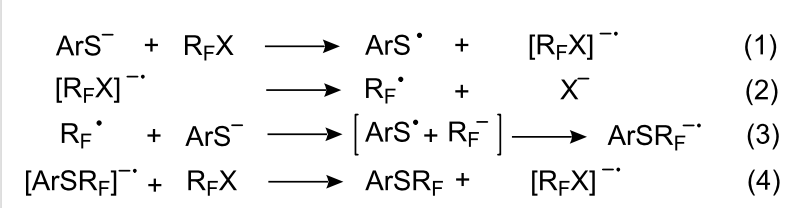

Scheme 51: Four stages of the $\mathrm{S}_{\mathrm{RN}} 1$ mechanism for thiol perfluoroalkylation.

The peculiar behavior of 4-nitrothiophenol [143,146] and 4-hydroxypyrimidine-2-thiol [145] unlike the more electronegative $p$ - $\mathrm{SO}_{2} \mathrm{CF}_{3}$ - and $o-\mathrm{SO}_{2} \mathrm{CHF}_{2}$-thiophenols [143] is presumably related to the ability of the nitro- and carbonyl groups to stabilize the mercapto-radicals in the radical ion pairs $\left[{ }^{\circ} \mathrm{O}_{2} \mathrm{NArS}+\mathrm{R}_{\mathrm{F}}{ }^{-}\right]$and $\left[{ }^{\circ} \mathrm{O}=\mathrm{CArS}+\mathrm{R}_{\mathrm{F}}{ }^{-}\right]$. As a result, these radicals are less reactive, although at higher temperatures an increase in their activity is observed.

The participation of radicals is supported by the fact that the addition of nitrobenzene [178] or di-tert-butylnitroxide [169] 


\begin{tabular}{|c|c|c|c|c|c|c|}
\hline $\mathrm{R}$ & $\mathrm{SH},\left(\mathrm{SCat}^{+}\right)$ & $\mathrm{R}_{\mathrm{F}}$ & Base & Reaction conditions & Yields of $\mathrm{ArSR}_{\mathrm{F}}, \%$ & Ref. \\
\hline \multicolumn{7}{|c|}{ Thiophenols } \\
\hline $\mathrm{H}$ & $\mathrm{SNa}$ & $\mathrm{C}_{8} \mathrm{~F}_{17}$ & - & $\mathrm{DMF}, 25^{\circ} \mathrm{C}, 17 \mathrm{~h}$ & 90 & [188] \\
\hline $\mathrm{H}$ & $\mathrm{SNa}$ & $\mathrm{C}_{8} \mathrm{~F}_{17}$ & - & $\mathrm{DMF}, 25^{\circ} \mathrm{C}, 17 \mathrm{~h}+$ norbornene & 77 & [188] \\
\hline $\mathrm{H}$ & $\mathrm{SNa}$ & $\mathrm{C}_{8} \mathrm{~F}_{17}$ & - & $\mathrm{DMF}, 25^{\circ} \mathrm{C}, 17 \mathrm{~h}+$ styrene & 0 & [188] \\
\hline $\mathrm{H}$ & $\mathrm{SNa}$ & $\mathrm{CF}\left(\mathrm{CF}_{3}\right)_{2}$ & - & $\mathrm{DMF}, 25^{\circ} \mathrm{C}, 17 \mathrm{~h}$ & 76 & [188] \\
\hline $\mathrm{H}$ & $\mathrm{SNBu}_{4}$ & $\mathrm{C}_{6} \mathrm{~F}_{13}$ & - & $\mathrm{CH}_{2} \mathrm{Cl}_{2} / \mathrm{H}_{2} \mathrm{O}, 40^{\circ} \mathrm{C}, 4 \mathrm{~h}$ & 48 & [188] \\
\hline $\mathrm{H}$ & $\mathrm{SNBu}_{4}$ & $\mathrm{C}_{6} \mathrm{~F}_{13}$ & - & $\mathrm{C}_{6} \mathrm{H}_{6} / \mathrm{H}_{2} \mathrm{O}, 25^{\circ} \mathrm{C}, 2.5 \mathrm{~h}$ & $76^{a}$ & [188] \\
\hline $\mathrm{H}$ & & $\mathrm{R}\left(\mathrm{CF}_{2}\right)_{n}$ & & DMF, conditions are not presented & $56-87$ & [205] \\
\hline $4-\mathrm{NH}_{2}$ & $\mathrm{SH}$ & $\mathrm{C}_{2} \mathrm{~F}_{5}$ & $\mathrm{~K}_{2} \mathrm{CO}_{3}$ & DMF, $10^{\circ} \mathrm{C}$ & 84 & [206] \\
\hline $4-\mathrm{F}$ & $\mathrm{SNa}$ & $\mathrm{C}_{10} \mathrm{~F}_{21}$ & - & $\mathrm{DMF}, 70^{\circ} \mathrm{C}, 1 \mathrm{~h}$ & 97 & [204] \\
\hline $4-\mathrm{F}$ & $\mathrm{SNa}$ & $\left.\mathrm{CF}_{2}\right)_{4} \mathrm{I}$ & - & DMF, $25^{\circ} \mathrm{C}, 12 \mathrm{~h}, 60^{\circ} \mathrm{C}, 1 \mathrm{~h}$ & \multicolumn{2}{|l|}{$86^{b}$} \\
\hline $4-\mathrm{Cl}$ & $\mathrm{SNa}$ & $\left(\mathrm{CF}_{2}\right)_{8} \mathrm{I}$ & - & \multicolumn{3}{|l|}{$\mathrm{DMF}, 50^{\circ} \mathrm{C}, 6 \mathrm{~h}$} \\
\hline $\mathrm{H}$ & $\mathrm{SH}$ & $\mathrm{C}_{4} \mathrm{~F}_{9}$ & $\mathrm{NaH}$ & DMF, $20-25^{\circ} \mathrm{C}, 17-18 \mathrm{~h}$ & 66 & [201] \\
\hline $4-\mathrm{CH}_{3}$ & $\mathrm{SH}$ & $\mathrm{C}_{4} \mathrm{~F}_{9}$ & $\mathrm{NaH}$ & DMF, $20-25^{\circ} \mathrm{C}, 17-18 \mathrm{~h}$ & 77 & [201] \\
\hline $4-\mathrm{OH}$ & $\mathrm{SH}$ & $\mathrm{C}_{4} \mathrm{~F}_{9}$ & $\mathrm{NaH}$ & DMF, $20-25^{\circ} \mathrm{C}, 17-18 \mathrm{~h}$ & 30 & [201] \\
\hline $4-\mathrm{Cl}$ & $\mathrm{SH}$ & $\mathrm{C}_{4} \mathrm{~F}_{9}$ & $\mathrm{NaH}$ & $\mathrm{DMF}, 20-25^{\circ} \mathrm{C}, 17-18 \mathrm{~h}$ & 83 & [201] \\
\hline $4-\mathrm{NO}_{2}$ & $\mathrm{SH}$ & $\mathrm{C}_{4}-\mathrm{C}_{8}$ & $\mathrm{NaH}$ & DMF, $20-25^{\circ} \mathrm{C}, 17-18 \mathrm{~h}$ & $93-99$ & [201] \\
\hline $\mathrm{F}_{5}$ & $\mathrm{SCu}$ & $\mathrm{CF}_{2}=\mathrm{CF}$ & - & $\mathrm{DMAC}, 70^{\circ} \mathrm{C}, 20 \mathrm{~h}$ & 65 & [207] \\
\hline $\mathrm{F}_{5}$ & $\mathrm{SCu}$ & $\mathrm{C}_{8} \mathrm{~F}_{17}$ & & $\mathrm{DMAC}, 70^{\circ} \mathrm{C}, 20 \mathrm{~h}$ & 0 & [207] \\
\hline $\mathrm{H}$ & $\mathrm{SeNa}$ & $\mathrm{CF}_{3} \mathrm{Br}$ & & $\mathrm{EtOH}, 20^{\circ} \mathrm{C}, 2 \mathrm{~h}$, olefins & $2-60$ & [160] \\
\hline $\mathrm{H}$ & $\mathrm{SeNa}$ & $\mathrm{C}_{4} \mathrm{~F}_{9} \mathrm{l}-\mathrm{C}_{8} \mathrm{~F}_{17} \mathrm{I}$ & & $\mathrm{EtOH}, 20^{\circ} \mathrm{C}, 2 \mathrm{~h}$, olefins & & [160] \\
\hline \multicolumn{7}{|c|}{ Heterocyclic thiols } \\
\hline \multicolumn{2}{|c|}{ Heterocycle } & $\mathrm{R}_{\mathrm{F}}$ & Base & Reaction conditions & Yields & Ref. \\
\hline \multirow{3}{*}{\multicolumn{2}{|c|}{ 2-SH-benzothiazole }} & $\mathrm{C}_{3} \mathrm{~F}_{7}$ & $\mathrm{NEt}_{3}$ & DMF, $55-60{ }^{\circ} \mathrm{C}, 3-48 \mathrm{~h}$ & Traces & [189] \\
\hline & & $\mathrm{C}_{3} \mathrm{~F}_{7}$ & $\mathrm{NEt}_{3}$ & DMF, $20-22{ }^{\circ} \mathrm{C}, 120 \mathrm{~h}$ & 59 & [189] \\
\hline & & $\mathrm{Cl}\left(\mathrm{CF}_{2}\right)_{4-6}$ & $\mathrm{NaH}$ & $\mathrm{DMF}, 70^{\circ} \mathrm{C}, 10 \mathrm{~h}$ & $0-4.5^{\mathrm{c}}$ & [169] \\
\hline \multicolumn{2}{|c|}{ 2-SH-benzimidazole } & $\mathrm{Cl}\left(\mathrm{CF}_{2}\right)_{4-6}$ & $\mathrm{NaH}$ & $\mathrm{DMF}, 70^{\circ} \mathrm{C}, 10 \mathrm{~h}$ & $0-3^{d}$ & [169] \\
\hline \multicolumn{2}{|c|}{ 8-SNa-quinoline } & $\mathrm{C}_{3} \mathrm{~F}_{7}$ & $\mathrm{NEt}_{3}$ & DMF, $20-22^{\circ} \mathrm{C}, 24 \mathrm{~h}$ & 72 & [189] \\
\hline \multicolumn{7}{|c|}{$\begin{array}{l}\text { aln the presence of norbornene and styrene the yields are } 30 \% \text { and } 0 \% \text {, respectively. } \\
b_{\alpha, \omega} \text {-Bis(SAr)perfluoroalkanes. } \\
{ }^{8} 8.5 \% \text { conver. } R_{F} l . \\
d_{\sim 3 \%} \text { conver. } R_{F} l .\end{array}$} \\
\hline
\end{tabular}

inhibits the reaction. The addition of olefins such as norbornene or styrene [188] has a similar effect and perfluoroalkyl derivatives of these olefins have been identified in the reaction products. The formation of radicals in the reaction of PhSeNa with perfluoroalkyl halides $\left(\mathrm{PhSe}^{\bullet}\right.$ and $\left.\mathrm{R}_{\mathrm{F}}{ }^{\circ}\right)$ has been firmly established from their interception by unsaturated compounds [160].

Further confirmation of a radical mechanism was obtained by studying the reaction without an initiator (Table 12 and Table 13). The decrease of reaction temperature, carrying out the reaction in the absence of light, the presence of electronwithdrawing substituents in the thiol ring and use of low-polar solvents all led to lower $\operatorname{ArSR}_{\mathrm{F}}$ yields. Also replacement of
$\mathrm{C}_{3} \mathrm{~F}_{7} \mathrm{I}$ for $\mathrm{CF}_{3} \mathrm{I}$ leads to a slower reaction and reduced yields of aryl perfluoroalkyl sulfides. In spite of heptafluoropropyl iodide being a stronger oxidant than $\mathrm{CF}_{3} \mathrm{I}[182,209]$, greater amounts of diaryl disulfides are obtained only with $\mathrm{CF}_{3} \mathrm{I}$. The factors listed above influence the yields of diaryl disulfides in a different way. They either do not change (in darkness), or they even slightly increase (from 3-4 to $12-13 \%$ ).

These observations point towards the rate determining step of the reaction [189]. Two steps (Scheme 51), i.e., the rapid fragmentation of the radical anion $\mathrm{R}_{\mathrm{F}} \mathrm{X}^{-\bullet}$ (Equation 2) [173] and recombination of the electrophilic radical $\mathrm{R}_{\mathrm{F}}{ }^{\cdot}$ with the $\mathrm{ArS}^{-}$ anion (Equation 3) are fast and cannot therefore be rate limiting. 
Table 12: Reaction conditions of thiophenoxides $\mathrm{RC}_{6} \mathrm{H}_{4} \mathrm{~S}^{-} \mathrm{Et}_{3} \mathrm{NH}^{+}$with $\mathrm{R}_{\mathrm{F}}$ l without irradiation [189].

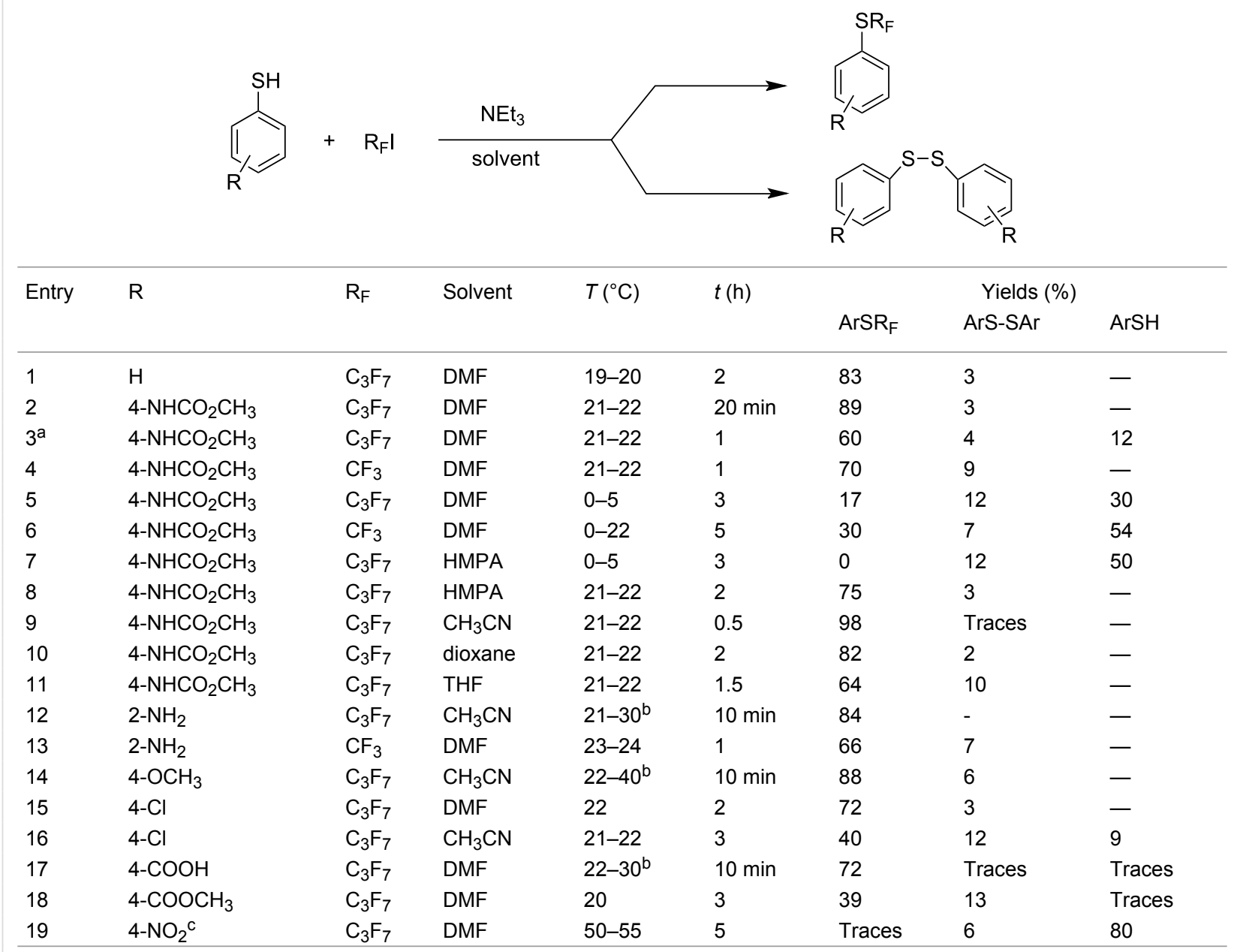

an the dark.

bSpontaneous warming.

cSodium thiophenoxide.

Since all experimental factors (light, temperature, solvent etc.) have an inverted influence on the yields of disulfides, it can be assumed that Equation 1, the generation of $\mathrm{ArS}^{\bullet}$ is also not limiting. Therefore electron transfer from the radical anion $\left[\mathrm{ArSR}_{\mathrm{F}}\right]^{-\bullet}$, Equation 4, seems to be the most likely.

Homogeneous catalysis by the methyl viologen (MV) [186] supports this. This catalyst can oxidize the radical anion $\left[\mathrm{ArSR}_{\mathrm{F}}\right]^{-\bullet}$ via its dication $\left(\mathrm{MV}^{2+}\right)[200,202]$, accelerating the last step (Scheme 52).

\subsection{Radical perfluoroalkylation}

Synthetic methods for aryl perfluoroalkyl sulfides via $\mathrm{R}_{\mathrm{F}}{ }^{\circ}$ radicals are now described. Prolonged UV irradiation of $\mathrm{CF}_{3} \mathrm{I}$ solutions with diaryl disulfides in liquid ammonia results in the formation of the corresponding aryl trifluoromethyl sulfides (Table 13).

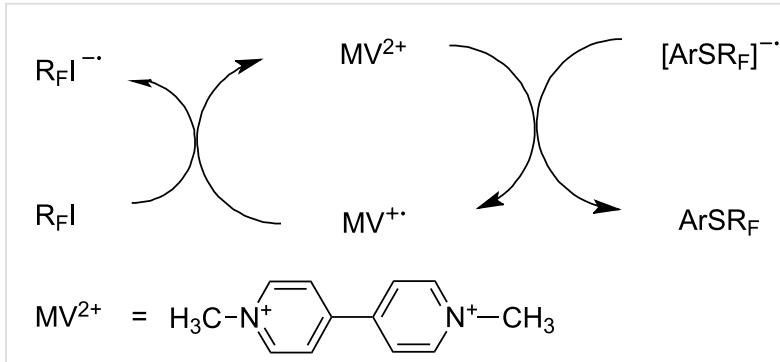

Scheme 52: A double role of $M V$ in the catalysis of $R_{F} I$ reactions with aryl thiols.

For diaryl disulfides the $\mathrm{CF}_{3}{ }^{\bullet}$ radical can attack either the sulfur atom or the aromatic ring, [132,210] and thus give rise to undesired side products. Arylperfluoroalkyl sulfides are formed also in a reverse strategy from aliphatic disulfides and aryl radicals. For example, during irradiation of bis(trifluoromethyl) disul- 
Table 13: UV irradiation of $\mathrm{CF}_{3} \mathrm{l}$ with diaryl disulfides in a sealed quartz tube [157]

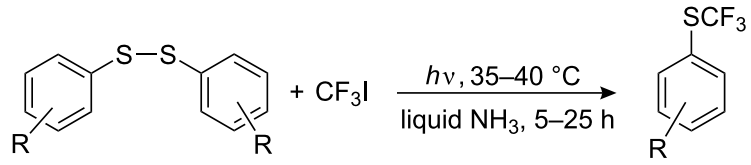

\begin{tabular}{lll}
\hline $\mathrm{R}$ & $t(\mathrm{~h})$ & Yield of $\operatorname{ArSCF}_{3}(\%)$ \\
\hline $\mathrm{H}$ & & $12^{\mathrm{a}}$ \\
$4-\mathrm{Cl}$ & 5 & $36.5^{\mathrm{a}}$ \\
$4-\mathrm{NO}_{2}$ & 25 & 58 \\
$2-\mathrm{NO}_{2}$ & 12 & 72 \\
\hline
\end{tabular}

${ }^{a}$ Extracted from mixtures.

fide and pentafluoroiodobenzene [211] the product mixture contains $\mathrm{C}_{6} \mathrm{~F}_{5} \mathrm{SCF}_{3}, \mathrm{C}_{6} \mathrm{~F}_{5} \mathrm{SSCF}_{3}, \mathrm{CF}_{3} \mathrm{I}$ as well as $\left(\mathrm{CF}_{3} \mathrm{~S}\right)_{2}$ with $\left(\mathrm{CF}_{3}\right)_{2} \mathrm{~S}$ suggesting the following reaction mechanism (Scheme 53).

$N$-Trifluoromethyl- $N$-nitrosobenzene sulfonamide has been used as a source of $\mathrm{CF}_{3}{ }^{\cdot}$ radicals. This reagent (obtained by reaction of $\mathrm{CF}_{3} \mathrm{NO}, \mathrm{NH}_{2} \mathrm{OH}$ and benzenesulfonic acid chloride) reacts with organic disulfides under irradiation or on mild heating to give the corresponding trifluoromethyl sulfides (Scheme 54).
The $N$ - trifluoromethylnitrososulfonamide of trifluoromethane sulfonic acid reacts similarly with aliphatic disulfides [214]. Interaction of $\mathrm{CF}_{3} \mathrm{NO}$ with aryl sulfonamides generates relatively stable trifluoromethyl azosulfonyl arenes $\mathrm{ArSO}_{2} \mathrm{~N}=\mathrm{NCF}_{3}$, which decomposed on heating to $\mathrm{CF}_{3}{ }^{\cdot}$ radicals which react with organic disulfides to form trifluoromethyl sulfides [215] (Scheme 55).

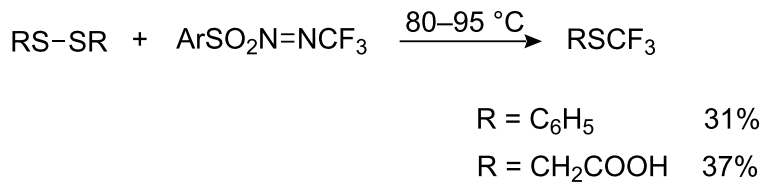

Scheme 55: Radical trifluoromethylation of organic disulfides with $\mathrm{ArSO}_{2} \mathrm{~N}=\mathrm{NCF}_{3}$.

Barton has shown [216] that the irradiation of thiohydroxamic esters of perfluorocarboxylic acids generates $\mathrm{R}_{\mathrm{F}}{ }^{\bullet}$ radicals which in the presence of olefins give addition products. However, in the absence of radical traps they attack the sulfur to yield, for example, $S$-perfluoroalkyl derivatives of pyridine (Scheme 56).

Decarboxylation of non-fluorinated carboxylic acid esters proceeds in a similar manner to afford 2-pyridyl sulfides. However, in the presence of $\mathrm{C}_{6} \mathrm{~F}_{13} \mathrm{I}$ the reaction follows a different course where the perfluorinated radical attacks sulfur with the formation of the fluorinated sulfide [217] (Scheme 57).

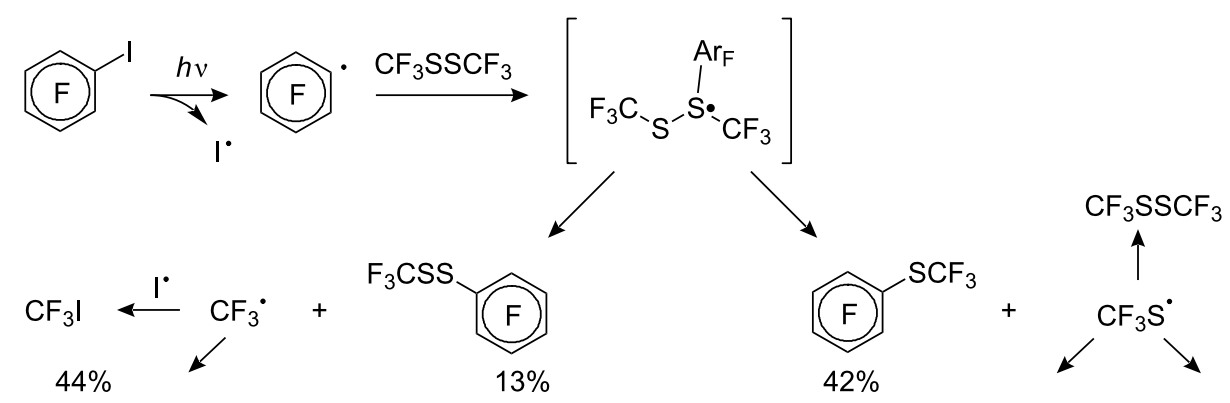

Scheme 53: Photochemical reaction of pentafluoroiodobenzene with trifluoromethyl disulfide.

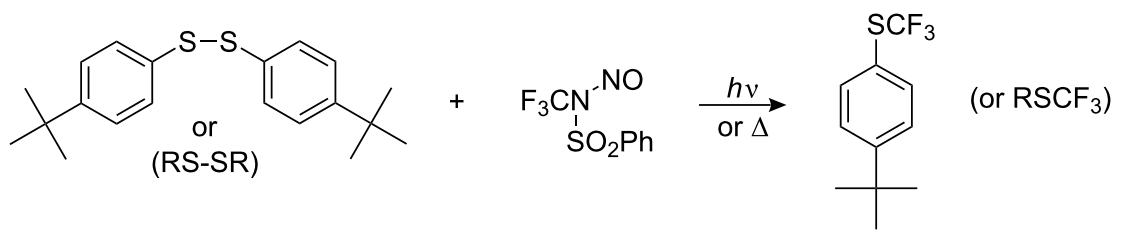

$\mathrm{R}=\mathrm{CH}_{2} \mathrm{COOH}, \mathrm{CH}_{2} \mathrm{COOBu}$, etc. 


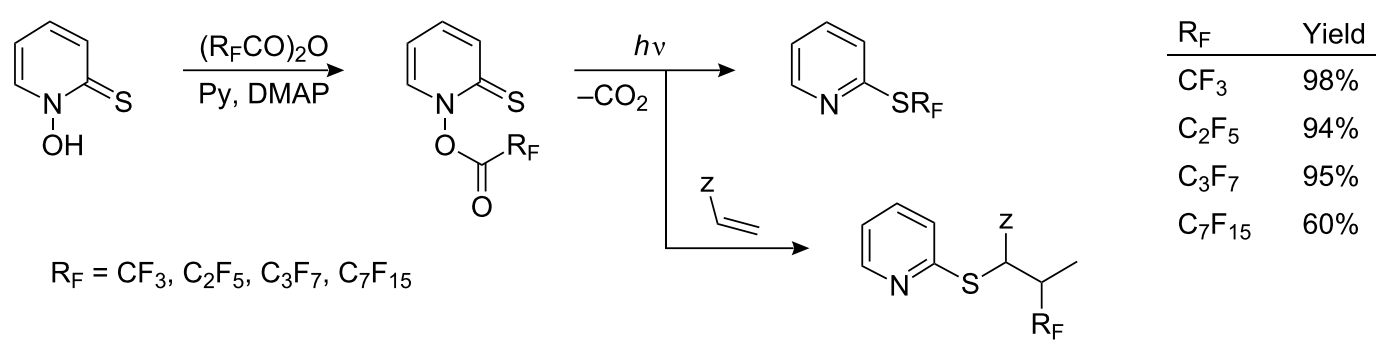

Scheme 56: Barton's S-perfluoroalkylation reactions [216].

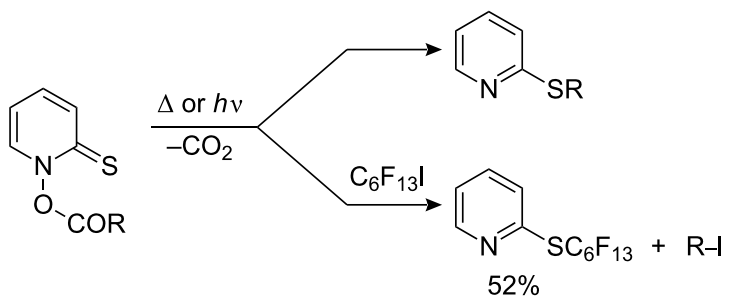

$\mathrm{R}=\mathrm{Ad}, p-\mathrm{MeO}-\mathrm{C}_{6} \mathrm{H}_{4}, p-\mathrm{NO}_{2}-\mathrm{C}_{6} \mathrm{H}_{4}$, 1-naphthyl

Scheme 57: Decarboxylation of thiohydroxamic esters in the presence of $\mathrm{C}_{6} \mathrm{~F}_{13} \mathrm{I}$.

The irradiation of thioesters of trifluoroacetic and trifluoromethanesulfonic acids in refluxing methylene chloride results in their decarbonylation (or desulfonation in the case of $\mathrm{CF}_{3} \mathrm{SO}_{2} \mathrm{SR}$ ) with the production of $\mathrm{CF}_{3} \cdot$ radicals, which then react with diaryl- or dialkyl disulfides (Scheme 58).

The formation of aryl trifluoromethyl sulfides from thioesters of trifluoroacetic acid occurs in rather better yields (30-40\%) than from the corresponding esters of trifluoromethanesulfonic acid (20-30\%). Alkyl thioesters of trifluoroacetic and trifluoromethanesulfonic acids form $\mathrm{AlkSCF}_{3}$ in higher yields (up to
$80 \%$ ). As shown in Scheme 58, the $\mathrm{CF}_{3}{ }^{\circ}$ radical can attack at several sites. Phenyl selenide esters of trifluoromethanesulfonic acid react analogously [218].

The photochemical decomposition of trifluoromethanesulfonic and carboxylic thioesters affords $\mathrm{CF}_{3}{ }^{\bullet}$ radicals which can be used to prepare trifluoromethyl sulfides [219].

Xenon difluoride has been used to initiate oxidative decarboxylation of perfluorocarboxylic acids for $\mathrm{R}_{\mathrm{F}}{ }^{\cdot}$ generation and with aromatic and heterocyclic compounds the perfluoroalkyl groups can also become incorporated into the aromatic ring [220]. Nevertheless, Sipyagin et al, have employed this method for the perfluoroalkylation of thiols such as polychloropyridine thiols [221]. Two different methods were used: the action of preformed xenon carboxylates (method A) or treatment of a pyridinethiol solution in $\mathrm{R}_{\mathrm{F}} \mathrm{COOH}$ directly with xenon difluoride (method $\mathrm{B}$ ). A range of isomeric perfluoroalkyl sulfides was obtained (Scheme 59).

Similar reactions have been carried out with tetrafluoropyridine 4-thiol [224] and its corresponding disulfide [225,226] (40-50\% yield). The formation of $S$-perfluoroalkyl derivatives with performed xenon carboxylates from nitro aromatic disulfides was also successful (Scheme 60).<smiles></smiles> 


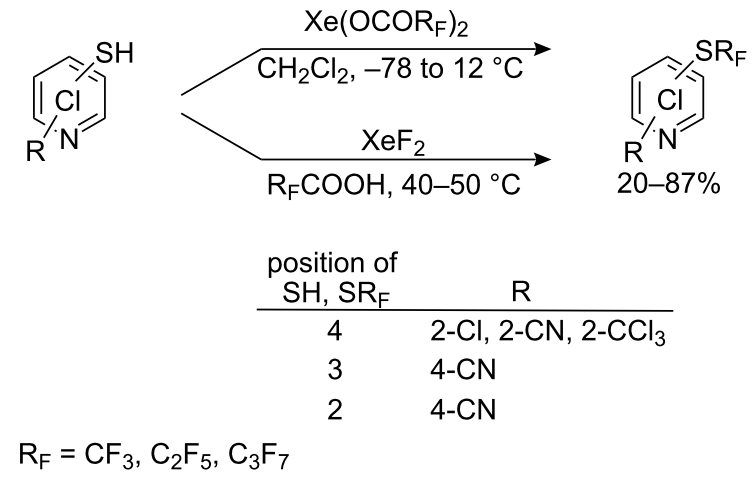

Scheme 59: Perfluoroalkylation of polychloropyridine thiols with xenon perfluorocarboxylates or $\mathrm{XeF}_{2}[222,223]$.

Perfluoroalkylsulfinic acids can also be used for oxidative decomposition. For example, careful treatment of sodium trifluoromethylsulfinate with tert-butyl hydroperoxide in the presence of an organic disulfide gives the corresponding trifluoromethyl sulfide [228,229]. Aliphatic disulfides react well to give $\mathrm{AlkSCF}_{3}$ but problems arise with aromatic disulfides due to attack of the $\mathrm{CF}_{3}{ }^{\cdot}$ radical on the aromatic rings. For example, diphenyl disulfide is converted only in $13 \%$ yield. The $\mathrm{S} / \mathrm{C}$ ratio reflecting the amount of trifluoromethylation on sulfur and on the aryl ring depends on the solvent. In $\mathrm{CH}_{3} \mathrm{CN}$ it is $36: 64$, while in aqueous $\mathrm{CH}_{3} \mathrm{CN}$ it is 60:40. Dichlorodiphenyl disulfide gives the best ratio in favor of the sulfide in aqueous acetonitrile [228].

One final method of $\mathrm{CF}_{3}{ }^{\cdot}$ radical generation involves the interaction of $\mathrm{Bi}\left(\mathrm{CF}_{3}\right)_{3} / \mathrm{Cu}\left(\mathrm{OCOCH}_{3}\right)_{2}$ with thiophenolate (Scheme 61)

$$
\mathrm{PhS}^{-+} \mathrm{NBu}_{4} \stackrel{\mathrm{Bi}\left(\mathrm{CF}_{3}\right)_{3} / \mathrm{CuAc}_{2}}{\longrightarrow} \mathrm{PhSCF}_{3}+\mathrm{PhSSPh}
$$

Scheme 61: $\mathrm{Bi}\left(\mathrm{CF}_{3}\right)_{3} / \mathrm{Cu}\left(\mathrm{OCOCH}_{3}\right)_{2}$ trifluoromethylation of thiophenolate [230].
The above methods for the synthesis of aryl perfluoroalkyl sulfides all generate electrophilic $\mathrm{R}_{\mathrm{F}}{ }^{\circ}$ radicals which prefers to react at nucleophilic reaction centers such as $\mathrm{S}^{-}, \mathrm{C}=\mathrm{S}$ or $\mathrm{S}^{*}$. In the case of diaryl disulfides [228] the regioselectivity of attack is less controlled due to ring delocalization.

\subsection{Anionic perfluoroalkylation}

This method of perfluoroalkylation involves the reaction of aromatic or heterocyclic sulfur compounds with perfluoroalkyl anions, stabilized by suitable ligands, or with a reagent that generates such an anion.

Perfluoroalkyl anions are extremely unstable. For example, the $\mathrm{CF}_{3}$ anion decomposes at $-100{ }^{\circ} \mathrm{C}$ with the elimination of $\mathrm{F}^{-}$ and formation of difluorocarbene, which reacts further or dimerizes [123]. Nevertheless, in the last two decades nucleophilic perfluoroalkylation of organic compounds has expanded. The problem of $\mathrm{R}_{\mathrm{F}}$-lithium anion stability in synthesis has been reviewed [24]. Trifluoromethylated reagents of heavy metals and their application in organic synthesis were considered by Barton [25], whilst perfluoroalkylated [31,32] and trifluoromethylated $[27,28,30]$ organosilicon compounds have attracted considerable interest. However, despite the large body of literature involving the use of such reagents, the synthesis of aryl perfluoroalkyl sulfides is restricted to anionic attack on sulfenyl chlorides and thiocyanates.

Various methods for the synthesis of aryl perfluoroalkyl sulfides, depending on the mode of generation of the perfluoroalkyl anion, are described below.

\subsection{1. " $R_{F}{ }^{-}$" from a perfluorinated olefins}

Relatively stable tertiary perfluoroalkyl carbanions can be prepared by addition of fluoride ion to fluoroolefins [151,231234] or by the deprotonation of monohydroperfluoroalkanes or their derivatives [235,236] as shown in Scheme 62. Most processes involve generating the hexafluoroisopropyl carbanions with a third stabilizing group such as $\mathrm{CF}_{3}$ [151,231,232,236], $\mathrm{C}_{3} \mathrm{~F}_{7}$ [233,234], as well as $\mathrm{CN}, \mathrm{COC}_{2} \mathrm{~F}_{5}$, COOMe $[232,236]$. Reactions of the resulting salts with aryl<smiles>O=[N+]([O-])c1cc(SSc2cc([N+](=O)[O-])c(Cl)c([N+](=O)[O-])c2)cc([N+](=O)[O-])c1Cl</smiles>

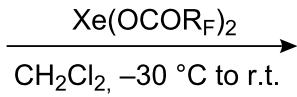<smiles>O=[N+]([O-])c1cc([Se]F)cc([N+](=O)[O-])c1Cl</smiles>

\begin{tabular}{ll}
$\mathrm{R}_{\mathrm{F}}$ & Yield \\
\hline $\mathrm{CF}_{3}$ & $70 \%$ \\
$\mathrm{C}_{2} \mathrm{~F}_{5}$ & $66 \%$
\end{tabular}




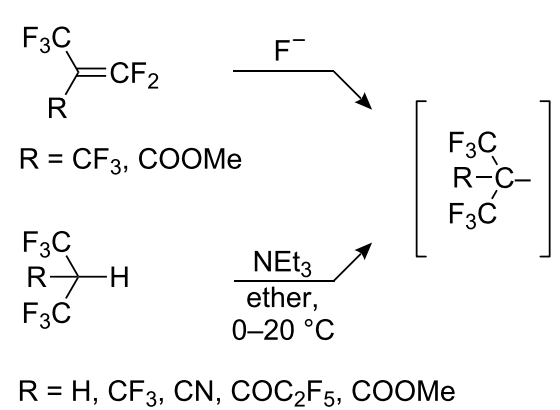

$\mathrm{R}=\mathrm{H}, \mathrm{CF}_{3}, \mathrm{CN}, \mathrm{COC}_{2} \mathrm{~F}_{5}, \mathrm{COOMe}$
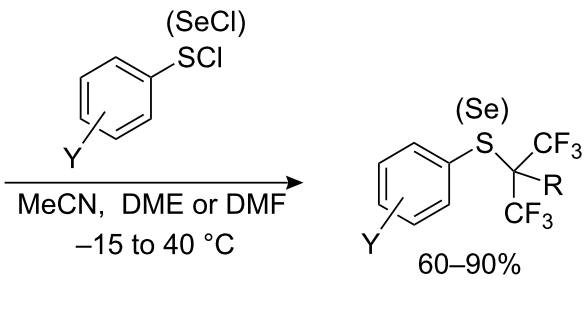

$\mathrm{Y}=\mathrm{H} ; p-\mathrm{CH}_{3} ; p-\mathrm{Cl} ; 2,4,6-$ and $2,3,6-\mathrm{Me}_{3}$;

$\mathrm{Me}_{5} ; o-, m-, p-\mathrm{NO}_{2} ; m-$ and $p$-COOMe

Scheme 62: Reaction of fluorinated carbanions with aryl sulfenyl chlorides.

sulfenyl (or aryl selenyl) chlorides yield perfluoro- or polyfluoroalkyl sulfides (selenides).

The $\left[\mathrm{C}_{3} \mathrm{~F}_{7}\left(\mathrm{CF}_{3}\right)_{2} \mathrm{C}\right]^{-}$anion, obtained from isomeric dimers of perfluoropropylene in the presence of $\mathrm{KF}$ or $\mathrm{CsF}$, reacts with sulfenyl chlorides and selenyl chlorides to afford the corresponding sulfides and selenides bearing a tertiary perfluorohexyl group [233].

In the reaction of $\mathrm{R}_{\mathrm{F}}{ }^{-}$carbanions with sulfenyl chlorides high yields of sulfides are obtained when either electron-withdrawing or electron-donating substituents are present on the aryl ring. The yields of isomeric nitrophenyl perfluoro-tert-butyl sulfides decrease, the closer the nitro group is to the sulfur atom: $p-\mathrm{NO}_{2}-86 \%, m-\mathrm{NO}_{2}-78 \%$ [231] and $o-\mathrm{NO}_{2}-68 \%$ [232]. Both secondary and tertiary anions react [236] but nature of the counter ion is important. Thus, cesium or potassium perfluoro tert-butyl alkyls obtained by the addition of $\mathrm{CsF}$ or $\mathrm{KF}$ to perfluoroisobutene, give high yields of $\mathrm{ArSC}\left(\mathrm{CF}_{3}\right)_{3}$ $[151,231,232]$, while the same anion, generated by deprotonation of nonafluoroisobutane $\left(\mathrm{CF}_{3}\right)_{3} \mathrm{CH}$ with $\mathrm{NEt}_{3}$ gives $\mathrm{PhSC}\left(\mathrm{CF}_{3}\right)_{3}$ in low yield $20 \%$ [236].

In the reaction of methyl perfluoromethacrylate with $\mathrm{PhSCl}$ in the presence of fluoride ion, prolonged stirring gave two sulfides as shown in Scheme 63, illustrating the competition between halides $\left(\mathrm{F}^{-}\right.$and $\left.\mathrm{Cl}^{-}\right)$for fluoroolefin addition [232].

\subsection{2. " $R_{\mathrm{F}}{ }^{-}$" from perfluoroalkyl halogenides}

In a similar manner to alkylhalides, perfluorinated alkylhalides also form organometallic derivatives which can be used for the synthesis of perfluoroalkyl sulfides. The effectiveness of such reagents depends largely on the counterion which is illustrated below for reactions with organic thiocyanates (Scheme 64). Potassium perfluoroisopropyl (generated from $\mathrm{CF}_{2}=\mathrm{CFCF}_{3}$ and $\mathrm{KF}$ ) reacts with phenyl- and $p$-nitrophenyl thiocyanates in sulfolane at $100{ }^{\circ} \mathrm{C}$, whilst the Grignard reagent $\left(n-\mathrm{C}_{4} \mathrm{~F}_{9} \mathrm{MgI}\right)$ reacts at subzero temperatures.

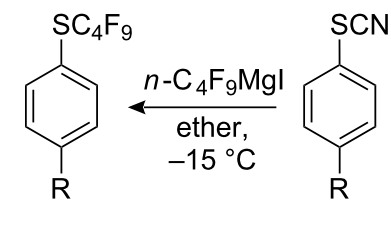<smiles>[R]c1ccc(OC(F)(F)F)cc1</smiles>

$\mathrm{R}=\mathrm{Cl}, 45 \%$

$$
\begin{array}{ll}
\mathrm{R}=\mathrm{H} & 56 \% \\
\mathrm{R}=\mathrm{NO}_{2} & 57 \%
\end{array}
$$

Scheme 64: Reactions of ArSCN with potassium and magnesium perfluorocarbanions [237].

Cuprates react with benzyl thiocyanate but require more forcing conditions, i.e., $100{ }^{\circ} \mathrm{C}$ [237], whereas in situ generated zinc reagents $\mathrm{R}_{\mathrm{F}} \mathrm{ZnX}$ react with thiocyanates at $20^{\circ} \mathrm{C}$ in pyridine [238].

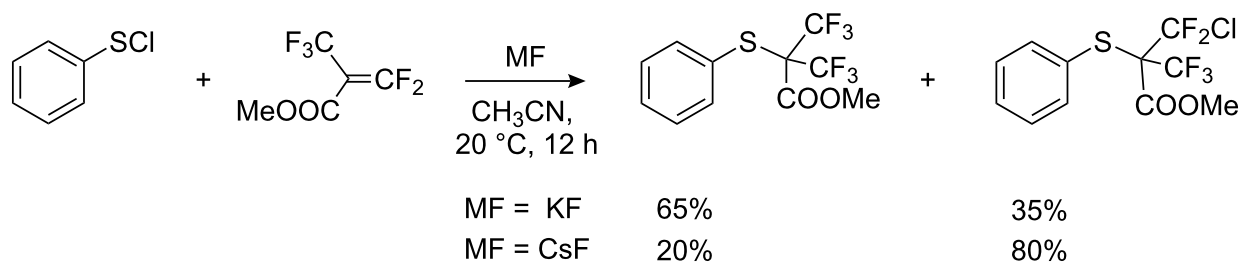


Recently, it has been shown that tetrakis(dimethylamino)ethylene (TDAE) can undergo a two-electron transfer to perfluoroalkyliodides to generate $\mathrm{R}_{\mathrm{F}}{ }^{-}$anions [187] which react with organic disulfides to afford perfluoroalkyl sulfides in high yields $[239,240]$. The economy of this method, as distinct from previous methods [196,241-248], lies in the fact that the thiolate released by the first nucleophilic attack on the disulfide reacts directly with a second equivalent of perfluoroalkyliodide, to form a second equivalent of the desired perfluoroalkyl sulfide (Scheme 65). This approach thus combines two principles of trifluoromethylation, i.e., nucleophilic attack of the $\mathrm{R}_{\mathrm{F}}$-anion on the disulfide and reaction of a radical anion with a thiol as noted in section 4.1 .

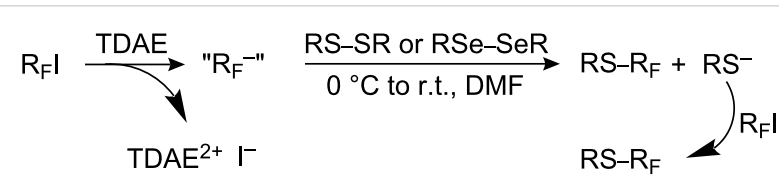

$$
\begin{aligned}
& \begin{array}{lll}
\mathrm{R}_{\mathrm{F}}=\mathrm{CF}_{3}, \mathrm{C}_{2} \mathrm{~F}_{5}, \mathrm{C}_{4} \mathrm{~F}_{9} \quad \mathrm{R} & \text { Yields of } \mathrm{RSR}_{\mathrm{F}} \\
\cline { 2 - 3 } & \mathrm{Ph} & 93 \%\left(99 \% \mathrm{PhSeCF}_{3}\right)
\end{array} \\
& \text { 4-Py 95-100\% } \\
& \text { 2-Py } 90 \% \\
& n \text {-Bu } \quad 88 \%
\end{aligned}
$$

Scheme 65: Reactions of $R_{F} I$ with TDAE and organic disulfides $[239,240]$.

\subsection{3. " $R_{F}{ }^{-}$" from perfluorocarboxylic acids}

A simple method for the generation of metal derivatives of perfluoroalkyl carbanions by the decarboxylation of alkali salts of perfluorocarboxylic acids, has also been used. For example, heating potassium perfluoroalkyl carboxylates in the presence of diaryl disulfides in DMF or sulfolane leads to the formation of the corresponding aryl perfluoroalkyl sulfides as summarized in Table 14.

Disulfides of pyridine [242], pyrimidine and naphthalene [249] have also been used in such reactions. The use of this method for longer perfluorocarboxylic acids leads to product mixtures that result from chain isomerism and cyclisation [250,251] (Scheme 66).
Table 14: Perfluoroalkylation of aryl disulfides by decarboxylation of perfluorocarboxylates.

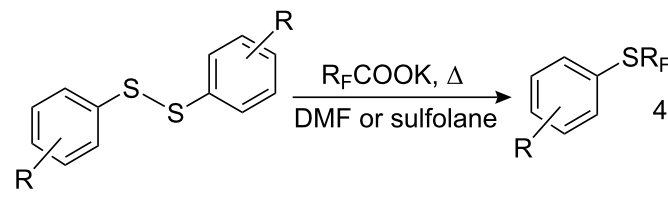
$40-82 \%$

\begin{tabular}{llllll}
\hline $\mathrm{R}$ & $\mathrm{R}_{\mathrm{F}}$ & Solvent & $T\left({ }^{\circ} \mathrm{C}\right)$ & $\begin{array}{l}\text { Yield of } \\
\text { ArSR }\end{array}$ & Ref. \\
\hline $\mathrm{H}$ & $\mathrm{CF}_{3}$ & DMF & 140 & 84 & {$[245]$} \\
$\mathrm{H}$ & $\mathrm{CF}_{3}$ & sulfolane & $180-230$ & 56 & {$[242]$} \\
$4-\mathrm{Me}$ & $\mathrm{CF}_{3}$ & sulfolane & $180-230$ & 51 & {$[242]$} \\
$4-\mathrm{Cl}$ & $\mathrm{CF}_{3}$ & sulfolane & $180-230$ & 56 & {$[242]$} \\
$4-\mathrm{F}$ & $\mathrm{CF}_{3}$ & sulfolane & $180-230$ & 82 & {$[242]$} \\
$2-\mathrm{Br}$ & $\mathrm{CF}_{3}$ & sulfolane & $180-230$ & 48 & {$[242]$} \\
$4-\mathrm{OMe}$ & $\mathrm{CF}_{3}$ & sulfolane & $180-230$ & 50 & {$[242]$} \\
$\mathrm{H}$ & $\mathrm{C}_{2} \mathrm{~F}_{5}$ & DMF & 145 & 70 & {$[245]$} \\
$4-\mathrm{Me}$ & $\mathrm{C}_{2} \mathrm{~F}_{5}$ & DMF & 145 & 50 & {$[245]$} \\
$4-\mathrm{NO}_{2}$ & $\mathrm{C}_{2} \mathrm{~F}_{5}$ & DMF & 145 & 42 & {$[245]$} \\
& & & & &
\end{tabular}

Polyhalogenated carboxylic acids containing fluorine together with other halogens can also alkylate disulfides. However, the results strongly depend on the structure of halogenated alkyl group. The method is successful for potassium trichloroacetate but not for difluorochloroacetate. In the latter case the corresponding sulfide $\mathrm{PhSCF}_{2} \mathrm{Cl}$ was found but only in trace amounts whilst $\mathrm{PhSCCl}_{3}$ is obtained in $80 \%$ yield [245]. The mixed haloalkyl anions appear to be less stable.

The stability and reactivity of perfluoroalkyl anions largely depend on the solvents used. For example, $\mathrm{CF}_{3} \mathrm{MgI}$ [252-254] and $\mathrm{CF}_{3} \mathrm{Li}[123,255-258]$ in diethyl ether are unstable even at low temperatures, but in coordinating solvents such as sulfolane, $\mathrm{N}$-methylpyrrolidone, HMPA and especially, in DMF, the $\mathrm{CF}_{3}{ }^{-}$anion does not decompose so readily and can be used as a nucleophilic reagent [259].

\subsection{4. " $\mathrm{CF}_{3}{ }^{-}$" from trifluoromethane (fluoroform)}

Trifluoromethane (fluoroform) has been used as a source of the trifluoromethyl anion. Trifluoromethane is a waste product of

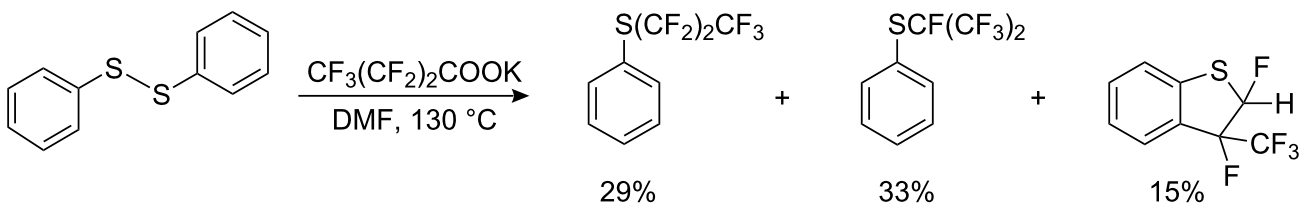


Teflon manufacture and it is of interest as a raw material for organofluorine chemistry [260]. However, its application has been restricted by the low stability of the $\mathrm{CF}_{3}{ }^{-}$anion [123,252255].

The $\mathrm{CF}_{3}{ }^{-}$anion has greater stability when the counter ion is a bulky ammonium ion, and in the presence of pyrrolidone it reacts with aldehydes and ketones [261]. This suggests that an intermediate gem-aminoalcoholate is involved. The method is improved with DMF, which is also thought to form a stable aminoalcoholate intermediate (Scheme 67) [243,262,263].

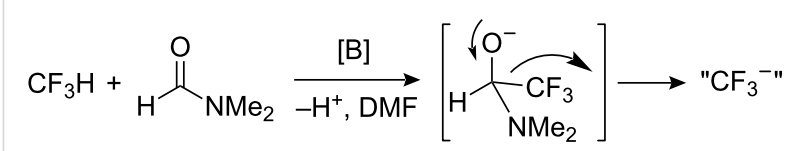

Scheme 67: Organization of a stable form of " $\mathrm{CF}_{3}{ }^{- \text {" }}$ anion in the DMF.

This mechanism is supported by the observation that equivalent reactions do not occur in THF or DMSO [263]. Furthermore, the intermediate $\mathrm{CF}_{3}$ aminoalcoholate has been trapped in its protonated form and as hydrated trifluoroacetaldehyde by the action of acids, as well as trapped as a silyl ether [243]. The deprotonation of fluoroform has been applied successfully for the synthesis of aromatic trifluoromethyl sulfides and selenides, as summarized in Table 15.

Langlois et al. have used silylated amines in the presence of fluoride ion to promote fluoroform deprotonation [244]. For example, with $\left(\mathrm{Me}_{3} \mathrm{Si}\right)_{3} \mathrm{~N}$ such reactions were possible in both DMF and THF. In the latter case stabilization of the $\mathrm{CF}_{3}{ }^{-}$anion and its reaction with disulfide probably involves a transition state complex such as that depicted in Scheme 68.

In the case of trifluoromethylation of aliphatic disulfides, silazanes are the preferred reagents. However, in the case of diaryl disulfides, e.g., diphenyl disulfide, the significant formation of byproducts occurs and, $\mathrm{PhSN}(\mathrm{TMS})_{2}$ (46\%) and $\mathrm{PhSCHF}_{2}(23 \%)$ are main reaction products. Other $\mathrm{CF}_{3}$ aminomethanols have been synthesized by Langlois et al. [264] (Figure 7).
Table 15: Reaction of the $\mathrm{CF}_{3}{ }^{-}$anion derived from fluoroform with S-derivatives of thiophenols.

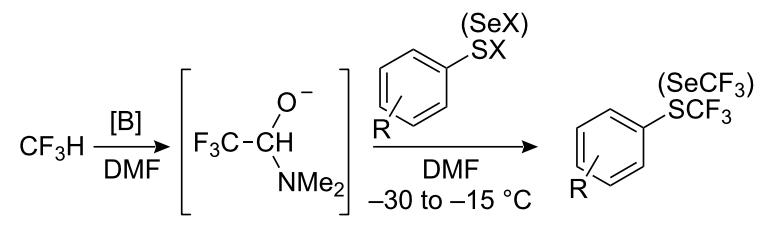

\begin{tabular}{lllll}
\hline $\mathrm{B}$ & $\mathrm{R}$ & $\mathrm{X}$ & Yield, \% & Ref. \\
\hline$t$-BuOK & $\mathrm{H}$ & $\mathrm{SPh}$ & 80 & {$[243]$} \\
$t$-BuOK & $\mathrm{H}$ & $\mathrm{SO}_{2} \mathrm{Ph}$ & 90 & {$[243]$} \\
$t$-BuOK & $4-\mathrm{NO}_{2}$ & $\mathrm{Cl}$ & 60 & {$[243]$} \\
$\mathrm{LiN}(\mathrm{TMS})_{2} / \mathrm{NH}(\mathrm{TMS})_{2}$ & $\mathrm{H}$ & $\mathrm{SPh}$ & 4 & {$[244]$} \\
$\mathrm{N}(\mathrm{TMS})_{3} / \mathrm{Me}_{4} \mathrm{NF}$ & $\mathrm{H}$ & $\mathrm{SPh}$ & 6 & {$[244]$} \\
$t$-BuOK & $\mathrm{H}$ & $\mathrm{SPh}$ & 82 & {$[244]$} \\
$\mathrm{N}(\mathrm{TMS})_{3} / \mathrm{Me}_{4} \mathrm{NF}$ & $\mathrm{H}$ & $\mathrm{SePh}$ & $61^{\mathrm{a}}$ & {$[244]$} \\
$t$-BuOK & $\mathrm{H}$ & $\mathrm{SePh}$ & $77^{\mathrm{a}}$ & {$[244]$} \\
\hline
\end{tabular}

${ }^{\text {aphSeCF}} 3$.

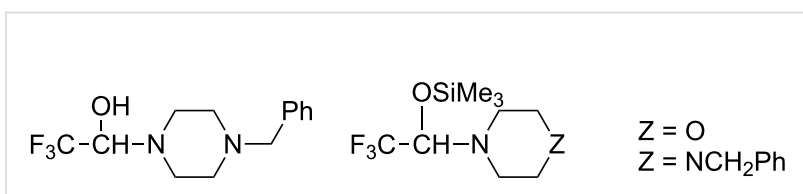

Figure 7: Other examples of aminomethanols [264].

Trifluoromethylation of disulfides by the first of them was efficient, for example, $87 \%$ in the case of $\mathrm{PhSCF}_{3}$ but less efficient for diselenides $\left(\mathrm{PhSeCF}_{3} 45 \%\right)$ [246]. The reaction failed with bis(4-chlorophenyl) disulfide and dioctyl disulfide where only by-products were generated.

Silylated hemiaminals are more suitable for $\mathrm{CF}_{3}{ }^{-}$transfer (Table 16), although high reaction temperatures $\left(60-80^{\circ} \mathrm{C}\right)$ are required.

The use of $\mathrm{F}^{-}$anion as an alkaline agent (De-Shopge reagent, $\left.\mathrm{Bu}_{4} \mathrm{~N}^{+} \mathrm{Ph}_{3} \mathrm{SiF}_{2}^{-}\right)$in place of a strong base $(t$-BuOK) allows trifluoromethylation of aliphatic disulfides.

$$
\mathrm{CHF}_{3}+\mathrm{RS}-\mathrm{SR}+\left(\mathrm{Me}_{3} \mathrm{Si}\right)_{3} \mathrm{~N} \underset{\mathrm{THF}}{\mathrm{MF}}\left[\mathrm{Me}_{3} \mathrm{Si}^{-}\right.
$$


Table 16: Reactions of silylated hemiaminals with disulfides [246].

\begin{tabular}{llllll} 
& & & \\
\hline $\mathrm{R}$ & $\mathrm{S}(\mathrm{Se})$ & $\mathrm{Z}$ & ${ }^{\circ} \mathrm{C}$ & $\mathrm{Yield}, \%$ \\
$\mathrm{H}$ & $\mathrm{S}$ & $\mathrm{O}$ & $\mathrm{CsF}$ & 80 & 50 \\
$\mathrm{H}$ & $\mathrm{S}$ & $\mathrm{O}$ & $\mathrm{TBAT}$ & 80 & 90 \\
$\mathrm{H}$ & $\mathrm{S}$ & $\mathrm{NCH}{ }_{2} \mathrm{Ph}$ TBAT & 60 & 78 \\
$\mathrm{H}$ & $\mathrm{S}$ & $\mathrm{NCH}_{2} \mathrm{Ph}$ TBAT & 80 & 95 \\
$4-\mathrm{Cl}$ & $\mathrm{S}$ & $\mathrm{NCH}_{2} \mathrm{Ph}$ TBAT & 80 & 95 \\
$\mathrm{H}$ & $\mathrm{Se}$ & $\mathrm{NCH}_{2} \mathrm{Ph}$ TBAT & 80 & 92 \\
$4-\mathrm{Cl}$ & $\mathrm{Se}$ & $\mathrm{NCH}_{2} \mathrm{Ph}$ TBAT & 80 & 75 \\
\hline
\end{tabular}

атвAT: $\mathrm{Bu}_{4} \mathrm{~N}^{+} \mathrm{Ph}_{3} \mathrm{SiF}_{2}^{-}$.

\subsection{5. " $\mathrm{CF}_{3}{ }^{-}$" anion from trifluoromethyl silanes}

Perfluoroalkyltrialkyl silanes in the presence of fluoride ion generate reactive $\mathrm{R}_{\mathrm{F}}$ carbanions which have been used widely in synthesis [27,28,30-32,265]. For example, Ruppert's reagent, $\mathrm{CF}_{3} \mathrm{SiMe}_{3}$ [266] and its tin analogue $\left(\mathrm{CF}_{3} \mathrm{SnMe}_{3}\right)$ have been used for the nucleophilic introduction of $\mathrm{CF}_{3}$ group to electrophilic sulfur for the preparation of trifluoromethyl sulfoxides and sulfones [267-269]. Trifluoromethyl trimethylsilane has also been used for the synthesis of aromatic trifluoromethyl sulfides and selenides (Table 17).

Table 17: Trifluoromethylation of sulfur and selenium compounds with Ruppert's reagent.

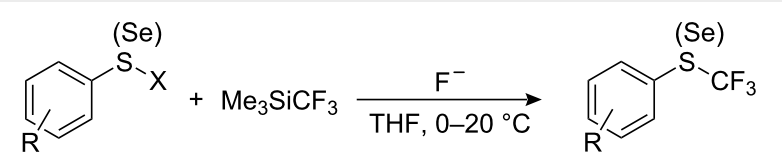

\begin{tabular}{lllll}
\hline $\mathrm{X}$ & $\mathrm{F}^{-}$ & $\mathrm{R}$ & Yield, \% & Ref. \\
\hline $\mathrm{Cl}$ & $\mathrm{TASF}$ & $\mathrm{H}$ & 59 & {$[270]$} \\
$\mathrm{Cl}$ & $\mathrm{TASF}$ & $4-\mathrm{Cl}$ & 72 & {$[270]$} \\
$\mathrm{Cl}$ & $\mathrm{TASF}$ & $4-\mathrm{NO}_{2}$ & 69 & {$[270]$} \\
$\mathrm{Cl}$ & $\mathrm{Bu}_{4} \mathrm{NF}$ & $4-\mathrm{NO}_{2}$ & 14 & {$[241]$} \\
$\mathrm{SPh}$ & $\mathrm{Bu}_{4} \mathrm{NF}$ & $\mathrm{H}$ & $32\left(43^{\mathrm{b}}\right)$ & {$[241]$} \\
$\mathrm{CN}$ & $\mathrm{Bu}_{4} \mathrm{NF}$ & $\mathrm{H}$ & $70\left(58^{\mathrm{b}}\right)$ & {$[271]$} \\
$\mathrm{CN}$ & $\mathrm{Bu}_{4} \mathrm{NF}$ & $4-\mathrm{NO}_{2}$ & 58 & {$[271]$} \\
$\mathrm{CN}$ & $\mathrm{Bu}_{4} \mathrm{NF}$ & $2,4-(\mathrm{OMe})_{2}$ & 30 & {$[271]$} \\
\hline
\end{tabular}

${ }^{\mathrm{a}} \mathrm{TASF}=\left(\mathrm{Me}_{2} \mathrm{~N}\right)_{3} \mathrm{~S}^{+} \mathrm{Me}_{3} \mathrm{SiF}_{2}^{-}$.

${ }^{\mathrm{b}} \mathrm{ArSeCF} \mathrm{S}_{3}$.

Reactions proceed easily in THF or light hydrocarbon solvents and the reaction can also be extended to aliphatic and heterocyclic [271] sulfur-trifluoromethylations. The data (Table 17) indicate that the source of the $\mathrm{F}^{-}$anion exerts an important influence on the reaction of sulfenyl chlorides with $\mathrm{CF}_{3} \mathrm{SiMe}_{3}$ [267]. For example, in the presence of TASF $p$-nitrophenyl trifluoromethyl sulfide is formed in almost $70 \%$ yield, while the use of $\mathrm{Bu}_{4} \mathrm{~N}^{+} \mathrm{F}^{-}$(even 2 equiv) under identical conditions gives only a $14 \%$ yield. In addition, in the reaction of diaryl disulfides with $\mathrm{CF}_{3} \mathrm{SiMe}_{3}$ it has been shown [241] that the best results are obtained when the $\mathrm{Bu}_{4} \mathrm{NF}$ is added with a syringepump rather than by ordinary dropwise addition.

Such trifluoromethylation reactions with $\mathrm{CF}_{3} \mathrm{SiMe}_{3}$ can also be catalysed with cyanide ion. However, this also results in competing side reactions where the cyanide attacks the disulfide directly and is especially problematic in the case of aliphatic disulfides [271].

\subsection{6. " $\mathrm{CF}_{3}$-anion" from $\mathrm{ArSOCF}_{3}$ and $\mathrm{ArSO}_{2} \mathrm{CF}_{3}$}

Aryl trifluoromethyl sulfones react with $\mathrm{CH}_{3} \mathrm{ONa}$ to generate sodium arylsulfonates and fluoroform [272], and with Grignard reagents to generate aryl alkyl- or diaryl sulfones [273]. Also nucleophilic substitution of the pentafluoroethyl group can be induced in bis(pentafluoroethyl) sulfone by various nucleophiles [274]. Prakash et al. have adapted this chemistry for nucleophilic trifluoromethylation. Both phenyl trifluoromethyl sulfone or the corresponding sulfoxide on treatment with $t$-BuOK in DMF generate a $\mathrm{CF}_{3}$-adduct similar to that formed during fluoroform deprotonation [243,263], which is a useful trifluoromethylating agent for aldehydes, ketones and disulfides [248]. An example is shown in Scheme 69.

\begin{tabular}{|c|c|c|}
\hline PhS-SPh & $\underset{\text { DMF },-30{ }^{\circ} \mathrm{C} \text { to r.t. }}{\stackrel{\mathrm{PhSO}_{2} \mathrm{CF}_{3} / t-\mathrm{BuOK}}{\longrightarrow}}$ & $\begin{array}{c}\mathrm{PhSCF}_{3} \\
87 \%\end{array}$ \\
\hline \multicolumn{3}{|c|}{$\begin{array}{l}\text { Scheme 69: Trifluoromethylation of diphenyl disulfide with } \mathrm{PhSO}_{2} \mathrm{CF}_{3} \\
t \text {-BuOK. }\end{array}$} \\
\hline
\end{tabular}

On the other hand, under the same reaction conditions methyl trifluoromethyl sulfone does not function as a trifluoromethylating agent, whilst esters and amides of trifluoromethane sulfinic acid are good trifluoromethyl transfer agents [247] (Scheme 70).

However, trifluoromethylation strategies with aryl trifluoromethyl -sulfoxides, -sulfones, -sulfinates, and amides have to compete with cheaper reagents such as fluoroform, trifluoroacetic acid derivatives and trifluoromethyl halogenides. For the synthesis of aryl trifluoromethyl sulfides, it should be noted that these are prepared from sulfones, which are in turn synthesized from the same sulfides. 


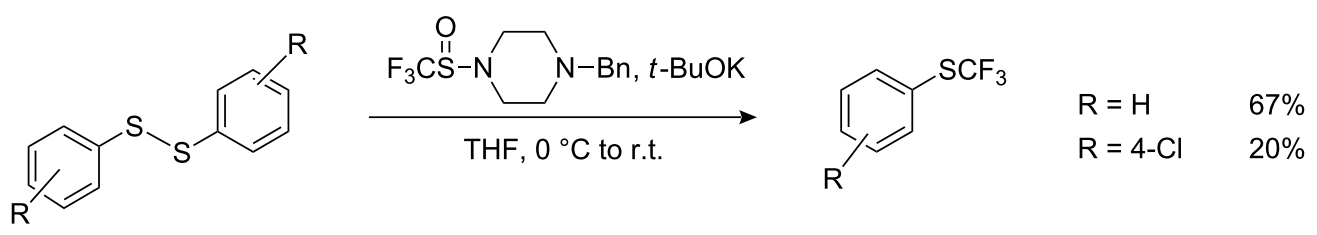

Scheme 70: Amides of trifluoromethane sulfinic acid are sources of $\mathrm{CF}_{3}{ }^{-}$anion.

\subsection{Cationic perfluoroalkylation}

Aryl perfluoroalkyl iodonium reagents as perfluoroalkylating agents were first developed by Yagupolski et al. [275]. Unlike perfluoroalkyl iodides, tolyl perfluoroalkyl iodonium chlorides react easily with sodium thiophenolates and selenophenolates at

Table 18: Interaction of tolyl perfluoroalkyl iodonium chlorides with sodium thiophenolates and selenophenolate [275].

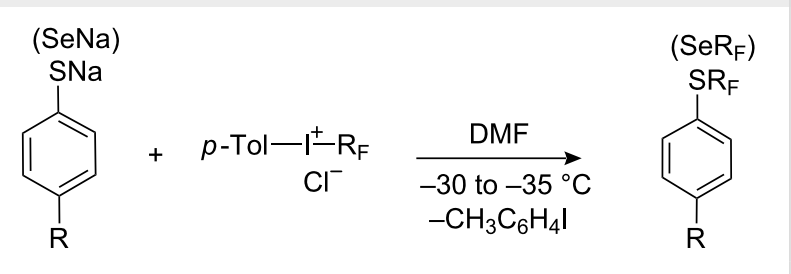

\begin{tabular}{llll}
\hline $\mathrm{R}$ & $\mathrm{R}_{\mathrm{F}}$ & \multicolumn{2}{l}{ Yields, \% (GLC) of } \\
\cline { 3 - 4 } & & $\operatorname{ArSR}_{\mathrm{F}}$ & ArSeOR $_{\mathrm{F}}{ }^{\mathrm{a}}$ \\
\hline $\mathrm{H}$ & $\mathrm{C}_{3} \mathrm{~F}_{7}$ & $61(81)$ & 87 \\
$\mathrm{CH}_{3}$ & $\mathrm{C}_{3} \mathrm{~F}_{7}$ & $71(96)$ & - \\
$\mathrm{NO}_{2}$ & $\mathrm{C}_{3} \mathrm{~F}_{7}$ & $34(56)$ & - \\
$\mathrm{H}$ & $\mathrm{C}_{6} \mathrm{~F}_{13}$ & 41 & 45
\end{tabular}

${ }^{a}$ After chlorination and subsequent hydrolysis of corresponding selenides. low temperature to form the corresponding aryl perfluoroalkyl sulfides and selenides as summarized in Table 18.

These iodonium salts even react with sodium $p$-nitrothiophenolate and while $\mathrm{C}_{3} \mathrm{~F}_{7} \mathrm{I}$ does not react without some initiation [189] the $\mathrm{C}_{3} \mathrm{~F}_{7}$ containing salts (Table 18) react readily. The yields of $p-\mathrm{O}_{2} \mathrm{NC}_{6} \mathrm{H}_{4} \mathrm{SR}_{\mathrm{F}}\left(\mathrm{R}_{\mathrm{F}}=\mathrm{C}_{3} \mathrm{~F}_{7}\right.$ and $\left.\mathrm{C}_{6} \mathrm{~F}_{13}\right)$ are increased to a quantitative level by the use of iodonium tetrafluoroborate salts [276] instead of chlorides.

Similarly, perfluoroalkyl phenyl iodonium trifluoromethanesulfonates (FITS reagents) react with thiolates [277]: Perfluoroalkylation is selective for sulfur even in the presence of other functional groups (e.g. $\mathrm{OH}, \mathrm{NHMe}, \mathrm{COOH}, \mathrm{COOAlk}$ ). The preparation and application of $\mathrm{R}_{\mathrm{F}}$ iodonium salts has been reviewed [33]. However, $\mathrm{CF}_{3}$ iodonium salts were not discussed, presumably due to their low stability.

A "hyper-valent" iodine (III) compound containing a trifluoromethyl group, first synthesized in 2006 [278], appears to be quite stable. This moisture-sensitive reagent reacts with aromatic, heterocyclic and aliphatic thiols at low temperature $\left(-78{ }^{\circ} \mathrm{C}\right)$ with the formation of the corresponding $\mathrm{SCF}_{3}$ derivatives in high yields (Scheme 71).<smiles>O=C(O)c1cccnc1S(F)(F)F</smiles>

$95 \%$

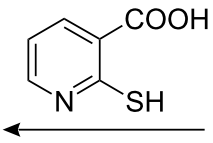<smiles>CC1(C)OI(C(F)(F)F)c2ccccc21</smiles><smiles>Cc1ccc(S)cc1</smiles><smiles>CCCCC</smiles><smiles>Sc1nc2ccccc2o1</smiles><smiles>FC(F)(F)c1nc2ccccc2o1</smiles>

$58 \%$

\begin{tabular}{lr}
\multicolumn{1}{c}{$\mathrm{R}$} & Yield \\
\hline$m-\mathrm{Br}$ & $82 \%$ \\
$p-\mathrm{NO}_{2}$ & $88 \%$ \\
$o-\mathrm{NH}_{2}$ & $82 \%$ \\
$m-\mathrm{NH}_{2}$ & $72 \%$ \\
$p-\mathrm{NHAc}$ & $80 \%$ \\
$o-\mathrm{OH}$ & $91 \%$
\end{tabular}<smiles>[R]c1ccc([Se])cc1</smiles> 
However, this attractive methodology has some drawbacks in that its synthesis involves four steps and trifluoromethylation products must be purified by chromatography to remove a sideproduct - 2-iodophenyl dimethyl carbinol.

Unlike iodonium salts, onium salts of the group VI elements appear to be more stable with $\mathrm{CF}_{3}$ group. Diaryl $\mathrm{R}_{\mathrm{F}}$-sulfonium salts, where $\mathrm{R}_{\mathrm{F}}=\mathrm{CF}_{3}$, are readily synthesized from aryl trifluoromethyl sulfoxides [280]. Reaction of these reagents with sodium $p$-nitrothiophenolate affords the trifluoromethyl sulfide in good yield (Scheme 72).

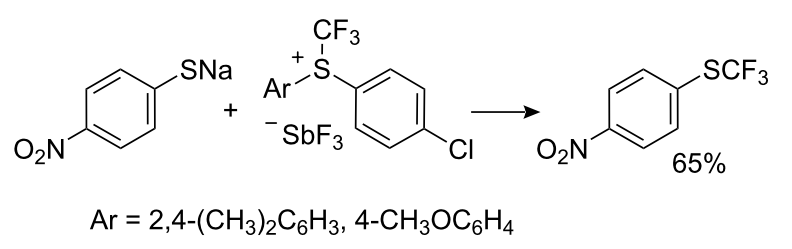

Scheme 72: Trifluoromethylation of $p$-nitrothiophenolate with diaryl $\mathrm{CF}_{3}$ sulfonium salts [280].

It should be noted that for perfluoroalkylation is it necessary to use the diaryl sulfonium salts and not aryl alkyl sulfonium salts, since reaction of $\mathrm{PhS}^{+}\left(\mathrm{CH}_{3}\right) \mathrm{CF}_{3} \mathrm{BF}_{4}^{-}$, with $p$-nitrothiopheno- late yields the $\mathrm{SCH}_{3}$ compound not the $\mathrm{SCF}_{3}$ derivative [280]. Subsequently, diaryl thiophenium, -selenophenium and -tellurophenium reagents have been developed with perfluoroalkyl groups attached to $\mathrm{S}$, Se and Te $[33,281,282]$ which can transfer perfluoroalkyl fragments to nucleophilic centers. In particular, the dibenzo $\left(\mathrm{CF}_{3}\right) \mathrm{S}$-, $\left(\mathrm{CF}_{3}\right) \mathrm{Se}$ - and $\left(\mathrm{CF}_{3}\right) \mathrm{Te}$-phenium systems have been investigated. For example, $\mathrm{S}\left(\mathrm{CF}_{3}\right)$ dibenzothiophenium triflate $(\mathrm{A}=\mathrm{S})$ reacts with sodium thiolate in DMF to give the $S$-trifluoromethyl derivative in high yield. The related selenophenium salt $(\mathrm{A}=\mathrm{Se})$ appears to be more effective in trifluoromethyl transfer (Scheme 73).

The same general reactivity is also observed in reactions of these reagents with aliphatic thiols. Dibenzoselenophenium triflate $\left(\mathrm{A}=\mathrm{Se}, \mathrm{R}^{1}\right.$ and $\left.\mathrm{R}^{2}=\mathrm{H}\right)$ reacts much better with sodium dodecyl thiolate (yield of $\mathrm{C}_{12} \mathrm{H}_{25} \mathrm{SCF}_{3}$ is $87 \%$ ) than the sulfur analogue (yield 47\%) [283,284].

On the whole $\mathrm{R}_{\mathrm{F}}$ onium compounds are powerful perfluoroalkylating agents $[33,281]$, however they are rather exotic reagents which require to be synthesized by multi-stage methods as illustrated in Scheme 74.

\section{Conclusion}

A summary of the known methods for the synthesis of aromatic and heterocyclic perfluoroalkyl sulfides are presented. These

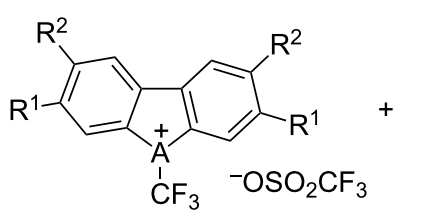<smiles>[N+]=[SH]c1ccccc1-c1ccccc1</smiles><smiles>COC(F)F</smiles><smiles>FC(F)(F)c1ccccc1-c1ccccc1</smiles>

\begin{tabular}{lcc}
$\mathrm{A}$ & $\mathrm{R}^{1}, \mathrm{R}^{2}$ & Yield \\
\hline $\mathrm{S}$ & $\mathrm{H}$ & $78 \%$ \\
$\mathrm{Se}$ & $\mathrm{H}$ & $89 \%$
\end{tabular}

$A=S$, Se, Te; $R^{1}, R^{2}=H$, Alk

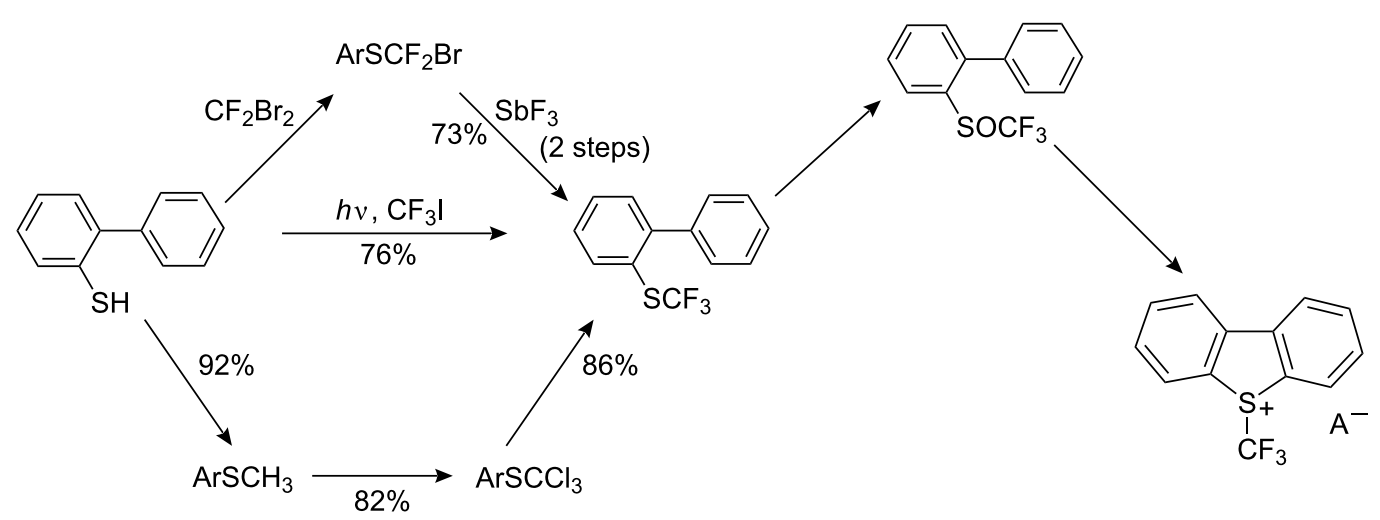


involve perfluoroalkylation of thiols by single electron transfer, nucleophilic and electrophilic methods. The variety of methods reflects the level of interest chemists have given to generating this class of fluorine containing organic compounds. As a class of compounds, perfluoroalkyl sulfides find increasing utility in agrochemical and pharmaceutical applications.

A concise review concerning the preparation of selectively fluorinated ethers, thioethers, amines and phosphines was published [285] during preparation of this manuscript.

\section{References}

1. Hansch, C.; Leo, A. Substituent constants for correlation analysis in chemistry and biology; Wiley: New York, 1979; p 339.

2. Becker, A. Inventory of industrial fluoro-biochemicals; Eyrolles: Paris, 1996; p 1041.

3. Leroux, F.; Jeschke, P.; Schlosser, M. Chem. Rev. 2005, 105, 827-856. doi:10.1021/cr040075b

4. Langlois, D. R.; Dillard, T.; Large, S.; Roques, N. Fluorinated Bio-Active Compounds in the Agricultural and Medical Fields; Brussels: Belgium, 1999.

Sept 13-15, 1999; Paper No 24.

5. Yagupolskii, L. M.; Maletina, I. I.; Petko, K. I.; Fedyuk, D. V. Fluorinated Bio-Active Compounds in the Agricultural and Medical Fields; Brussels: Belgium, 1999 September 13-15, 1999; Paper No 17.

6. Yagupolskii, L. M.; Maletina, I. I.; Petko, K. I.; Fedyuk, D. V.; Handrock, R.; Shavaran, S. S.; Klebanov, B. M.; Herzig, S. J. Fluorine Chem. 2001, 109, 87-94. doi:10.1016/S0022-1139(01)00382-7

7. SmithKline Beckman Corp. JP Patent 62,158,256, 1987. Chem. Abstr. 1988, 108, 131604w.

8. Ayerst, McKenna and Harrison, Inc. Canada Patent 1,248,127, 1989. Chem. Abstr. 1989, 111, 174666x.

9. Boiko, V. N.; Shchupak, G. M.; Karabanov, Yu. V. et al. USSR Patent 1,746,663, 1994. Chem. Abstr. 1995, 123, 308709x.

10. Dashevskaya, T. A.; Shalamay, A. S.; Shchupak, G. M.; Boiko, V. N., et at. USSR Patent 1,304,353, 1987. Otkrytiya, Izobret., 1987, 14, 255.

11. Gubnitskaya, E. S.; Boiko, V. N.; Kremlev, M. M. USSR Patent 1,839,443, 1993. Chem. Abstr. 1996, 124, 261367n.

12. Mizerski, A.; Gajadhur, A.; Pioro, S.; Ochal, Z. Chem. Environ. Res. 2002, 11, 47-61. Chem. Abstr. 2004, 140, 27628g.

13. Keil, S.; Wendler, W.; Glien, M.; Goerlitzer, J.; Chandross, K.; McGarry, D. G.; Merrill, J.; Bernardelli, P.; Ronan, B.; Terrier, C. Eur. Patent 1,586,573, 2005. Chem. Abstr. 2005, 143, 387044r.

14. Gaudilliere, B.; Jacobelli, H. WO Patent 2,004,321, 2003. Chem. Abstr. 2004, 140, 59649f.

15. Dalton, J. T.; Miller, D. D.; Yin, D.; He, Y. U.S. Patent 232,792, 2003. Chem. Abstr. 2004, 140, 41912b.

16. Dalton, J. T.; Miller, D. D.; He, Y.; Yin, D. U.S. Patent 14,975, 2004. Chem. Abstr. 2004, 140, 111132y.
17. Branstetter, B. J.; Breitenbucher, J. G.; Lebsack, A. D.; Liu, J.; Rech, J. C.; Xiao, W. U.S. Patent 156,599, 2009. Chem. Abstr. 2009, 151, 56868t.

18. Kompella, A. K.; Adibhatla, K. S.; Bhujanga, R.; Rachakonda, S.; Venkaiah, C. N. U.S. Patent 306,100, 2008. Chem. Abstr. 2009, 150, 35385x.

19. Yagupolskii, L. M. In Aromatic and Heterocyclic Compounds with Fluorine-Containing Substituents; Markovskii, L. N., Ed.; Naukova Dumka: Kiev, USSR, 1988; pp 98-126.

20. Dolbier, W. R., Jr. Chem. Rev. 1996, 1557-1584. doi:10.1021/cr941142c

21. Brace, N. O. J. Fluorine Chem. 1999, 93, 1-25. doi:10.1016/S0022-1139(98)00255-3

22. Yoshida, M.; Kamigata, N.; Sawada, H.; Nakayama, M. J. Fluorine Chem. 1990, 49, 1-20. doi:10.1016/S0022-1139(00)80359-0

23. Farnham, W. B. Chem. Rev. 1996, 96, 1633-1640. doi:10.1021/cr9411435

24. Uno, H.; Suzukib, H. Synlett 1993, 91-96. doi:10.1055/s-1993-22361

25. Burton, D. J.; Yang, Z.-Y. Tetrahedron 1992, 48, 189-275. doi:10.1016/S0040-4020(01)88139-4

26. Haas, A.; Niemann, U. Adv. Inorg. Chem. Radiochem. 1976, 18, 143.

27. Langlois, B. R.; Billard, T. Synthesis 2003, 185-194. doi:10.1055/s-2003-36812

28. Prakash, G. K. S.; Mandal, M. J. Fluorine Chem. 2001, 112, 123-131. doi:10.1016/S0022-1139(01)00477-8

29. Adams, D. J.; Clark, J. H.; Heath, P. A.; Hansen, L. B.; Sanders, V. C.; Tavener, S. J. J. Fluorine Chem. 2000, 101, 187-191. doi:10.1016/S0022-1139(99)00157-8

30. Singh, R. P.; Shreeve, J. M. Tetrahedron 2000, 56, 7613-7632. doi:10.1016/S0040-4020(00)00550-0

31. Furin, G. G. Zh. Org. Khim. 1997, 33, 1287-1319. Chem. Abstr. 1998, 129, 135686f. Russ. J. Org. Chem.1997, 33, 1209-1242.

32. Prakash, G. K. S.; Yudin, A. K. Chem. Rev. 1997, 97, 757-786. doi:10.1021/cr9408991

33. Umemoto, T. Chem. Rev. 1996, 96, 1757-1778. doi:10.1021/cr941149u

34. Huang, W.-Y. J. Fluorine Chem. 1992, 58, 1-8. doi:10.1016/S0022-1139(00)82787-6

35. Koshechko, V. G.; Kiprianova, L. A. Theor. Exp. Chem. 1999, 35, 17-34. doi:10.1007/BF02511124 In Russian; Chem. Abstr., 1999, 131, 304443y; Theor. Exp. Chem. 1999, 35, 18-36 (Eng. Ed.).

36. McClinton, M. A.; McClinton, D. A. Tetrahedron 1992, 48, 6555-6666. doi:10.1016/S0040-4020(01)80011-9

37. Barbor, A. K.; Belf, L. I.; Bekston, M. V. In Uspekhi Khimii Ftora; Sergeev, A. P., Ed.; Khimiya: Leningrad, 1970; Vol. 3-4, pp 90-193. Translation from Advances in Fluorine Chemistry; Stacey, M.; Tatlow, J. C.; Sharpe, A. G., Ed.; Butterworths Scientific Publication: London, 1963-1965; Vol. 3-4.

38. I. G. Farbenind. Patent D.R.P. 682,971, 1936. Blst. 1965, 6, III, 1009, 1033, 1034, 1038, 1067.

39. Muller, F.; Scherer, O.; Schumacher, W. Patent US 2,108,606, 1938. Chem. Abstr. 1938, 32, 2958.

40. I.G. Farbenindustrie. Fr. Patent 820,796, 1937. Zbl. 1938, 1, 1876.

41. Gregory, W. A. U.S. Patent 2,763,692, 1956 Chem. Abstr. 1957, 51, 4429c. 
42. Gregory, W. G. U.S. Patent 2,776,992, 1957 Chem. Abstr. 1957, 51, 15571c.

43. Buchanan, J. B.; Gregory, W. A. U.S. Patent 3,061,645, 1962. Chem. Abstr. 1963, 58, 10127d.

44. Nodiff, E. A.; Lipsehutz, S.; Craig, P. N.; Gordon, M. J. Org. Chem. 1960, 25, 60-65. doi:10.1021/jo01071a018

45. Yagupolskii, L. M.; Marenets, M. S. Zh. Obshch. Khim. 1956, 26, 101-107.

46. Yagupolskii, L. M.; Kiprianov, A. I. Zh. Obshch. Khim. 1952, 22, 2216-2220. Chem. Abstr. 1953, 47, 4771a.

47. Yagupolskii, L. M.; Marenets, M. S. Zh. Obshch. Khim. 1954, 24, 887-894.

Chem. Abstr. 1955, 49, 8172e; J. Gen. Chem. U.S.S.R. 1954, 24 , 885-891.

48. Yagupolskii, L. M.; Gandelsman, L. Z.; Trushanina, L. I. Ukr. Khim. Zh. 1965, 31, 1301-1305.

Chem. Abstr. 1966, 64, 14315g.

49. Yagupolskii, L. M.; Marenets, M. S. Zh. Obshch. Khim. 1959, 29 , 278-283.

Chem. Abstr. 1959, 53, $21765 i$.

50. Yagupolskii, L. M.; Gruz, B. E. Zh. Obshch. Khim. 1961, 31, 1315-1320.

Chem. Abstr. 1961, 55, $24720 \mathrm{i}$.

51. Gandelsman, L. Z.; Mostoslavskaya, E. I.; Yagupolskii, L. M. Ukr. Khim. Zh. 1975, 41, 61-66.

Chem. Abstr. 1975, 82, 172578d.

52. Yagupolskii, L. M.; Orda, V. V. Zh. Obshch. Khim. 1964, 34, 1979-1984.

Chem. Abstr. 1964, 61, 8217b.

53. Yagupolskii, L. M.; Boiko, V. N. Zh. Obshch. Khim. 1969, 39, 195-198.

Chem. Abstr. 1969, 70, 96324c.

54. Tohyama, Y.; Kanematsu, K.; PCT Int. Appl. WO 8,287, 2009. Chem. Abstr. 2009, 150, 144137p.

55. Yagupolskii, L. M.; D'yachenko, E. B.; Troitskaya, V. I. Ukr. Khim. Zh. 1961, 27, 77-79. Chem. Abstr. 1961, 55, 21029a.

56. Ponticello, G. S.; Hartman, R. D.; Lumma, W. C.; Baldwin, J. J. J. Org. Chem. 1979, 44, 3080-3082. doi:10.1021/jo01331a026

57. Knunyants, I. L.; Fokin, A. V. Izv. Akad. Nauk SSSR, Ser. Khim. 1952, 2, 261-267.

Chem. Abstr. 1953, 47, 3221b.

58. England, D. C.; Melby, L. R.; Dietrich, M. A.; Lindsey, R. V., Jr. J. Am. Chem. Soc. 1960, 82, 5116-5122. doi:10.1021/ja01504a026

59. Langlois, B.; Desbois, M. Actual. Chim. 1987, 5, 151-158. Chem. Abstr. 1988, 108, 149998n.

60. Wakselman, C.; Kaziz, C. J. Fluorine Chem. 1986, 33, 347-359.

61. Umemoto, T.; Ishihara, S. J. Fluorine Chem. 1998, 92, 181-187. doi:10.1016/S0022-1139(98)00276-0

62. Guo, Y.; Chen, Q.-Y. J. Fluorine Chem. 2000, 102, 105-109. doi:10.1016/S0022-1139(99)00228-6

63. Xing-ya, L.; He-qi, P.; Wei-min, F.; Xi-kui, J. J. Fluorine Chem. 1986 , 31, 213-229. doi:10.1016/S0022-1139(00)80535-7

64. Li, X.-y.; Jiang, X.-k.; Pan, H.-q.; Hu, J.-s.; Fu, W.-m. Pure Appl. Chem. 1987, 59, 1015-1020. doi:10.1351/pac198759081015

65. Suda, M.; Hino, C. Tetrahedron Lett. 1981, 22, 1997-2000. doi:10.1016/S0040-4039(01)92888-6
66. Siegrist, U.; Intermuehle, J.; Baumeister, P. Eur. Patent 168,344, 1986.

Chem. Abstr. 1986, 105, 60409.

67. Gassen, K. R.; Marhold, A. Ger. Patent 3,835,200, 1990. Chem. Abstr. 1990, 113, 211569g.

68. Jouen, C.; Lasne, M. C.; Pommelet, J. C. Tetrahedron Lett. 1996, 37 , 2413-2416. doi:10.1016/0040-4039(96)00186-4

69. Richert, H. Belg. Patent 624,397, 1963. Chem. Abstr. 1963, 59, 305.

70. Andreades, S.; Harris, J. F., Jr.; Sheppard, W. A. J. Org. Chem. 1964, 29, 898-900. doi:10.1021/jo01027a034

71. Lee, H.-S.; Geng, L.; Skotheim, T. WO Patent 96/29,753, 1996. U.S. Patent 5,538,812, 1996; Chem. Abstr. 1996, 125, 147119d.

72. Scribner, R. M. J. Org. Chem. 1966, 31, 3671-3682. doi:10.1021/jo01349a044

73. Scribner, R. M. U.S. Patent 3,381,020, 1968. Chem. Abstr. 1968, 69, 76945g.

74. Croft, T. S. Phosphorus Sulfur Relat. Elem. 1976, 2, 133-139. doi:10.1080/03086647608078938

75. Croft, T. S. Phosphorus Sulfur Relat. Elem. 1976, 2, 129-132. doi:10.1080/03086647608078937

76. Emeléus, H. J.; Nabi, S. N. J. Chem. Soc. 1960, 1103-1108.

77. Haas, A.; Hellwig, V. J. Fluorine Chem. 1975, 6, 521-532. doi:10.1016/S0022-1139(00)81691-7

78. Sheppard, W. A. J. Org. Chem. 1964, 29, 895-898. doi:10.1021/jo01027a033

79. Popov, V. I.; Kondranenko, N. V.; Haas, A. Ukr. Khim. Zh. 1983, 49, 861-863. Chem. Abstr. 1983, 99, 194535r.

80. Haas, A.; Niemann, U. Chem. Ber. 1977, 110, 67-77. doi:10.1002/cber.19771100108

81. Mirek, J.; Haas, A. J. Fluorine Chem. 1981, 19, 67-70. doi:10.1016/S0022-1139(00)85240-9

82. Gerstenberger, M. R. C.; Haas, A.; Liebig, F. J. Fluorine Chem. 1982, 19, 461-474. doi:10.1016/S0022-1139(00)83146-2

83. Croft, T. S.; McBrady, J. J. J. Heterocycl. Chem. 1975, 12, 845-849. doi:10.1002/jhet.5570120507 Chem. Abstr. 1976, 84, 43948s.

84. Gerstenberger, M. R. C.; Haas, A. J. Fluorine Chem. 1983, 23, 525-540. doi:10.1016/S0022-1139(00)85137-4

85. Haas, A.; Hellwig, V. Chem. Ber. 1976, 109, 2475-2484. doi:10.1002/cber.19761090715

86. Haas, A.; Niemann, U. J. Fluorine Chem. 1978, 11, 509-518. doi:10.1016/S0022-1139(00)82464-1

87. Dorn, S.; Eggenberg, P.; Gerstenberger, M. R. C.; Haas, A.; Niemann, U.; Zobrist, P. Helv. Chim. Acta 1979, 62, 1442-1450. doi:10.1002/hlca.19790620508

88. Clark, N. K. In Uspekhi Khimii Ftora; Sergeev, A. P., Ed.; Khimiya: Leningrad, 1970; Vol. 3-4, pp 43-48.

Translation from Advances in Fluorine Chemistry; Stacey, M.; Tatlow, J. C.; Sharpe, A. G., Ed.; Butterworths Scientific Publication: London, 1963-1965; Vol. 3-4.

89. Man, E. H.; Coffman, D. D.; Muetterties, E. L. J. Am. Chem. Soc. 1959, 81, 3575-3577. doi:10.1021/ja01523a023

90. Emeléus, H. J.; MacDuffie, D. E. J. Chem. Soc. 1961, 2597-2599.

91. Orda, V. V.; Yagupolskii, L. M.; Bystrov, V. F.; Stepanyants, A. U. Zh. Obshch. Khim. 1965, 35, 1628-1635.

Chem. Abstr. 1965, 63, 17861c.

92. Harris, J. F., Jr. J. Org. Chem. 1967, 32, 2063-2074. doi:10.1021/jo01282a004 
93. Yagupolskii, L. M.; Kondratenko, N. V.; Sambur, V. P. Synthesis 1975, 721-723. doi:10.1055/s-1975-23905

94. Kondratenko, N. V.; Kolomeytsev, A. A.; Popov, V. I.; Yagupolskii, L. M. Synthesis 1985, 667-669. doi:10.1055/s-1985-31301

95. Oksengendler, I. G.; Kondratenko, N. V.; Luk'yanets, E. A.; Yagupolskii, L. M. Zh. Org. Khim. 1978, 14, 1046-1051. Chem. Abstr. 1978, 89, 112289v.

96. Kolomeitsev, A. A.; Kondratenko, N. V.; Popov, V. I.; Yagupolskii, L. M. Zh. Org. Khim. 1983, 19, 2631-2632. Chem. Abstr. 1984, 100, 209281v.

97. Pazenok, S. V.; Kondratenko, N. V.; Popov, V. I.; Troitskaya, V. I.; Il'chenko, A. Ya.; Al'perovich, M. A.; Yagupolskii, L. M. Khim. Geterotsikl. Soedin. 1983, 1493-1499. Chem. Abstr. 1984, 100, 53186e.

98. Boiko, V. N.; Shchupak, G. M.; Yagupolskii, L. M. Zh. Org. Khim. 1980, 16, 995-1001. Chem. Abstr. 1980, 93, 167794u.

99. Yagupolskii, L. M.; Sambur, V. P.; Kondratenko, N. V. USSR Patent 462826, 1975.

Otkrytiya, Izobret., Prom. Obraztsy 1975, 9, 60; Chem. Abstr. 1975, $83,42811 \mathrm{j}$

100.Clark, J. H.; Jones, C. W.; Kybett, A. P.; McClinton, M. A.; Miller, J. M.; Bishop, D.; Blade, R. J. J. Fluorine Chem. 1990, 48, 249-253. doi:10.1016/S0022-1139(00)80437-6

101.Remy, D. C.; Rittle, K. E.; Hunt, C. A.; Freedman, M. B. J. Org. Chem. 1976, 41, 1644-1646. doi:10.1021/jo00871a037

102.Remy, D. C.; Freedman, M. B. U.S. Patent 4,020,169, 1977. Chem. Abstr. 1977, 87, 52939d.

103. Munavalli, S.; Rossman, D. I.; Rohrbaugh, D. K.; Ferguson, C. P.; Hsu, F.-L. Heteroat. Chem. 1992, 3, 189-192. doi:10.1002/hc.520030216

104.Munavalli, S.; Hassner, A.; Rossman, D. I.; Singh, S.; Rohrbaugh, D. K.; Ferguson, C. P. J. Fluorine Chem. 1995, 73, 7-11. doi:10.1016/0022-1139(94)03209-I

105. Kitazume, T.; Ishikawa, N. Bull. Chem. Soc. Jpn. 1975, 48, 361-362. doi:10.1246/bcsj.48.361

106.Chen, Q.-Y.; Duan, J.-X. Chem. Commun. 1993, 918-919.

107.Kolomeitsev, A.; Medebielle, M.; Kirsch, P.; Lork, E.; Roschenthaler, G.-V. J. Chem. Soc., Perkin Trans. 1 2000, 2183-2185.

108. Haas, A.; Klug, W. Chem. Ber. 1968, 101, 2609-2616. doi:10.1002/cber.19681010802

109.Dmowski, W.; Haas, A. Chimia 1985, 39, 185.

110.Dmowski, W.; Haas, A. J. Chem. Soc., Perkin Trans. 11987 , 2119-2124.

111.Dmowski, W.; Haas, A. J. Chem. Soc., Perkin Trans. 11988 , 1179-1181.

112.Petrova, T. D.; Platonov, V. E.; Shchegoleva, L. N.; Maksimov, A. M.; Haas, A.; Schelvis, M.; Lieb, M. J. Fluorine Chem. 1996, 79, 13-25. doi:10.1016/0022-1139(96)03465-3

113. Clark, J. H.; Tavener, S. J. J. Fluorine Chem. 1997, 85, 169-172. doi:10.1016/S0022-1139(97)00057-2

114.Tavener, S. J.; Adams, D. J.; Clark, J. H. J. Fluorine Chem. 1999, 95, 171-176. doi:10.1016/S0022-1139(99)00063-9

115. Tyrra, W.; Naumann, D.; Hoge, B.; Yagupolskii, Yu. L. J. Fluorine Chem. 2003, 119, 101-107. doi:10.1016/S0022-1139(02)00276-2

116. Jellinek, F. Proc. Chem. Soc., London 1959, 319-320.

117.Jellinek, F.; Lagowski, J. J. J. Chem. Soc. 1960, 810-814.
118.Adams, D. J.; Clark, J. H. J. Org. Chem. 2000, 65, 1456-1460. doi:10.1021/jo9915933

119. Haas, A.; Heuduk, H.; Monsé, C.; Yagupolskii, L. M. J. Fluorine Chem. 1999, 94, 195-198. doi:10.1016/S0022-1139(99)00014-7

120. Kondratenko, N. V.; Sambur, V. P. Ukr. Khim. Zh. 1975, 41, 516-519. Chem. Abstr. 1975, 83, 58321k.

121. Adams, D. J.; Goddard, A.; Clark, J. H.; Macquarrie, D. J. Chem. Commun. 2000, 987-988. doi:10.1039/b002560g

122.Banus, J.; Emeléus, H. J.; Haszeldine, R. N. J. Chem. Soc. 1951, 60-64. doi:10.1039/jr9510000060

123.Pierce, O. R.; McBee, E. T.; Judd, G. F. J. Am. Chem. Soc. 1954, 76, 474-478. doi:10.1021/ja01631a042

124.McBee, E. T.; Roberts, C. W.; Curtis, S. G. J. Am. Chem. Soc. 1955, 77, 6387-6390. doi:10.1021/ja01628a105

125. Chambers, R. D.; Musgrave, W. K. R.; Savory, J. J. Chem. Soc. 1962 1993-1999.

126. Johncock, P. J. Organomet. Chem. 1969, 19, 257-265. doi:10.1016/S0022-328X(00)85296-1

127.Lagowskii, J. J. Q. Rev., Chem. Soc. 1959, 13, 233-264.

128. Pouling, L. In Obschaya Khimiya; Karapet'yants, M. Kh., Ed.; Mir: Moscow, 1974; p 168.

Translation from Pouling, L. General Chemistry, W. H. Freeman and Co; San-Francisco, 1970.

129. Haley, B.; Haszeldine, R. N.; Hewitson, B.; Tipping, A. E. J. Chem. Soc., Perkin Trans. 1 1976, 525-532.

130. Haszeldine, R. N.; Higginbottom, B.; Rigby, R. B.; Tipping, A. E. J. Chem. Soc., Perkin Trans. 1 1972, 155-159.

131. Haszeldine, R. N.; Rigby, R. B.; Tipping, A. E. J. Chem. Soc., Perkin Trans. 1 1972, 159-161.

132. Huyser, E. S.; Bedard, E. J. Org. Chem. 1964, 29, 1588-1590. doi:10.1021/jo01029a077

133. Kimoto, H.; Fujii, S.; Cohen, L. A. J. Org. Chem. 1982, 47, 2867-2872. doi:10.1021/jo00136a010

134.Kornblum, N.; Davies, T. M.; Earl, G. W.; Holy, N. L.; Kerber, R. C.; Musser, M. T.; Snow, D. H. J. Am. Chem. Soc. 1967, 89, 725-727. doi:10.1021/ja00979a067

135.Kornblum, N.; Davies, T. M.; Earl, G. W.; Greene, G. S.; Holy, N. L.; Kerber, R. C.; Manthey, J. W.; Musser, M. T.; Snow, D. H. J. Am. Chem. Soc. 1967, 89, 5714-5715. doi:10.1021/ja00998a045

136. Kornblum, N.; Boyd, S. D.; Ono, N. J. Am. Chem. Soc. 1974, 96, 2580-2587. doi:10.1021/ja00815a043

137. Kornblum, N. Angew. Chem. 1975, 87, 797-808. doi:10.1002/ange.19750872204

138. Bunnett, J. F.; Kim, J. K. J. Am. Chem. Soc. 1970, 92, 7463-7464. doi:10.1021/ja00728a037

139. Bunnett, J. F.; Kim, J. K. J. Am. Chem. Soc. 1970, 92, 7464-7466. doi:10.1021/ja00728a038

140.Bunnett, J. F.; Creary, X. J. Org. Chem. 1974, 39, 3173-3174. doi:10.1021/jo00935a037

141.Bunnett, J. F.; Creary, X. J. Org. Chem. 1974, 39, 3611-3612. doi:10.1021/jo00938a044

142. Bunnett, J. F.; Creary, X. J. Org. Chem. 1975, 40, 3740-3743. doi:10.1021/jo00913a026

143. Boiko, V. N.; Shchupak, G. M.; Yagupolskii, L. M. Zh. Org. Khim. 1977, 13, 1057-1061. Chem. Abstr. 1977, 87, 134226h.

144.Popov, V. I.; Boiko, V. N.; Kondratenko, N. V.; Sambur, V. P.; Yagupolskii, L. M. Zh. Org. Khim. 1977, 13, 2135-2138. Chem. Abstr. 1978, 88, 104823d. 
145. Boiko, V. N.; Dashevskaya, T. A.; Shchupak, G. M.; Yagupolskii, L. M. Zh. Org. Khim. 1979, 15, 396-400.

Chem. Abstr. 1979, 91, 20439g.

146.Boiko, V. N.; Shchupak, G. M.; Popov, V. I.; Orlova, R. K.; Yagupol'skii, L. M. USSR Patent 687,067, 1979.

Chem. Abstr. 1980, 92, 22503t.

147.Voloshchuk, V. G.; Boiko, V. N.; Yagupolskii, L. M. Zh. Org. Khim. 1977, 13.

Chem. Abstr. 1978, 88, 6483y.

148.Kondratenko, N. V.; Popov, V. I.; Kolomeitsev, A. A.; Sadekov, I. D.; Minkin, V. I.; Yagupolskii, L. M. Zh. Org. Khim. 1979, 15, 1561-1562. Chem. Abstr. 1979, 91, 174948j.

149.Boiko, V. N.; Shchupak, G. M.; Kirii, N. V.; Kharchuk, A. N. USSR Patent 1,782,002, 2004.

150.Kondratenko, N. V.; Yurchenko, L. G.; Matyushecheva, G. I. Ukr. Khim. Zh. 1981, 47, 871-874. Chem. Abstr. 1981, 95, 186790x.

151.Kondratenko, N. V.; Kolomeitsev, A. A.; Popov, V. I.; Il'chenko, A. Ya. Zh. Obshch. Khim. 1983, 53, 2500-2505.

Chem. Abstr. 1984, 100, 50987f.

152.Kondratenko, N. V.; Popov, V. I.; Kolomeitsev, A. A.; Saenko, E. P.; Prezhdo, V. V.; Lutskii, A. E.; Yagupolskii, L. M. Zh. Org. Khim. 1980, 16, 1215-1221. Chem. Abstr. 1980, 93, 185545t.

153. Fugitt, R. B.; Luckenbaugh, R. W. Analogifremgangsmaate for fremstilling av terapeutisk virksomme 3-(p-alkylsulfonylfenyl)-oxa-zolidinon-derivater. NO Patent 156792, Aug 17, 1987.

154.Fedyuk, D. V.; Maletina, I. I.; Yagupolskii, L. M. Ukr. Khim. Zh. 1997, 63, 29-39. Chem. Abstr. 1999, 130, 182407w.

155. Fisher, I. P.; Homer, J. B.; Lossing, F. P. J. Am. Chem. Soc. 1965, 87, 957-960. doi:10.1021/ja01083a003

156. Rempel, G. D.; Borisov, Yu. A.; Rayevskii, N. I.; Igumnov, S. M.; Rozhkov, I. N. Izv. Akad. Nauk SSSR, Ser. Khim. 1990, 1064-1068. Chem. Abstr. 1990, 113, 96744w.

157.Gandel'sman, L. Z.; Boiko, V. N. Ukr. Khim. Zh. 1977, 43, 1224-1225. Chem. Abstr. 1978, 88, 89253x.

158.Boiko, V. N.; Kirii, N. V.; Shchupak, G. M. UA Patent 6205, 1994. Promyslova Vlasnist 1994, 8-I, 3.142; Chem. Abstr. 1996, 124 , 116859v.

159.Boiko, V. N.; Kirii, N. V.; Shchupak, G. M. RU Patent 2030397, 1995. Chem. Abstr. 1996, 124, 116859v.

160. Uneyama, K.; Kitagawa, K. Tetrahedron Lett. 1991, 32, 375-378. doi:10.1016/S0040-4039(00)92632-7

161. Uneyama, K.; Kanai, M. Tetrahedron Lett. 1991, 32, 7425-7426. doi:10.1016/0040-4039(91)80124-O

162.Boiko, V. N.; Shchupak, G. M.; Yagupolskii, L. M. Zh. Org. Khim. 1985, 21, 1470-1477. Chem. Abstr. 1986, 104, $206815 u$.

163.Boiko, V. N.; Shchupak, G. M.; Ignat'ev, N. V.; Yagupolskii, L. M. Zh. Org. Khim. 1979, 15, 1245-1253. Chem. Abstr. 1979, 91, 157378 f.

164. Havinga, E.; Kronenberg, M. E. Pure Appl.Chem. 1968, 16, 137-152. doi:10.1351/pac196816010137

165. Yavorskii, A. E.; Stetsenko, A. V.; Gogoman, I. V.; Boiko, V. N. Khim. Geterotsikl. Soedin. 1988, 632-636. Chem. Abstr. 1989, 110, 114751r.

166. Laser, E. S.; Matteo, M. R.; Possanza, G. J. J. Med. Chem. 1987, 30, 726-729. doi:10.1021/jm00387a026
167.Popov, V. I.; Boiko, V. N.; Yagupolskii, L. M. J. Fluorine Chem. 1982, 21, 365-369. doi:10.1016/S0022-1139(00)81521-3

168. Huebl, D.; Puttner, R.; Richter, E.; Pieroh, E.-A. 2-Imino-1,3-dithietanes, their preparation and their use as pesticides. DE Patent 3703213, Aug 11, 1988. Chem. Abstr. 1988, 109, 170410v.

169. Chen, Q.-Y.; Chen, M.-J. J. Fluorine Chem. 1991, 51, 21-32. doi:10.1016/S0022-1139(00)80303-6

170.Rico, I.; Cantacuzene, D.; Wakselman, C. J. Org. Chem. 1983, 48, 1979-1982. doi:10.1021/jo00160a007

171.Rico, I.; Wakselman, C. J. Fluorine Chem. 1982, 20, 759-764. doi:10.1016/S0022-1139(00)81443-8

172.Patric, S. In Uspekhy Khim. Ftora; Sergeev, A. P., Ed.; Khimia: Moscow, 1964; Vol. I-II, p 360. Translation from Advances in Fluorine Chemistry, Butterworths Science Publ.: London, U.K., 1960-1961; Vol. I-II.

173. Andrieux, C. P.; Gelis, L.; Medebielle, M.; Pinson, J.; Saveant, J. M. J. Am. Chem. Soc. 1990, 112, 3509-3520. doi:10.1021/ja00165a040

174. Ignat'ev, N. V.; Boiko, V. N.; Yagupolskii, L. M. Zh. Org. Khim. 1985, 21, 653.

Chem. Abstr. 1985, 103, 141549 t.

175. Ignat'ev, N. V.; Boiko, V. N.; Yagupolskii, L. M. USSR Patent 1167181, 1985.

Otkrytiya, Izobret., Prom. Obraztsy 1985, 26, 108.

176.Wakselman, C.; Tordeux, M. J. Chem. Soc., Chem. Commun. 1984, 793-794. doi:10.1039/C39840000793

177.Tordeux, M.; Wakselman, C. Procede de preparation de perhalogenoalkylthioethers. FR Patent 2540108, Dec 27, 1985. Chem.Abstr. 1985, 102, 45480x.

178.Wakselman, C.; Tordeux, M. J. Org. Chem. 1985, 50, 4047-4051. doi:10.1021/jo00221a017

179.Boiko, V. N.; Shchupak, G. M.; Kirij, N. V. Ukr. Khim. Zh. 2001, 67, 51-54.

180.Bunnett, J. F.; Scamehorn, R. G.; Traber, R. P. J. Org. Chem. 1976, 41, 3677-3682. doi:10.1021/jo00885a005

181. Koshechko, V. G.; Kiprianova, L. A.; Fileleeva, L. I.; Boiko, V. N. In Abstracts of Papers, 6th Vsesoyuznaya konferentsiya po organicheskoi khimii, Oct 10-14, 1988; Chernovtsy, Ukraine; p 182.

182. Ignat'ev, N. V.; Datsenko, S. D.; Yagupolskii, L. M. Zh. Org. Khim. 1991, 27, 905-910. Chem. Abstr. 1992, 116, 58861m.

183. Datsenko, S. D.; Ignat'ev, N. V.; Yagupolskii, L. M. Elektrokhimiya 1991, 27, 1674-1676. Chem. Abstr. 1992, 116, 115486 u.

184. Medebielle, M.; Pinson, J.; Saveant, J. M. J. Am. Chem. Soc. 1991, 113, 6872-6879. doi:10.1021/ja00018a025

185. Kitazume, T.; Ikeya, T. J. Org. Chem. 1988, 53, 2349-2350. doi:10.1021/jo00245a040

186. Koshechko, V. G.; Kiprianova, L. A.; Fileleeva, L. I. Tetrahedron Lett. 1992, 33, 6677-6678. doi:10.1016/S0040-4039(00)61016-X

187.Petrov, V. A. Tetrahedron Lett. 2001, 42, 3267-3269. doi:10.1016/S0040-4039(01)00447-6

188. Feiring, A. E. J. Fluorine Chem. 1984, 24, 191-203. doi:10.1016/S0022-1139(00)85203-3

189. Boiko, V. N.; Shchupak, G. M. J. Fluorine Chem. 1994, 69, 207-212. doi:10.1016/0022-1139(94)03132-0

190.Wakselman, C.; Tordeux, M. Bull. Soc. Chim. Fr. 1986, 868-870.

191.Tordeux, M.; Langlois, B.; Wakselman, C. J. Org. Chem. 1989, 54, 2452-2453. doi:10.1021/jo00271a041 
192. Tordeux, M.; Langlois, B.; Wakselman, C. J. Chem. Soc., Perkin Trans. 1 1990, 2293-2299. doi:10.1039/P19900002293

193. Clavel, J. L.; Langlois, B.; Nantermet, R.; Tordeux, M.; Wakselman, C. Process for the preparation of perhalogen alkyl thio ethers. EU Patent 374061, June 20, 1990. Chem.Abstr. 1991, 114, 5483s

194.Folest, J.-C.; Nédélec, J.-Y.; Périchon, J. Synth. Commun. 1988, 18 1491-1494. doi:10.1080/00397918808081305

195.Andrieux, C. P.; Gelis, L.; Saveant, J. M. J. Am. Chem. Soc. 1990 , 112, 786-791. doi:10.1021/ja00158a044

196.Wakselman, C.; Tordeux, M.; Clavel, J.-L.; Langlois, B. J. Chem. Soc., Chem. Commun. 1991, 993-994. doi:10.1039/C39910000993

197. Clavel, J.-L.; Langlois, B.; Nantermet, R.; Tordeux, M.; Wakselman, C. J. Chem. Soc., Perkin Trans. 1 1992, 3371-3375. doi:10.1039/P19920003371

198. Magnier, E.; Vit, E.; Wakselman, C. Synlett 2001, 1260-1262. doi:10.1055/s-2001-16050

199. Koshechko, V. G.; Kiprianova, L. A.; Fileleeva, L. I.; Rozhkova, Z. Z. Teor. Eksp. Khim. 1993, 29, 244-249. Chem. Abstr. 1994, 121, $120151 \mathrm{p}$.

200.Koshechko, V. G.; Kiprianova, L. A.; Fileleeva, L. I.; Rozhkova, Z. Z. J. Fluorine Chem. 1995, 70, 277-278. doi:10.1016/0022-1139(94)03128-M

201.Joglekar, B.; Miyake, T.; Kawase, R.; Shibata, K.; Muramatsu, H.; Matsui, M. J. Fluorine Chem. 1995, 74, 123-126. doi:10.1016/0022-1139(95)03261-B

202. Koshechko, V. G.; Kiprianova, L. A.; Fileleeva, L. I.; Tsanov, K. G. J. Fluorine Chem. 1999, 96, 163-166. doi:10.1016/S0022-1139(99)00069-X

203. Koshechko, V. G.; Kiprianova, L. A.; Fileleeva, L. I.; Kalinina, L. I. J. Fluorine Chem. 2007, 128, 1376-1378. doi:10.1016/j.jluchem.2007.06.006

204.Feiring, A. E.; Wonchoba, E. R.; Arthur, S. D. J. Polym. Sci. Polym. Chem. Ed. 1990, 28, 2809-2819. doi:10.1002/pola.1990.080281018

205.Su, D.; Chen, Q.; Zhu, R. Youji Huaxue 1986, 112-120. Chem. Abstr. 1986, 105, 225915p.

206. Nishi, M.; Narita, K. Production of aminophenyl alkyl sulfide. JP Patent 10291973, Nov 4, 1998. Chem.Abstr. 1999, 130, 3685r.

207.Ward, W.; Sicree, S.; Chen, B.; Tamborski, C. J. Fluorine Chem. 1995, 73, 73-77. doi:10.1016/0022-1139(94)03200-J

208.Wakselman, C. J. Fluorine Chem. 1992, 59, 367-378. doi:10.1016/S0022-1139(00)80331-0

209. Rozhkov, I. N.; Igumnov, S. M.; Becker, G. Ya.; Pletn'ev, S. I. Izv. Akad. Nauk SSSR, Ser. Khim. 1989, 2222-2224. Chem. Abstr. 1990, 112, 76153d.

210.Kobayashi, Y.; Kumadaki, I.; Ohsawa, A.; Murakami, S.-I.; Nakano, T. Chem. Pharm. Bull. 1978, 26, 1247-1249.

211. Haszeldine, R. N.; Rigby, R. B.; Tipping, A. E. J. Chem. Soc., Perkin Trans. 1 1972, 2180-2182. doi:10.1039/P19720002180

212.Sagami Chemical Research Center. JP Patent 81122344, 1981. Chem. Abstr. 1982, 96, 85048b.

213. Umemoto, T.; Miyano, O. Tetrahedron Lett. 1982, 23, 3929-3930. doi:10.1016/S0040-4039(00)87745-X

214. Umemoto, T.; Ando, A. Bull. Chem. Soc. Jpn. 1986, 59, 447-452. doi:10.1246/bcsj. 59.447
215.Sekiya, A.; Umemoto, T. Chem. Lett. 1982, 11, 1519-1520. doi:10.1246/cl.1982.1519

216.Barton, D. H. R.; Lacher, B.; Zard, S. Z. Tetrahedron 1986, 42 , 2325-2328. doi:10.1016/S0040-4020(01)90613-1

217.Barton, D. H. R.; Lacher, B.; Zard, S. Z. Tetrahedron 1987, 43, 4321-4328. doi:10.1016/S0040-4020(01)90307-2

218. Billard, T.; Roques, N.; Langlois, B. R. J. Org. Chem. 1999, 64, 3813-3820. doi:10.1021/jo980649a

219. Billard, T.; Roques, N.; Langlois, B. R. Tetrahedron Lett. 2000, 41, 3069-3072. doi:10.1016/S0040-4039(00)00337-3

220. Tanabe, Y.; Matsuo, N.; Ohno, N. J. Org. Chem. 1988, 53, 4582-4585. doi:10.1021/jo00254a033

221.Sipyagin, A. M.; Pomytkin, I. A.; Pal'tsun, S. V.; Aleinikov, N. N.; Kartsev, V. G. Dokl. Akad. Nauk SSSR 1990, 311, 1137-1139. Chem. Abstr. 1990, 113, 152212k.

222. Sipyagin, A. M.; Pomytkin, I. A.; Pal'tsun, S. V.; Aleinikov, N. N. Khim. Geterotsikl. Soedin. 1994, 58-62. Chem. Abstr. 1995, 122, 31274j.

223.Sipyagin, A. M.; Enshov, V. S.; Boiko, G. N.; Lebedev, A. T.; Karakhanova, N. K. Khim. Geterotsikl. Soedin. 2003, 1698-1706. In Russian.

224.Sipyagin, A. M.; Efremov, I. V.; Pomytkin, I. A.; Kashtanov, S. A.; Aleinikov, N. N. Khim. Geterotsikl. Soedin. 1994, 1291-1292. Chem. Abstr. 1995, 122, 239503r.

225. Enshov, V. S.; Kashtanov, S. A.; Efremov, I. V.; Pomytkin, I. A.; Sipyagin, A. M. Khim. Geterotsikl. Soedin. 1995, 1703. Chem. Abstr. 1996, 125, 33451a.

226. Sipyagin, A. M.; Enshov, V. S.; Lebedev, A. T.; Karakhanova, N. K. Khim. Geterotsikl. Soedin. 2003, 1173-1180. In Russian.

227.Sipyagin, A. M.; Enshov, V. S.; Kashtanov, S. A.; Treshcher, D. S. Khim. Geterotsikl. Soedin. 2002, 1559-1565. In Russian.

228. Clavel, J.-L.; Langlois, B.; Laurent, E.; Roidot, N. Phosphorus, Sulfur Silicon Relat. Elem. 1991, 59, 169-172. doi:10.1080/10426509108045716

229. Clavel, J.-L.; Laurent, E.; Langlois, B.; Roidot, N. Reagent and process for the perfluoroalkylation of nucleophilic substrates by sodium perfluoroalkanesulfinates in an oxidising medium. EP Patent 458684, May 17, 1991. Chem. Abstr. 1992, 116, 127821n.

230. Kirij, N. V.; Pasenok, S. V.; Yagupolskii, Yu. L.; Tyrra, W.; Naumann, D. J. Fluorine Chem. 2000, 106, 217-221. doi:10.1016/S0022-1139(00)00339-0

231.Kondratenko, N. V.; Popov, V. I.; Yurchenko, L. G.; Kolomeitsev, A. A.; Yagupolskii, L. M. Zh. Org. Khim. 1978, 14, 1914-1917.

Chem. Abstr. 1979, 90, 54603a.

232.Zeifman, Yu. V.; Lantseva, L. T.; Knunyants, I. L. Izv. Akad. Nauk SSSR, Ser. Khim. 1978, 2640-2643. Chem. Abstr. 1979, 91, 56281p.

233. Suzuki, H.; Satake, H.; Uno, H.; Shimizu, H. Bull. Chem. Soc. Jpn. 1987, 60, 4471-4473. doi:10.1246/bcsj.60.4471

234.Suzuki, H.; Uno, H.; Shimizu, H.; Nemoto, F. Production of perfluoroalkylaryl sulfide. JP Patent 6354357, March 8, 1988. Chem. Abstr. 1988, 109, 73127a.

235.Zeifman, Yu. V.; Lantseva, L. T.; Knunyants, I. L. Izv. Akad. Nauk SSSR, Ser. Khim. 1978, 1229. Chem. Abstr. 1978, 89, 146381j. 
236.Zeifman, Yu. V.; Lantseva, L. T. Izv. Akad. Nauk SSSR, Ser. Khim. 1980, 1102-1106.

Chem. Abstr. 1980, 93, 113882c.

237.Nguyen, T.; Rubinstein, M.; Wakselman, C. J. Org. Chem. 1981, 46, 1938-1940. doi:10.1021/jo00322a047

238. Tordeux, M.; Francese, C.; Wakselman, C. J. Fluorine Chem. 1989, 43, 27-34. doi:10.1016/S0022-1139(00)81634-6

239.Pooput, C.; Médebielle, M.; Dolbier, W. R., Jr.. Org. Lett. 2004, 6, 301-303. doi:10.1021/ol036303q

240.Pooput, C.; Dolbier, W. R., Jr..; Médebielle, M. J. Org. Chem. 2006, 71, 3564-3568. doi:10.1021/jo060250j

241.Billard, T.; Langlois, B. R. Tetrahedron Lett. 1996, 37, 6865-6868. doi:10.1016/0040-4039(96)01530-4

242. Quiclet-Sire, B.; Saicic, R. N.; Zard, S. Z. Tetrahedron Lett. 1996, 37, 9057-9058. doi:10.1016/S0040-4039(96)02127-2

243. Russell, J.; Roques, N. Tetrahedron 1998, 54, 13771-13782. doi:10.1016/S0040-4020(98)00846-1

244.Large, S.; Roques, N.; Langlois, B. R. J. Org. Chem. 2000, 65, 8848-8856. doi:10.1021/jo000150s

245. Roques, N. J. Fluorine Chem. 2001, 107, 311-314. doi:10.1016/S0022-1139(00)00374-2

246. Blond, G.; Billard, T.; Langlois, B. R. Tetrahedron Lett. 2001, 42, 2473-2475. doi:10.1016/S0040-4039(01)00225-8

247.Inschauspe, D.; Sortais, J.-B.; Billard, T.; Langlois, B. R. Synlett 2003, 233-235. doi:10.1055/s-2003-36788

248.Prakash, G. K. S.; Hu, J.; Olah, G. A. Org. Lett. 2003, 5, 3253-3256. doi:10.1021/ol035045u

249. Popkova, V. Y.; Marhold, A. Process for the preparation of perfluoalkylaryl sulfides and perfluoroalkylaryl sulfides per se. EP Patent 962450, Dec 8, 1999. Chem. Abstr. 2000, 132, 3248s.

250. Hudlicky, M.; Pavlath, A. E., Eds. Chemistry of organic fluorine compounds II. A Critical Review (ACS Monograph 187); American Chemical Society: Washington, 1995; p 905.

251.Lovelace, A. M.; Rausch, D. A.; Postelnek, M. In Aliphaticheskie fluorine-containing compounds; Knunyants, I. L., Ed.; Inostrannaya Literatura: Moscow, 1961; p 109.

Translation from Aliphatic Fluorine compounds ACS Monograph Series: N.Y., London.

252.Emeléus, H. J.; Haszeldine, R. N. J. Chem. Soc. 1949, 2953-2956. doi:10.1039/JR9490002953

253. Haszeldine, R. N. J. Chem. Soc. 1954, 1273-1279. doi:10.1039/JR9540001273

254.McBee, E. T.; Battershell, R. D.; Braendlin, H. P. J. Org. Chem. 1963, 28, 1131-1133. doi:10.1021/jo01039a504

255.Emeléus, H. J.; Haszeldine, R. N. J. Chem. Soc. 1949, 2948-2952. doi:10.1039/JR9490002948

256. Burton, D. J.; Hahnfeld, J. L. J. Org. Chem. 1977, 42, 828-831. doi:10.1021/jo00425a012

257.Schlosser, M.; Heinz, G.; Chau, L. V. Chem. Ber. 1971, 104, 1921-1933. doi:10.1002/cber.19711040632

258.Schlosser, M.; Heinz, G. Chem. Ber. 1971, 104, 1934-1941. doi:10.1002/cber.19711040633

259. Chang, Y.; Cai, C. J. Fluorine Chem. 2005, 126, 937-940. doi:10.1016/j.jluchem.2005.04.012

260.Folléas, B.; Marek, I.; Normant, J.-F.; Saint-Jalmes, L. Tetrahedron 2000, 56, 275-283. doi:10.1016/S0040-4020(99)00951-5

261.Shono, T.; Ishifune, M.; Okada, T.; Kashimura, S. J. Org. Chem. 1991, 56, 2-4. doi:10.1021/jo00001a002
262. Roques, N.; Russell, J. WO Appl. 9719038, 1997. Chem. Abstr. 1997, 127, 50384q.

263. Folléas, B.; Marek, I.; Normant, J.-F.; Saint-Jalmes, L. Tetrahedron Lett. 1998, 39, 2973-2976. doi:10.1016/S0040-4039(98)00391-8

264.Billard, T.; Langlois, B. R.; Blond, G. Eur. J. Org. Chem. 2001, 1467-1471. doi:10.1002/1099-0690(200104)2001:8<1467::AID-EJOC1467>3.0.C O;2-A

265. Olah, G. A.; Chambers, R. D.; Prakash, G. K. S., Eds. Synthetic Fluorine Chemistry; Wiley-Interscience: New York, 1992; p 402.

266. Ruppert, I.; Schlich, K.; Volbach, W. Tetrahedron Lett. 1984, 25 , 2195-2198. doi:10.1016/S0040-4039(01)80208-2

267. Kolomeitsev, A. A.; Movchun, V. N.; Kondratenko, N. V.; Yagupolskii, Yu. L. Synthesis 1990, 1151-1152. doi:10.1055/s-1990-27121

268. Patel, N. R.; Kirchmeier, R. L. Inorg Chem. 1992, 31, 2537-2540. doi:10.1021/ic00038a042

269. Singh, R. P.; Cao, G.; Kirchmeier, R. L.; Shreeve, J. M. J. Org. Chem. 1999, 64, 2873-2876. doi:10.1021/j0982494c

270. Movchun, V. N.; Kolomeitsev, A. A.; Yagupolskii, Yu. L. J. Fluorine Chem. 1995, 70, 255-257. doi:10.1016/0022-1139(94)03124-I

271.Billard, T.; Large, S.; Langlois, B. R. Tetrahedron Lett. 1997, 38, 65-68. doi:10.1016/S0040-4039(96)02216-2

272.Shein, S. M.; Krasnosel'skaya, M. I.; Boiko, V. N. Zh. Obshch. Khim. 1966, 36, 2141-2147. Chem. Abstr. 1967, 66, 94446n.

273. Steensma, R. W.; Galabi, S.; Tagat, J. R.; McCombie, S. W. Tetrahedron Lett. 2001, 42, 2281-2283. doi:10.1016/S0040-4039(01)00164-2

274.Barrera, M. D.; Cheburkov, Y.; Lamanna, W. M. J. Fluorine Chem. 2002, 117, 13-16. doi:10.1016/S0022-1139(02)00170-7

275. Yagupolskii, L. M.; Maletina, I. I.; Kondratenko, N. V.; Orda, V. V. Synthesis. 1978, 835-837.

276. Yagupolskii, L. M.; Mironova, A. A.; Maletina, I. I. Zh. Org. Khim. 1980, 16, 232-233. Chem. Abstr. 1980, 93, 26005a.

277.Umemoto, T.; Kuriu, Y. Chem. Lett. 1982, 65-66. doi:10.1246/cl.1982.65

278. Eisenberger, P.; Gischig, S.; Togni, A. Chem.-Eur. J. 2006, 12, 2579-2586. doi:10.1002/chem.200501052

279. Kieltsch, I.; Eisenberger, P.; Togni, A. Angew. Chem., Int. Ed. 2007, 46, 754-757. doi:10.1002/anie.200603497

280. Yagupolskii, L. M.; Kondratenko, N. V.; Timofeeva, G. N. Zh. Org. Khim. 1984, 20, 115-118. Chem. Abstr. 1984, 100, 191494e.

281. Yang, J.-J.; Kirchmeier, R. L.; Shreeve, J. M. J. Org. Chem. 1998, 63, 2656-2660. doi:10.1021/jo972213।

282. Magnier, E.; Blazejewski, J.-C.; Tordeux, M.; Wakselman, C. Angew. Chem. 2006, 118, 1301-1304. doi:10.1002/ange.200503776

283. Umemoto, T.; Ishihara, S. J. Am. Chem. Soc. 1993, 115, 2156-2164. doi:10.1021/ja00059a009

284. Umemoto, N.; Ishihara, S. Tetrahedron Lett. 1990, 31, 3579-3582. doi:10.1016/S0040-4039(00)94447-2

285. Manteau, B.; Pazenok, S.; Vors, J. P.; Leroux, F. R. J. Fluorine Chem. 2010, 131, 140-158. doi:10.1016/j.jfluchem.2009.09.009 


\section{License and Terms}

This is an Open Access article under the terms of the Creative Commons Attribution License

(http://creativecommons.org/licenses/by/2.0), which permits unrestricted use, distribution, and reproduction in any medium, provided the original work is properly cited.

The license is subject to the Beilstein Journal of Organic Chemistry terms and conditions:

(http://www.beilstein-journals.org/bjoc)

The definitive version of this article is the electronic one which can be found at:

doi:10.3762/bjoc.6.88 